\title{
SÄÄ- JA ILMASTOTIEDOT SEKÄ UUDET PALVELUT AUTTAVAT METSÄBIOTALOUTTA SOPEUTUMAAN ILMASTONMUUTOKSEEN
}

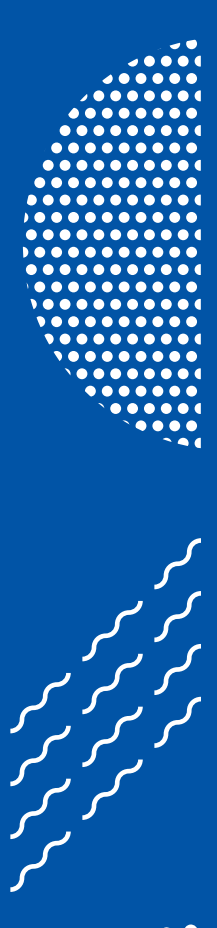

ARI VENÄLÄINEN

SANNA LUHTALA MIKKO LAAPAS OTTO HYVÄRINEN HILPPA GREGOW MIKKO STRAHLENDORFF MIKKO PELTONIEMI SUSANNE SUVANTO SEPPO NEVALAINEN HELI PELTOLA LEENA A. LESKINEN HANNU ALA-HONKOLA

YRJÖ NISKANEN ASKO POIKELA MARJO MAIDELL PAULA HORNE OLLI-PEKKA RUUSKANEN 


\section{RAPORTTEJA \\ RAPPORTER \\ REPORTS}

No. 2021:1

\section{SÄÄ- JA ILMASTOTIEDOT SEKÄ UUDET PALVELUT AUTTAVAT METSÄBIOTALOUTTA SOPEUTUMAAN ILMASTONMUUTOKSEEN}

Ari Venäläinen, Sanna Luhtala, Mikko Laapas, Otto Hyvärinen, Hilppa Gregow, Mikko Strahlendorff (Ilmatieteen laitos)

Mikko Peltoniemi, Susanne Suvanto, Seppo Nevalainen (Luonnonvarakeskus)

Heli Peltola (Itä-Suomen yliopisto, Metsätieteiden osasto)

Leena A. Leskinen, Hannu Ala-Honkola, Yrjö Niskanen (Suomen Metsäkeskus)

Asko Poikela (Metsäteho Oy)

Marjo Maidell, Paula Horne, Olli-Pekka Ruuskanen (Pellervon taloustutkimus)

Ilmatieteen laitos

Meteorologiska institutet

Finnish Meteorological Institute

Helsinki 2021 
ISBN 978-952-336-132-4 (nide)

ISBN 978-952-336-131-7 (pdf)

ISSN 0782-6079

Edita Prima Oy

Helsinki, 2021 


\begin{tabular}{|c|c|c|}
\hline \multirow{2}{*}{\multicolumn{2}{|c|}{$\begin{array}{l}\text { Julkaisija } \\
\text { Ilmatieteen laitos } \\
\text { Erik Palménin aukio 1, PL } 503 \\
00101 \text { Helsinki }\end{array}$}} & \\
\hline & & \\
\hline \multicolumn{2}{|c|}{$\begin{array}{l}\text { Tekijät: Ari Venäläinen, Sanna Luhtala, Mikko Laapas, Otto Hyvärinen } \\
\text { Hilppa Gregow, Mikko Strahlendorff, Mikko Peltoniemi, Susanne } \\
\text { Suvanto, Seppo Nevalainen, Heli Peltola, Leena A. Leskinen, Hannu Ala- } \\
\text { Honkola, Yrjö Niskanen, Asko Poikela, Marjo Maidell, Paula Horne, Olli- } \\
\text { Pekka Ruuskanen }\end{array}$} & \\
\hline \multicolumn{3}{|c|}{$\begin{array}{l}\text { Nimeke: Sää- ja ilmastotiedot sekä uudet palvelut auttavat metsäbiotaloutta sopeutumaan } \\
\text { ilmastonmuutokseen }\end{array}$} \\
\hline $\begin{array}{l}\text { Ilmastonmuutoksen seuraul } \\
\text { tehokkaita sopeutumistoimia } \\
\text { tukevassa Säätyö-hankkeess } \\
\text { kehittäneet metsätaloutta hy } \\
\text { ilmastopalveluiden tarvetta. I } \\
\text { Säätyö-hankkeessa kehitetti } \\
\text { esitetään säätietojen avulla } \\
\text { Hankkeessa myös testattiin } \\
\text { Säätyön ennustepalvelua si } \\
\text { yhteistyöhanke nimeltään } \\
\text { hyödyntää maaston kantavuı } \\
\text { ennusteita. } \\
\text { Itä-Suomen yliopiston Me } \\
\text { tuulituhoriskityökalun testive } \\
\text { tarvittavia tuulennopeuksia. T } \\
\text { myös mahdollisuutta paikaı } \\
\text { Menetelmänä käytettiin sääas } \\
\text { analysoitiin kesällä ja syksyl } \\
\text { laatijat pitivät tehtyjä kartta-a } \\
\text { Lumen kertymää puiden c } \\
\text { kosteuden ja tuulen nopeudeI } \\
\text { siten, että kertyneen lumiku } \\
\text { korkeusvaihtelut. Tehdyn v } \\
\text { lumikuormaolosuhteissa (tal } \\
\text { merkitys. Vertailun mukaan t } \\
\text { Hankkeessa kartoitettiin ha } \\
\text { edellytyksiä ja kehitysmahdo } \\
\text { käyttömahdollisuuksia ja käy } \\
\text { ennakoivaa metsänhoitoa, jo } \\
\text { mahdollistama entistä ajantas } \\
\text { toteutusta ja puuvarastojen l } \\
\text { mukaan tiedon käyttöönottoo } \\
\text { tietotuotteista ei oltu tällä he } \\
\text { tietotuotteiden kehitysehdotul }\end{array}$ & $\begin{array}{l}\text { metsiin kohdistuvat sään aiheu } \\
\text { a- ja metsätalousministeriön rah } \\
\text { lemme tehneet yhteenvedon sc } \\
\text { täviä sää- ja ilmastopalveluita s } \\
\text { si olemme kirjanneet keskeisiä so } \\
\text { taan pintakerroksen kosteutta ja } \\
\text { tettu analyysi vallitsevasta tilar } \\
\text { en kolmen kuukauden päähän yl } \\
\text { hyödyntää ja täydentää toine } \\
\text { resterSeasons (https://harvesters } \\
\text { suhteiden arvioinnissa pitkiä, no } \\
\text { eteiden osastolla kehitettiin Iln } \\
\text { minkä avulla voidaan laskea p } \\
\text { lu soveltuu tällä hetkellä vain tutk } \\
\text { pahimmat tuulituhoalueet välit } \\
\text { la tehtävien tuulihavaintojen alue } \\
\text { O20 metsätuhoja aiheuttaneita my } \\
\text { ysejä havainnollisina ja hyödyllis } \\
\text { e, voidaan mallintaa säätietojen }\end{array}$ & $\begin{array}{l}\text { amat riskit kasvavat, ja siksi tarvitaan } \\
\text { ittamassa metsätalouden sopeutumista } \\
\text { eutumista auttavista tietoaineistoista, } \\
\text { ä kartoittaneet metsätalouden sää- ja } \\
\text { eutumista edistäviä jatkokehitystoimia. } \\
\text { antavuutta kuvaava palvelutuote, jossa } \\
\text { esta sekä } 10 \text { vuorokauden ennuste. } \\
\text { tyvien ennusteiden käyttökelpoisuutta. } \\
\text { Ilmatieteen laitoksen ja Metsätehon } \\
\text { sons.com/) HarvesterSeasons-palvelu } \\
\text { l kuuden kuukauden päähän ulottuvia } \\
\text { tieteen laitoksen kanssa yhteistyössä } \\
\text { ston tuulituhoon (puiden kaatuminen) } \\
\text { akäyttöön. Säätyö-hankkeessa testattiin } \\
\text { mästi tapahtuneen myrskyn jälkeen. } \\
\text { lista interpolointia. Menetelmän avulla } \\
\text { kyjä. Myrskyn jälkeisen tilannekuvan } \\
\text { ä. } \\
\text { kuten sademäärän, lämpötilan, ilman } \\
\text { skin arviointimallia kehitetiin edelleen } \\
\text { puuston ominaisuudet sekä maaston } \\
\text { jiden merkitys kasvoi äärimmäisissä } \\
\text { lestaan korostui bioottisten tekijöiden } \\
\text { iän testatulla mallilla hyvin. } \\
\text { l käyttökohteita, hyötyjä, käyttöönoton } \\
\text { lle ja -palveluille nähtiin monipuolisia } \\
\text { eiden avulla olisi mahdollista kehittää } \\
\text { loudellisia vahinkoja. Tietotuotteiden } \\
\text { ostaisi hakkuu- ja korjuuoperaatioiden } \\
\text { Inko- ja juuristovaurioita. Selvityksen } \\
\text { tavuus. Vaikka hankkeessa kehitetyistä } \\
\text { ttteluissa tuotiin esiin kuitenkin useita } \\
\text { ta pidettiin mahdollisena. }\end{array}$ \\
\hline \multicolumn{3}{|l|}{ Julkaisijayksikkö } \\
\hline \multicolumn{2}{|c|}{$\begin{array}{l}\text { Luokitus (UDK) } \\
\text { 551.515.9, 551.556.1, 551.577, 551.582, 551.583.16, } \\
624.139 .26,632.11\end{array}$} & \\
\hline \multicolumn{3}{|l|}{$\begin{array}{l}\text { ISSN ja avainnimike } \\
\text { ISSN 0782-6079 Raportteja }\end{array}$} \\
\hline $\begin{array}{l}\text { ISBN } \\
\text { 978-952-336-132-4 (nide) } \\
978-952-336-131-7 \text { (pdf) }\end{array}$ & ruotsIKsI ja engIannIKsI) & Sivu \\
\hline
\end{tabular}


Utgivare

Meteorologiska institutet

Erik Palméns plats 1, PB 503

00101 Helsingfors

Författare: Ari Venäläinen, Sanna Luhtala, Mikko Laapas, Otto Hyvärinen, Hilppa Gregow, Mikko Strahlendorff, Mikko Peltoniemi, Susanne Suvanto, Seppo Nevalainen, Heli Peltola, Leena A. Leskinen, Hannu Ala-Honkola, Yrjö Niskanen, Asko Poikela, Marjo Maidell, Paula Horne, Olli-Pekka Ruuskanen

Rubrik: Väder- och klimatinformation samt nya tjänster hjälper skogesbioekonomin att anpassa sig till klimatförändringen

Klimatförändringen orsakade risker för skogar ökar, och därför behövs effektiva anpassningsåtgärder. I Säätyö-projektet finansierat av jord- och skogsbruksministeriet har vi sammanfattat data som underlättar anpassning, utvecklat väder- och klimattjänster som gynnar skogsbruket och kartlagt vilken typ av nya väderoch klimattjänster som behövs inom skogsbruket. Dessutom har vi registrerat viktiga ytterligare utvecklingsbehov för att främja anpassning.

Säätyö-projektet utvecklade en tjänsteprodukt som beskriver trädens skördeförhållanden baserat på markfuktighetsbedömningen. Resultatet inkluderar en analys av den aktuella situationen och en 10dagarsprognos. Projektet testade också nyttan av långa prognoser utöver tre månader. Väderprognostjänsten läggs på sidan och kompletteras av ytterligare ett samarbetsprojekt mellan Finska meteorologiska institutet och Metsäteho som heter HarvesterSeasons (https://harvesterseasons.com/). HarvesterSeasons-tjänsten använder långsiktiga prognoser på upp till 6 månader för att förutse terrängförhållandena.

En testversion av verktyget för risk för vindskador utvecklades i samarbete med Finlands meteorologiska institut vid Institutionen för skogsvetenskaper vid Östra Finlands universitet. Den kan användas för att beräkna de vindhastigheter som krävs i ett skogsområde för vindskador (fallande träd). Det är för närvarande endast lämpligt för forskaranvändning. Säätyö-projektet testade också möjligheten att lokalisera de hårdaste vindskadorna omedelbart efter en storm. Metoden är baserad på rumslig interpolering av vindobservationer. Metoden användes för att analysera stormar som orsakade skogsskador sommaren och hösten 2020. Den producerade kartan ansågs illustrativ och användbar.

Ackumulering av snöbrott kan modelleras med hjälp av väderdata som regn, temperatur, luftfuktighet och vindhastighet. I Säätyö-projektet utvecklades modellen för riskbedömning av snöskador på ett sådant sätt att, förutom den ackumulerade snöbrotten också hänsyn togs till stativets egenskaper och variationer i terränghöjd. Enligt verifieringen ökade vikten av abiotiska faktorer under extrema snöbelastningsförhållanden (vintern 2017-2018). Under vanliga vintrar betonades vikten av biotiska faktorer. Enligt jämförelsen kunde de faktiska snöskadorna förklaras väl med den testade modellen.

I intervjuerna och workshopen kartlade projektet användningen av informationsprodukter, deras fördelar, villkoren för deras introduktion och utvecklingsmöjligheter. Enligt resultaten sågs olika användningsområden och fördelar med informationsprodukter och tjänster. Informationsprodukter skulle göra det möjligt att utveckla proaktiv skogsförvaltning, vilket skulle minska den ekonomiska skada som orsakats av förstörelse. En mer uppdaterad förståelse för skördeförhållanden, möjliggjort av informationsprodukter, skulle förbättra genomförandet av skörde- och skördeoperationer och hanteringen av virkesbestånden samt minska terrängoch stam- och rotskador. Enligt studien påverkas införandet av information särskilt av tillgängligheten. Även om de för närvarande inte var villiga att betala för de informationsprodukter som utvecklades i projektet, belyste intervjuerna flera förslag för utveckling av informationsprodukter, vilket gjorde det möjligt att kommersialisera dem.

Publikationsenhet

Forskning av väder och klimatförändringens effekter

Klassificering (UDK)

551.515.9, 551.556.1, 551.577, 551.582, 551.583.16,

624.139.26, 632.11

Nyckelord

klimat, anpassning till

klimatförändringen, skogsförvaltning

ISSN ja och serietitel

ISSN 0782-6079 Rapporter

\begin{tabular}{l|l|l}
\hline ISBN & Språk & Sidantal \\
$\begin{array}{l}\text { 978-952-336-132-4 (volum) } \\
\text { 978-952-336-131-7 (pdf) }\end{array}$ & $\begin{array}{l}\text { finska (sammandrag också } \\
\text { på svenska och engelska) }\end{array}$ & 52 \\
\hline
\end{tabular}

978-952-336-131-7 (pdf) på svenska och engelska) 


\begin{tabular}{|c|c|c|}
\hline \multirow{2}{*}{\multicolumn{2}{|c|}{$\begin{array}{l}\text { Publisher } \\
\text { Finnish Meteorological Institute } \\
\text { Erik Palménin aukio } 1 \\
\text { P.O. Box } 503 \\
00101 \text { Helsinki, Finland }\end{array}$}} & \\
\hline & & \\
\hline \multicolumn{2}{|c|}{$\begin{array}{l}\text { Authors: Ari Venäläinen, Sanna Luhtala, Mikko Laapas, } \\
\text { Otto Hyvärinen, Hilppa Gregow, Mikko Strahlendorff, Mikko } \\
\text { Peltoniemi, Susanne Suvanto, Seppo Nevalainen, Heli } \\
\text { Peltola, Leena A. Leskinen, Hannu Ala-Honkola, Yrjö } \\
\text { Niskanen, Asko Poikela, Marjo Maidell, Paula Horne, Olli- } \\
\text { Pekka Ruuskanen }\end{array}$} & $\begin{array}{l}\text { by } \\
\text { riculture and }\end{array}$ \\
\hline \multicolumn{3}{|c|}{$\begin{array}{l}\text { Title: Weather and climate information and new services will } \\
\text { to climate change }\end{array}$} \\
\hline $\begin{array}{l}\text { Climate change will increase } \\
\text { In Säätyö project funded by th } \\
\text { adaptation measures, develope } \\
\text { weather and climate services ar } \\
\text { to promote adaptation. } \\
\text { The Säätyö project develope } \\
\text { moisture assessment. The outp } \\
\text { we also tested the usefulness o } \\
\text { and supplemented by another } \\
\text { called HarvesterSeasons (https: } \\
\text { of up to } 6 \text { months to assess terr } \\
\text { A test version of a wind dam } \\
\text { of the University of Eastern Fi } \\
\text { speeds required in a forest area } \\
\text { the Säätyö project the possibil } \\
\text { also tested. The method is base } \\
\text { storms that caused forest dama } \\
\text { and useful to those responsible } \\
\text { The accumulation of snow on } \\
\text { humidity, and wind speed. In th } \\
\text { such a way that, in addition to t } \\
\text { in terrain height were also take } \\
\text { factors increased under extrem } \\
\text { biotic factors was emphasized. } \\
\text { the tested model. } \\
\text { In the interviews and work } \\
\text { introduction and development } \\
\text { information products and servi } \\
\text { forest management, which wo } \\
\text { date understanding of harvestir } \\
\text { of harvesting and harvesting or } \\
\text { root damage. According to the } \\
\text { timeliness. Although the interv } \\
\text { the project, the interviews hig } \\
\text { could make it possible to comn }\end{array}$ & $\begin{array}{l}\text { her induced risks to forests, } \\
\text { istry of Agriculture and For } \\
\text { ather and climate services th } \\
\text { eded in forestry. In addition, } \\
\text { ervice product describing th } \\
\text { cludes an analysis of the cur } \\
\text { g forecasts beyond three mo } \\
\text { peration project between the } \\
\text { vesterseasons.com/). The Ha } \\
\text { earing conditions. } \\
\text { isk tool was developed in co } \\
\text { and the Finnish Meteorolog } \\
\text { wind damage (falling trees). } \\
\text { f locating the most severe w } \\
\text { the spatial interpolation of w } \\
\text { the summer and fall of } 202 \\
\text { ompiling the situational pict } \\
\text { branches, can be modeled us } \\
\text { ätyö project, the snow damag } \\
\text { cumulated snow load amoun } \\
\text { o account. According to the } \\
\text { w load conditions (winter } 2 \\
\text { rding to the comparison, the }\end{array}$ & 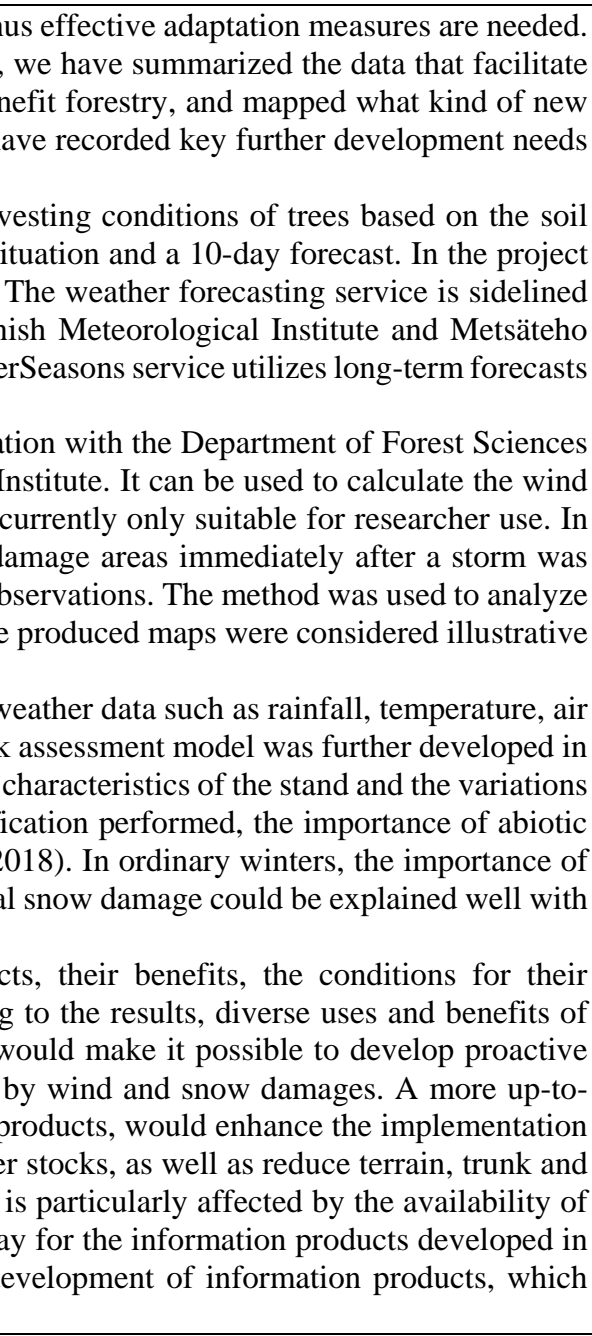 \\
\hline \multicolumn{3}{|l|}{ Publishing unit } \\
\hline \multicolumn{2}{|c|}{$\begin{array}{l}\text { Classification (UDK) } \\
\text { 551.515.9, 551.556.1, 551.577, 551.582, 551.583.16, } \\
624.139 .26,632.11\end{array}$} & cha \\
\hline \multicolumn{3}{|l|}{$\begin{array}{l}\text { ISSN and series title } \\
\text { ISSN 0782-6079 Reports }\end{array}$} \\
\hline $\begin{array}{l}\text { ISBN } \\
\text { 978-952-336-132-4 (print) } \\
978-952-336-131-7 \text { (pdf) }\end{array}$ & & 52 \\
\hline
\end{tabular}




\section{ESIPUHE}

Ilmastonmuutoksen arvioidaan lisäävän metsiin kohdistuvia riskejä. Riskit ovat luonteeltaan moninaisia, ja siksi myös keinot riskien hallintaan vaihtelevat tapauskohtaisesti. On myös kehitettävä uusia työvälineitä siihen, miten voimme tuottaa ajantasaista tietoa riskeistä ja miten voimme tehokkaasti saattaa tietoa metsäalan toimijoiden ja metsänomistajien käyttöön. Metsäbiotalous tarvitsee ilmastonmuutokseen sopeutumisen tueksi tehokkaita tietoaineistoja ja ilmastopalveluita.

Suomessa metsillä on suuri taloudellinen, sosiaalinen ja ekologinen merkitys. Metsillä on tärkeä tehtävä, kun pyritään hillitsemään ilmastonmuutosta, sillä ne sitovat hiiltä ilmakehästä ja varastoivat sitä terveeseen ja kasvavaan puustoon sekä maaperään. Kun kansallista metsästrategiaa laadittiin, uudeksi painopistealueeksi valittiin ilmastokestävä metsätalous. Se pitää sisällään metsien hiilensidonnan vahvistamisen ilmastonmuutoksen hillitsemiseksi sekä sopeutumisen ilmastonmuutokseen. Nämä tavoitteet tukevat toisiaan ja kytkeytyvät vahvasti toisiinsa.

Sopeutuminen muuttuviin sääolosuhteisiin, kuten myrskyjen aiheuttamiin tuhoihin, on metsätalouden avainkysymyksiä. Myrskyt aiheuttavat vahinkoja erityisesti talvella silloin, jos maa on roudaton. Talvien lämpeneminen ja routakauden lyhentyminen lisäävät paitsi tuulituhojen myös puuston korjuun aiheuttamien vaurioiden riskiä. Viime vuosina lumituhoja on esiintynyt alueilla, joissa niitä ei aiemmin ole laajassa mitassa tavattu.

Metsätalouden toimilla voidaan edistää metsien sopeutumista ilmastonmuutokseen. Riskeihin varautuminen edellyttää, että metsänomistajilla ja toimijoilla on käytettävissään ajantasaista tietoa metsiä koskevista riskeistä. Lisäksi viranomaiset tarvitsevat tietoa ajantasaisen tilannekuvan laadintaan. Säätyö-hankkeessa on pyritty löytämään ratkaisuja näihin tarpeisiin.

Säätyö-hanke toteutettiin vuosina 2018-2020, ja hankkeen rahoitti maa- ja metsätalousministeriö "Kansallista metsästrategiaa, kansallista ilmastonmuutokseen sopeutumissuunnitelmaa ja biotalousstrategiaa" tukevien hankkeiden rahoituksesta. Hankkeen tulokset tukevat riskienhallintaa, edistävät analysoidun tiedon saatavuutta, uusien työkalujen käyttöönottoa sekä luovat pohjaa kehitystyön jatkamiselle, kaupalliset mahdollisuudet mukaan lukien. 


\section{SISÄLLYSLUETTELO}

Esipuhe

Yhteenveto päättäjille

1. Metsäbiotalous tarvitsee tietoa ja palveluita sää- ja ilmastoriskien pienentämiseksi 12

2. Säätyö-hankkeen tavoitteena oli tuottaa tarkempia sää- ja ilmastoaineistoja

sekä uusia ennustetuotteita metsäbiotalouden tarpeisiin

3. Avoimia metsä-, sää- ja ilmastoaineistoja on saatavissa runsaasti

3.1 Ilmatieteen laitos tuottaa ja tarjoaa sekä säähavaintoasemakohtaista että hilamuotoista tietoa

3.1.1 Lähes kaikki säähavaintoasemakohtaiset aineistot ovat avoimia

3.1.2 Ilmatieteen laitoksen hila-aineistot löytyvät Paituli-palvelusta

3.1.3 Harvesterseasons.com palvelu visualisoi korjuukelpoisuustietoja ja -ennusteita

3.2 Suomen metsäkeskus ja Luonnonvarakeskus tarjoavat avointa metsätietoa

3.2.1 Suomen metsäkeskus tarjoaa tietoa yksityismetsistä

3.2.2 Luonnonvarakeskus tarjoaa avoimesti valtakunnan metsien inventointiin perustuvaa avointa tietoa

3.3 Maanmittauslaitos tarjoaa avoimesti karttoja, ilmakuvia, kiinteistörajatietoja ja laserkeilausaineistoja

3.4 Suomen ympäristökeskuksen avoimet aineistot sisältävät mm.

kosteusindeksitiedot

3.5 Copernicus-ohjelma tarjoaa Euroopan ja maapallon kattavia avoimia aineistoja

3.6 Vaikutustietokannat kokoavat yhteen sääilmiöiden aiheuttamat yhteiskunnalliset vaikutukset

4. Säätyöhanke kehitti uusia metsäbiotaloutta tukevia palveluita

4.1 Puiden lumituhoriskin kartoituksessa otetaan huomioon säätekijöiden lisäksi metsän ominaisuudet ja maaston korkeusvaihtelut

4.2 Maaston kantavuuden arviointia ja ennusteita varten kehitetiin uusi palvelu

4.2.1 Maaston kantavuus ja puuston korjuukelpoisuus

4.2.2 Uusi korjuukelpoisuuspalvelu tuottaa tilanne- ja ennustetietoa kivennäismaan pintakerroksen kosteudesta

4.3 Hankkeessa kartoitettiin puuston tuulituhoriskiä

4.3.1 Tuulituhoriskityökalusta kehitetiin testiversio

4.3.2 Hankkeessa testattiin myrskyn jälkeisten mahdollisten tuulituhoalueiden kartoittamista

5. Metsäbiotalouden toimijat tarvitsevat helposti arjessa käytettäviä tietotuotteita

5.1 Tietotuotteiden tulee tarjota käyttäjille ratkaisuja päätöksentekoon työpajatyöskentelyä

5.3 Haastattelujen ja työpajan tulosten mukaan tietotuotteet ja -palvelut ovat hyödyllisiä ja tarpeellisia 
5.3.1 Haastateltavien mielestä uusia tietotuotteita voi käyttää monipuolisesti

5.3.2 Palvelumuotoilu-työpaja vahvisti haastatteluiden tulokset

5.4 Tietotuotteiden peruskäyttö voisi olla toivotusti ilmaista mutta

lisäominaisuudet maksullisia

6. Suosituksia jatkotoimenpiteille

Kiitokset

50

Kirjallisuusluettelo 


\section{Yhteenveto päättäjille}

Kun ilmastonmuutos etenee, sen vaikutukset kasvavat. Osittain muutoksen vaikutukset Suomen metsissä ovat hyödyllisiä, mutta myös metsiin kohdistuvat bioottiset ja abioottiset riskit tulevat kasvamaan. Esimerkiksi roudan väheneminen lisää puiden tuulituhoriskiä ja myös vaikeuttaa puiden korjuuta heikosti kantavilta maastotyypeiltä. Arvioiden mukaan metsien lumituhoriski kasvaa Suomen pohjoisosissa ja pienenee maan eteläosissa. Suomen metsien säilyttäminen elinvoimaisena ekosysteemipalveluiden tarjoajana edellyttää tehokkaita sopeutumistoimia. Tässä Säätyö-hankkeessa olemme tehneet yhteenvedon sopeutumista auttavista tietoaineistoista, kehittäneet metsätaloutta hyödyttäviä sää- ja ilmastopalveluita sekä kartoittaneet metsätalouden sää- ja ilmastopalveluiden tarvetta. Lisäksi olemme kirjanneet keskeisiä sopeutumista edistäviä jatkokehitystoimia.

Ilmastonmuutoksen vaikutusten ja sopeutumistoimien tueksi on tarjolla runsaasti aineistoja, jotka kuvaavat mennyttä ilmastoa (taulukko 3.1) ja myös ilmastonmuutosta tulevien vuosikymmenten aikana. Aineistot ovat pääosin avoimesti saatavilla. Aineistot sisältävät sääasemakohtaisia tietoja mutta myös hilaruudukkoon alueellistettuja havaintotietoja. Euroopan ja maailman kattavia sää- ja ilmastoaineistoja tarjoaa Euroopan unionin Copernicuspalvelu.

Säätyö-hankkeessa kehitettiin puunkorjuun suunnittelun tueksi maan pintakerroksen kosteutta kuvaava palvelutuote. Palvelussa esitetään säätietojen avulla laskettu kosteusanalyysi vallitsevasta tilanteesta sekä 10 vuorokauden ennuste. Hankkeessa myös testattiin pitkien, kolmen kuukauden päähän ulottuvien ennusteiden mahdollisuutta. Säätyö-hankkeessa kehitettyä ennustepalvelua sivuaa, hyödyntää ja täydentää toinen Ilmatieteen laitoksen ja Metsätehon yhteistyöhanke nimeltään HarvesterSeasons (https://harvesterseasons.com/). HarvesterSeasons-palvelu hyödyntää Säätyö-hankkeen kosteustiedon ohella pitkiä, reilun kuuden kuukauden päähän ulottuvia ennusteita maaston kantavuusolosuhteiden arvioinnissa.

Kantavuusennusteen osuvuutta tutkitaan mm. HarvesterSeasons-hankkeessa vertaamalla sitä kesäkaudella 2020 korjattujen leimikoiden toteumatietoihin (tarkka sijainti, korjuuajankohta, sanallinen arvio kantavuusolosuhteista). Vertailun tulosten pohjalta arvioidaan, soveltuuko Säätyö-hankkeessa tuotettu kosteustieto operatiiviseen käyttöön. Lisäksi selvitetään mitkä kosteustasot indikoivat parhaiten sitä, että korjuukelpoisuudeltaan ns. kuivan tai normaalin kesän kohteiksi luokitellut kuviot kantavat korjuukoneet.

Tuulituhoja voitaisiin ennaltaehkäistä, jos metsien hakkuut suunniteltaisiin siten, että puiden kaatumisriski jäisi mahdollisimman pieneksi. Säätyö-hankkeessa kehitetyllä tuulituhoriskityökalun testiversiolla voidaan laskea puuston tuulituhoon (puiden kaatuminen) tarvittavia tuulennopeuksia metsäalueilla. Riskiin vaikuttaa puulajin lisäksi puuston koko ja sijainti suhteessa tuulelle alttiiseen metsän reunaan. Tuulituhon syntyyn tarvittavia tuulennopeuksia eri ilmansuunnista voidaan tarkastella mikrokuvioilla (16 m × $16 \mathrm{~m})$ ennen ja jälkeen uuden avohakkuualan tai -alojen teon. Työkalulla voidaan myös havainnollistaa näiden tuulennopeuksien todennäköisyyksiä eri ilmansuunnista ja arvioida puuston tuulituhoriskiä eri myrskytapausten tuulennopeuksilla. Työkalu on kehitetty Itä-Suomen yliopiston Metsätieteiden osastolla yhteistyössä Ilmatieteen laitoksen kanssa. Se soveltuu tällä hetkellä vain tutkijakäyttöön.

On tärkeää, että laajoja metsätuhoja aiheuttavan myrskyn jälkeen saadaan nopeasti mahdollisimman luotettava tilannekuva siitä, mille alueille myrskytuhoja on tullut. Tällaisen analyysin pohjalta jatkotoimenpiteet voidaan kohdistaa ja mitoittaa mahdollisimman tehokkaasti. Säätyö-hankkeessa testattiin mahdollisuutta paikantaa pahimmat tuulituhoalueet 
välittömästi tapahtuneen myrskyn jälkeen. Menetelmänä käytettiin sääasemilla tehtävien tuulihavaintojen alueellista interpolointia. Menetelmää testattiin kesällä ja syksyllä 2020 metsätuhoja aiheuttaneiden myrskyjen Päivö (30.6.2020), Aila (17.9.2020) sekä Liisa (19.11.2020) jälkeen. Tehtyjä kartta-analyysejä pidettiin havainnollisina ja hyödyllisinä tilannekuvan laadinnan apuvälineinä.

Lumen kertymää puiden oksille voidaan mallintaa säätietojen, kuten sademäärä, lämpötila, ilman kosteus ja tuulen nopeus, avulla. Tällainen lumikuorma-analyysi ja -ennuste on saatavilla Ilmatieteen laitokselta kaupallisena palveluna. Säätyö-hankkeessa lumituhoriskin arviointimallia kehitetiin edelleen siten, että kertyneen lumikuorman lisäksi selittäjäksi otetiin myös puuston ominaisuudet sekä maaston korkeusvaihtelut. Mallin antamia arvioita lumituhoista verrattiin toteutuneisiin lumituhoihin. Abioottisten tekijöiden merkitys kasvoi äärimmäisissä lumikuormaolosuhteissa (talvi 2017-2018). Tavallisina talvina puolestaan korostui bioottisten tekijöiden merkitys. Vertailun mukaan toteutuneet lumituhot pystyttiin selittämään testatulla mallilla hyvin. Epävarmuutta vertailuun tuo se, että vertailussa käytetyistä metsänkäyttöilmoituksista ei ilmene tuhon voimakkuus. Myöskään ei tiedetä, kuinka kattavasti lumituhokoodia on käytetty niissä hakkuuilmoituksissa, joissa hakkuun liikkeelle sysäävänä tekijänä on ollut lumituho. Lisäksi osa metsänomistajista saattaa kerätä lumituhopuut kotitarvepuuksi, jolloin metsänkäyttöilmoitusta ei tarvitse jättää. Mallin avulla lumituhoarviot lasketaan joko lohkoittain tai hilaruudukkoon, jonka koko on $16 \mathrm{~m} \times 16 \mathrm{~m}$. Mallin avulla tuotettua lumituhoriskiarviota testataan talvella 2020-2021. Lumituhoriski julkaistaan avoimena palveluna Suomen metsäkeskuksen verkkosivustolla. Karttapalvelun jatkosta tehdään päätös vuonna 2021.

Säätyö-hankkeessa kartoitettiin haastatteluissa ja työpajassa säähän ja ilmastonmuutokseen liittyvien tietotuotteiden käyttökohteita, hyötyjä, käyttöönoton edellytyksiä ja kehitysmahdollisuuksia. Tulosten mukaan tietotuotteille ja -palveluille nähtiin monipuolisia käyttömahdollisuuksia ja käytön myötä saatavia hyötyjä. Tietotuotteiden avulla olisi mahdollista kehittää ennakoivaa metsänhoitoa, joka pienentäisi tuhoista aiheutuvia taloudellisia vahinkoja. Tietotuotteiden mahdollistama entistä ajantasaisempi käsitys korjuuolosuhteista tehostaisi hakkuu- ja korjuuoperaatioiden toteutusta ja puuvarastojen hallintaa sekä vähentäisi niin maasto kuin runko- ja juuristovaurioita. Selvityksen mukaan tiedon käyttöönottoon vaikuttavat etenkin sen 1) ajantasaisuus (tiedon tulisi huomioida vallitsevat olosuhteet), 2) saatavuus (tiedon tulisi olla saatavilla helposti ja käytössä olevasta järjestelmästä) ja 3) maksuttomuus (hankkeessa kehitetyistä tietotuotteista ei oltu tällä hetkellä valmiita maksamaan). Haastatteluissa tuotiin esiin kuitenkin useita tietotuotteiden kehitysehdotuksia, joiden myötä niiden kaupallistamista pidettiin mahdollisena.

Tietotuotteiden käyttöä koskevissa keskusteluissa korostui tarve tuottaa, koota yhteen ja viestiä valtakunnallista tietoa niistä metsiin kohdistuvista riskeistä, joita ilmastonmuutos tuo. Etenkin nähtiin tarpeelliseksi tuottaa arvioita niistä taloudellisista vahingoista, joita riskit voivat toteutuessaan aiheuttaa. Tämä havainnollistaisi tiedon kehittämisestä ja käytöstä saatavia hyötyjä, ohjaisi kehittämisresursseja sekä kannustaisi uusien tietotuotteiden käyttöön.

Ilmastonmuutos etenee hillintätoimista huolimatta ja metsäbiotalous tarvitsee sopeutumisen tueksi tehokkaita tietoaineistoja ja ilmastopalveluita. Taulukkoon 1 on koottu ilmastonmuutoksen keskeisiä metsiin ja metsätalouteen kohdistuvia vaikutuksia sekä sää- ja ilmastoaineistoja ja tuotteita, jotka auttavat sopeutumistoimia. Osa taulukkoon kootuista aineistoista ja palveluista on jo toiminnassa olevia, osa pilotointivaiheessa ja osa vaatii vielä kehittämistä.

Osaa Säätyö-hankkeessa kehitetyistä palveluista voidaan jo soveltaa käytännössä, vaikka ne eivät vielä olekaan välttämättä aivan lopullisessa muodossaan. 
Taulukko 1. Ilmastonmuutoksen vaikutuksia Suomen metsiin ja metsätaloudelle sekä muutokseen sopeutumista auttavia sää- ja ilmastoaineistoja ja palveluita.

\begin{tabular}{|ll|}
\hline Muutos & Vaikutus \\
\hline $\begin{array}{l}\text { Talvet lauhtuvat ja } \\
\text { routa vähenee }\end{array}$ & Tuulituhoriski kasvaa \\
& $\begin{array}{l}\text { Maaston ja metsäautoteiden kantavuus } \\
\text { huononee ja puiden korjuu vaikeutuu } \\
\text { ja samalla juuristovaurioiden ja } \\
\text { esimerkiksi juurikäävän aiheuttamien } \\
\text { tuhojen riski kasvaa }\end{array}$ \\
& $\begin{array}{l}\text { Lumituhoriski kasvaa erityisesti } \\
\text { Pohjois-Suomessa ja Itä-Suomen } \\
\text { valvet lauhtuvat ja } \\
\text { muuttuvat } \\
\text { kosteammiksi }\end{array}$
\end{tabular}

Talvet lauhtuvat ja kovat pakkaset tulevat harvinaisemmiksi

Kesäaikainen kuivuus lisääntyy

Kasvukauden

lämpösumma kasvaa

Joidenkin tuhohyönteisten kuten lehtija havununnan talvehtimisolot paranevat ja niiden esiintymisriski kasvaa

Kuusimetsien kasvu voi vähentyä vettä heikosti pidättävillä mailla etenkin Etelä-Suomessa

Puiden korjuu mahdollista huonosti kantavilta alueilta nykyistä useammin

Tuhohyönteiset, kuten kirjanpainaja yleistyvät

\section{Sopeutumista auttava työkalu/aineisto}

Tuulituhoriskityökalun käyttö hakkuita suunniteltaessa. ${ }^{[1]}$ Myrskytilanteen jälkeinen tuulikenttäanalyysi ${ }^{[1]}$

Maaston kulkukelpoisuus analyysit ja ennusteet (10 vrk-3 kk). ${ }^{[2]}$

Ilmastonmuutoksen skenaarioihin pohjautuva arvio lumituhoriskin muutoksesta. Tämä auttaa valittaessa metsänuudistuksessa käytettävää puulajia tai suunniteltaessa harvennuksen toteutusta. ${ }^{[4]}$

Metsän ominaisuudet huomioiva lumituhoriskin seurantamenetelmä lumituhoalueiden kartoittamiseksi. ${ }^{1]}$

Ilmastonmuutoksen skenaarioihin pohjautuva arvio talvilämpötilojen muutoksesta. ${ }^{[4]}$

Edistynyt havainto- ja mallinnusjärjestelmä, joka huomioi säätietojen ohella maaston ominaisuudet ja tuottaa alueellisesti ja ajallisesti tarkkaa tietoa metsäpalojen syttymisriskistä ja palojen leviämisestä. ${ }^{[3]}$
Ilmastonmuutoksen skenaarioihin pohjautuva arvio kuivuusriskin muutoksesta. Tämä auttaa valittaessa metsänuudistuksessa käytettävää puulajia. ${ }^{[4]}$

Maaston kulkukelpoisuus analyysit ja ennusteet (10 vrk-3 kk). ${ }^{[2]}$

Ilmastonmuutoksen skenaarioihin pohjautuva arvio kasvukauden lämpösumman muutoksesta. Tämä auttaa valittaessa metsänuudistuksessa käytettävää puulajia sekä suunniteltaessa muita toimenpiteitä, jotka alentavat hyönteistuhoriskiä. ${ }^{[4]}$

Alueellisesti tarkat mikroilmaston vaihtelut huomioivat lämpösumman kehittymistä seuraavat analyysit ja ennusteet (10 vrk-3 kk). ${ }^{[3]}$

Vesiensuojelun kartta-aineistot, kuten vesien virtausmallit ja Rusle-eroosiomallinnus.

\section{Sademäärät kasvavat}

Talviset sateet tulevat vetenä, kesäiset rankkasateet voimistuvat. Nämä lisäävät ravinteiden huuhtoutumista

[1] Tuote on kehitetty pilottivaiheeseen Säätyö-hankkeessa, mutta tuotteistaminen on kuitenkin kesken. Pitkän ajan keskiarvoista lumituhoriskiä ennustava karttatuote julkaistaan hankkeen päättyessä Luken sivuilla.

${ }^{[2]}$ Palvelua on kehitetty ja testattu operationaalisena palveluna Säätyö-hankkeessa 3 kk ja harvesterseasons.com-palvelussa 6 kk tulevaisuuteen.

[3] Palvelua kehitetään muissa meneillään olevissa hankkeissa.

${ }^{[4]}$ Aineistot ovat olemassa ja avoimesti saatavilla. 


\section{Metsäbiotalous tarvitsee tietoa ja palveluita sää- ja ilmastoriskien pienentämiseksi}

- Ilmastonmuutos vaikuttaa metsien kasvuun ja puuntuotantoon sekä puunkorjuuolosuhteisiin.

- Ilmastonmuutos lisää erilaisia sää- ja ilmastoriskejä, mitkä pitää ottaa huomioon metsien hoidossa ja hakkuissa.

- Lisääntyviin sää- ja ilmastoriskeihin varautuminen ja niiden hallinta edellyttää ajallisesti ja alueellisesti tarkkaa tietoa menneestä, nykyisestä ja tulevasta säästä ja ilmastosta.

Metsäbiotaloudella on tärkeä merkitys sekä ilmastonmuutoksen hillinnälle että Suomen kansantaloudelle. Ilmasto määrittää yhdessä kasvupaikkatekijöiden kanssa, kuinka nopeasti metsät kasvavat ja mitkä puulajit täällä menestyvät. Ilmaston vaihtelut ja -muutos sään ääriilmiöineen, kuten myrskyt (kovat tuulet), kuivuus ja runsas lumisade voivat aiheuttaa laajoja metsätuhoja. Ilmasto-olosuhteet vaikuttavat myös puunkorjuuolosuhteisiin. Roudattomuus ja runsaat sateet vaikeuttavat puunkorjuuta alueilla, joilla maan kantavuus on huono. Ilmastonmuutos lisää edellä kuvattuja metsiin kohdistuvia sää- ja ilmastoriskejä (Venäläinen ym., 2020; Lehtonen ym., 2020). Ilmastonmuutos edellyttää metsätaloudelta valmiutta sopeutua tähän muutokseen. Kestävä metsäbiotalous puolestaan edellyttää kattavia sää- ja ilmastotietoja lisääntyvien sää- ja ilmastoriskien hallintaa varten.

Metsäbiotalouden merkitys Suomelle on suuri. Suomessa on noin 23 miljoonaa hehtaaria metsää, josta yksityismetsien pinta-ala on noin 14 miljoonaa hehtaaria. Yksityisiä metsänomistajia on noin 600 000. Metsähallitus ja metsäteollisuus sekä kunnat yms. omistavat noin 9 miljoonaa hehtaaria metsää. Tästä huolimatta esimerkiksi vuonna 2018 Suomessa hakatusta ainespuumäärästä 83 \% tuli yksityismetsistä. Tähän on kaksi syytä. Ensiksi pääosa Metsähallituksen maista on Lapissa, missä puuston kasvu on huomattavasti hitaampaa kuin etelämpänä. Toiseksi Metsähallitus hallinnoi luonnonsuojelualueita, joilla ei tehdä hakkuita. Yksityismetsänomistajat saavat vuosittain hakkuutuloja keskimäärin 120-150 € hehtaaria kohden metsänhoitokulujen jälkeen. Valtion mailla tuotto on pienempi. Yksityismetsänomistajat saavat puun myyntituloja noin 1,5-2 miljardia euroa vuodessa. Työpaikkoja metsätaloudessa on noin 42 000. Jatkojalostuksen jälkeen vuonna 2018 metsäteollisuuden viennin arvo oli 13,2 miljardia euroa, mikä muodosti noin 20,7 \% Suomen kokonaisviennin arvosta (Metsateollisuus.fi/tilastot). Runkopuun vuotuinen hakkuukertymä on kasvanut vuoden 1991 noin 40 miljoonasta kuutiometristä yli 72 miljoonaan kuutiometriin vuonna 2017.

Ilmastonmuutoksen myötä metsiin kohdistuvat sää- ja ilmastoriskit lisääntyvät (Venäläinen ym., 2020). Puunkorjuu vaikeutuu lumen ja roudan vähetessä sekä kosteiden kelien lisääntyessä. Nämä muutokset pitää ottaa huomioon ja niihin tulee mahdollisuuksien mukaan varautua niin, että metsätuhoja saadaan vähennettyä ja metsätalouden, kuten puunkorjuun, yhteydessä syntyvät vauriot seurannaisvaikutuksineen, pidettyä pieninä. Toisaalta, esimerkiksi tuulituhoja ei voida estää kokonaan, käsiteltiin metsää tai ei, mutta niitä voi olla mahdollista vähentää paremmalla riskien hallinnalla.

Metsäbiotaloudella tarkoitetaan metsätalouden lisäksi myös nopeasti kasvavaa luonnontuotealaa: riistataloutta ja luontomatkailua. Esimerkiksi luonnontuotealan oikaisemattomaksi kokonaisliikevaihdon määräksi vuonna 2017 on arvioitu noin 530 miljoonaa euroa (Honkanen, 2019). Ilmastonmuutoksen vuoksi muuttuvat sää- ja 
kasvillisuusolosuhteet vaikuttavat myös luonnontuotealaan. Luonnontuotealan ja riistatalouden näkökulmasta ilmastonmuutoksen vaikutukset metsiin lienevät kuitenkin erilaisia kuin metsätaloudelle, ja niiden selvittäminen vaatisi oman tutkimuksensa ja erilaisen lähestymistavan.

Metsäbiotalouden tarvitsemat säähän ja ilmastoon liittyvät aineistot koostuvat perinteisistä säähavainnoista ja niistä johdetuista tilastollisista suureista, kuten keskiarvoista, hajonnoista ja ääritilanteiden toistuvuusajoista. Tämän lisäksi tarvitaan tietoja soveltavien mallien avulla laskettavista suureista, kuten maan kantavuudesta (roudasta ja lumipeitteen paksuudesta) tai vaikkapa puiden oksille kertyvästä lumen määrästä. Myös kuivuuden ja metsäpalovaaran laskentaan tarvitaan soveltavia malleja. Paitsi havaintoja menneestä ja nykyisestä tilanteesta, tarvitaan ennusteita myös tulevaisuuteen eri pituisille jaksoille. Myös pitkistä kuukausien mittaisista ennusteista voi olla hyötyä.

\section{Säätyö-hankkeen tavoitteena oli tuottaa tarkempia sää- ja ilmasto- aineistoja sekä uusia ennustetuotteita metsäbiotalouden tarpeisiin}

- Säätyö-hankkeessa kartoitettiin metsien lumituhoriskiä ja kehitettiin metsien lumi- ja tuulituhoriskien arviointimenetelmiä

- Hankkeessa rakennettiin puiden korjuuolosuhteiden ennustepalvelu ja kehitettiin säävaikutustietokantaa.

- Hankkeessa testattiin uusien tietotuotteiden käytettävyyttä ja kartoitettiin niiden sovellusmahdollisuuksia eri sidosryhmillä.

Säätyö-hankkeen tavoitteena oli tuottaa uusia ja aiempaa yksityiskohtaisempia sää- ja ilmastoaineistoja ja kehittää uusia ennustetuotteita. Tavoitteena oli myös edistää erilaisten sääja ilmastoaineistojen ja ennusteiden käyttöä metsäbiotalouden toimijoiden keskuudessa.

Hankkeen keskeisiä osatehtäviä olivat:

- Kartoitetaan metsiköiden lumituhoriskit. Riskimalli viedään käytäntöön ja metsänomistajien tietoisuuteen avoimen verkkopalvelun kautta.

- Kehitetään puiden korjuuolosuhteiden ennustepalvelua keskittyen sulan maan olosuhteisiin.

- Kehitetään puuston tuulituhoriskin arviointimenetelmää.

- Kehitetään sää- ja ilmastovaikutustietokantaa kattamaan metsäsektorin fyysiset ja taloudelliset vahingot.

- Kartoitetaan ilmastonmuutoksen vaikutuksia metsäbiotalouden arvoketjun toimintaan ja päätöksentekoon.

- Testataan kehitettyjen tietoaineistojen sekä ennusteiden käyttöä Metsäkeskuksen, Metsätehon sekä Maa- ja metsätaloustuottajien Keskusliiton sidosryhmillä.

- Kartoitetaan yhdessä loppukäyttäjien kanssa kehitettyjen ilmastonmuutokseen sopeutumistyövälineiden ja aineistojen taloudellista vaikuttavuutta sekä kaupallisia ja muita sovellutusmahdollisuuksia.

Hankkeen toteutuksesta vastasi Ilmatieteen laitoksen johtama konsortio, johon kuuluivat ItäSuomen yliopisto, Suomen Metsäkeskus, Metsäteho, Pellervon taloustutkimus, Maa- ja metsätaloustuottajain Keskusliitto (MTK) sekä Luonnonvarakeskus.

Tähän raporttiin on koottu Säätyö-hankkeen keskeisiä tuloksia. Raportissa on esitelty lyhyesti hankkeen yhteydessä kehitetyt uudet tuotteet ja palvelut. Lisäksi raportissa on annettu 
arviot siitä, millaisia sää- ja ilmastopalveluita metsäbiotalous tarvitsee ja kuinka palvelut toivotaan toteutettavan. Raporttiin on koottu tiedot avoimia aineistoja tarjoavista palveluista eli siitä, mistä keskeisiä ilmastotietoja voi ladata. Tämän raportin lisäksi hankkeen tuloksia on julkaistu tieteellisissä artikkeleissa kuten Hyvärinen ym. (2020), Gopalakrishnan ym. (2020) ja Suvanto ym., (2020).

\section{Avoimia metsä-, sää- ja ilmastoaineistoja on saatavissa runsaasti}

- Suomea koskevaa sää- ja ilmastotietoa tarjoaa Ilmatieteen laitos.

- Metsien tilaa ja käyttöä koskevaa tietoa tarjoavat Suomen Metsäkeskus, Luonnonvarakeskus, Maanmittauslaitos ja Suomen ympäristökeskus.

- Euroopan ja maapallon laajuista tietoa ilmastosta ja säästä tarjoaa Euroopan Unionin Copernicus-ohjelma.

- Tiedot voimakkaiden sääilmiöiden vaikutuksista kootaan Vaikutustietokantaan

Metsäbiotalouden toimijoille hyödyllisiä sää- ilmastoaineistoja tuottavat sekä suomalaiset tiedontuottajat (taulukko 3.1 ja luvut 3.1 - 3.4) että EU-tason toimijat (luku 3.5).

\subsection{Ilmatieteen laitos tuottaa ja tarjoaa sekä säähavaintoasemakohtaista että hilamuotoista tietoa}

\subsubsection{Lähes kaikki säähavaintoasemakohtaiset aineistot ovat avoimia}

Ilmatieteen laitos tekee säähavaintoja noin 400 havaintoasemalla. Suurin osa asemista on nykyään automaattisia. Osalla asemista havainnot tehdään kerran päivässä myös manuaalisesti. Säähavaintoja tarvitaan moneen tarkoitukseen, esimerkiksi lento- tai tieliikenteen, merenkulun, matkailun, energiantuotannon, kunnossapidon, maa- ja metsätalouden sääpalveluihin sekä sääennusteiden tuottamiseen (https://www.ilmatieteenlaitos.fi/saahavainnot).

Säähavaintoasemilla havainnoidaan yleisesti ilman lämpötilaa, ilman suhteellista kosteutta, ilmanpainetta, tuulen suuntaa ja nopeutta, sademäärää, kokonaispilvisyyttä ja pilvenkorkeutta, vallitsevaa säätä, näkyvyyttä, lumensyvyyttä ja auringon säteilyä (https://ilmatieteenlaitos.fi/saahavainnot). Mitatuista säätiedoista voidaan edelleen laskea erilaisia johdettuja suureita. Maa- ja metsätalouden kannalta keskeistä on esimerkiksi kasvukauden seuranta. Lämpötilahavaintojen avulla voidaan määrittää ns. termisen kasvukauden alku ja loppu, eli ajanjakso, jolloin vuorokauden keskilämpötila pysyy $+5{ }^{\circ} \mathrm{C}: n$ yläpuolella. Lämpötilan avulla lasketaan myös kasvukauden lämpösumman kehitystä (https://ilmatieteenlaitos.fi/terminen-kasvukausi). Kasvukauden seurantaan kuuluu myös sadeja haihduntasummien seuranta. Näiden avulla on mahdollista arvioida esimerkiksi maan kosteutta ja metsäpalovaaraa.

Lähes kaikki Ilmatieteen laitoksen sää- ja ilmastoaineistot ovat ns. avoimia aineistoja ja tietoja tarvitseva voi ladata ne omaan käyttöönsä. Tietoaineistot on avattu koneluettavassa, digitaalisessa muodossa. Myös laitoksessa tuotettujen lähdekoodien avaaminen on aloitettu. Luettelo ladattavista aineistoista löytyy linkistä http://catalog.fmi.fi /geonetwork/srv/fin/catalog.search\#/home. Aineistot sisältävät säähavaintojen ohella myös esimerkiksi sääennustemallien avulla laskettuja ennusteita sekä merihavaintoja. 
Taulukko 3.1. Keskeiset säähän ja ilmastoon sekä metsien käyttöön liittyvät avoimet suomalaiset tietoaineistot.

\begin{tabular}{|c|c|c|c|}
\hline Aineisto & Lataussivu & Lisätiedot & Tiedontuottaja \\
\hline Sääasemakohtaiset säähavainnot & $\begin{array}{l}\text { https://www.ilmatieteenlaito } \\
\text { s.fi/havaintoien-lataus\#!/ }\end{array}$ & Lataus suoraan taulukkoon & Ilmatieteen laitos \\
\hline $\begin{array}{l}\text { Säähavainnot sekä esimerkiksi } \\
\text { sääennustemallien avulla laskettuja } \\
\text { ennusteita }\end{array}$ & $\begin{array}{l}\underline{\text { http://catalog.fmi.fi/geonetw }} \\
\underline{\text { ork/srv/fin/catalog.search\#/h }} \\
\underline{\text { ome }}\end{array}$ & $\begin{array}{l}\text { WFS-standardia tukevien } \\
\text { sovellusten käyttöön }\end{array}$ & Ilmatieteen laitos \\
\hline Hilamuotoiset säähavainnot & https://www.csc.fi/paituli & & $\begin{array}{l}\text { Ilmatieteen laitos } \\
\text { Paituli-palvelussa }\end{array}$ \\
\hline $\begin{array}{l}\text { Metsänomistajille tietoa mm. } \\
\text { metsien kasvupaikoista ja puustosta, } \\
\text { erityisen tärkeistä elinympäristöistä } \\
\text { sekä metsien käytöstä }\end{array}$ & https://www.metsaan.fi/ & $\begin{array}{l}\text { Tietoa karttapalveluina, } \\
\text { paikkatietoaineistoista } \\
\text { muodostettuina } \\
\text { tiedostopaketteina ja } \\
\text { rajapintoina. }\end{array}$ & $\begin{array}{l}\text { Suomen } \\
\text { metsäkeskus }\end{array}$ \\
\hline $\begin{array}{l}\text { Jalostettua metsätietoa eri } \\
\text { aihealueista, } \\
\text { mm. korjuukelpoisuuskartat }\end{array}$ & $\begin{array}{l}\underline{\text { https://www.metsakeskus.fi/ }} \\
\underline{\text { ilastot-ja-kartat }}\end{array}$ & $\begin{array}{l}\text { Karttapalvelu ja rajapinnan } \\
\text { kautta. }\end{array}$ & $\begin{array}{l}\text { Suomen } \\
\text { metsäkeskus }\end{array}$ \\
\hline Metsätalouden vesiensuojelutietoa & $\begin{array}{l}\text { https://www.metsakeskus.fi/ } \\
\text { metsatalouden- } \\
\underline{\text { vesiensuojelu }}\end{array}$ & $\begin{array}{l}\text { Karttapalvelu ja rajapinnan } \\
\text { kautta. }\end{array}$ & $\begin{array}{l}\text { Suomen } \\
\text { metsäkeskus }\end{array}$ \\
\hline $\begin{array}{l}\text { Valtakunnan metsien inventointiin } \\
\text { perustuva tieto }\end{array}$ & $\begin{array}{l}\underline{\text { https://kartta.paikkatietoikk }} \\
\underline{\underline{\text { una.fi/ }}}\end{array}$ & & Luonnonvarakeskus \\
\hline $\begin{array}{l}\text { Mm. Maasto- ja taustakartat, } \\
\text { ortokuvat ja kiinteistörajat }\end{array}$ & $\begin{array}{l}\underline{\text { https://www.maanmittauslai }} \\
\underline{\text { tos.fi/kartat-ja-paikkatieto }}\end{array}$ & $\begin{array}{l}\text { Eri rajapintapalveluiden } \\
\text { kautta }\end{array}$ & Maanmittauslaitos \\
\hline $\begin{array}{l}\text { Avoimien aineistojen } \\
\text { tiedostopalvelu, mm. } \\
\text { laserkeilauksen pistepilvi }\end{array}$ & $\frac{\underline{\text { https://tiedostopalvelu.maan }}}{\underline{\text { mittauslaitos.fi/tp/kartta }}}$ & & Maanmittauslaitos \\
\hline Mm. kosteusindeksi & $\begin{array}{l}\frac{\text { https://www.syke.fi/fi- }}{\text { FI/Avoin_tieto/Avoimet_raj }} \\
\text { apinnat/Satelliittihavaintoje } \\
\text { n raiapinnat }\end{array}$ & WMS-rajapinta & $\begin{array}{l}\text { Suomen } \\
\text { ympäristökeskus }\end{array}$ \\
\hline $\begin{array}{l}\text { Korjuukelpoisuus ja siihen } \\
\text { vaikuttavat tekijät }\end{array}$ & $\underline{\text { https://harvesterseasons.com }}$ & www-palvelu & Ilmatieteen laitos \\
\hline
\end{tabular}

Yksinkertaisempi, joskin rajatumpi vaihtoehto on ladata tiedot suoraan taulukkoon (https://ilmatieteenlaitos.fi/havaintojen-lataus\#!/). Näin ladattavia hetkellisiä säähavaintoja on tällä hetkellä saatavissa aseman mukaan vuodesta 2010 alkaen. Vuorokausi- ja kuukausihavaintoja puolestaan on ladattavissa 1960-luvulta alkaen. Kaikilla havaintoasemilla ei mitata kaikkia suureita. Ohjeita havaintojen tulkintaan löytyy linkistä https://ilmatieteenlaitos.fi/neuvoja-havaintosuureisiin.

\subsubsection{Ilmatieteen laitoksen hila-aineistot löytyvät Paituli-palvelusta}

Vaikka Suomen säähavaintoverkosto on tiheä, suoria mittauksia ei koskaan voida tehdä jokaisessa tarvittavassa paikassa. Tilanteen korjaamiseksi on kehitetty alueellisia interpolointimenetelmiä, joiden avulla asemapisteissä tehdyt havainnot voidaan levittää kuvaamaan tilannetta asemien välisillä alueilla. Interpolointi tehdään hilaruudukkoon, jossa 
kunkin ruudun koko on esimerkiksi $10 \mathrm{~km} \times 10 \mathrm{~km}$ tai $1 \mathrm{~km} \times 1 \mathrm{~km}$. Ilmatieteen laitoksella havaintojen alueellistamisessa käytetään menetelmää, joka tunnetaan nimellä kriging (Aalto ym., 2012; 2016). Menetelmässä interpoloitavan suureen arvo kussakin hilaruudussa lasketaan sitä lähellä olevien havaintoasemien mittausarvojen perusteella. Laskentamenetelmä ottaa huomioon maaston korkeuden sekä rannikon ja vesistöjen vaikutuksen.

\section{Ilmatieteen laitoksen hilamuotoiset aineistot ovat saatavissa CSC - Tieteen tietotekniikan keskuksen ylläpitämästä Paituli-nimisestä paikkatietoaineistojen latauspalvelusta (https://www.csc.fi/paituli). Paituli on ensisijaisesti suunnattu korkeakouluopiskelijoille ja tutkijoille, mutta suuri osa aineistoista on avoimia kaikille aineistoja tarvitseville. Paituli aloitti toimintansa vuonna 2005, ja tällä hetkellä palvelusta on ladattavissa Helsingin yliopiston, Ilmatieteen laitoksen, Karelia-ammattikorkeakoulun, Kotimaisten kielten keskuksen, Maanmittauslaitoksen, Luonnonvarakeskuksen, Maaseutuviraston, Tilastokeskuksen, Väestörekisterikeskuksen sekä Väyläviraston tuottamia paikkatietoaineistoja. Aineistojen kuvaukset eli metadatat ovat saatavilla linkistä https://paituli.csc.fi/metadata.html.}

Ilmatieteen laitoksen aineistot sisältävät hilaruudukkoon interpoloituja tietoja vuodesta 1961 eteenpäin. Aineiston joukossa on myös vuoteen 2100 ulottuvia arvioita tulevasta ilmastostamme. Aineistojen alueellinen tarkkuus on joko $10 \mathrm{~km} \times 10 \mathrm{~km}$ tai $1 \mathrm{~km} \times 1 \mathrm{~km}$. Aineistot sisältävät tietoja lämpötilasta, sademäärästä, tuulen nopeudesta, ilman suhteellisesta kosteudesta ja auringon säteilystä.

Paituliin on ladattu myös aineistokokonaisuus, joka tuotettiin Suomen akatemian strategisen tutkimusneuvoston 2015-2021 rahoittamassa tutkimushankkeessa, "Kestävä, ilmastoneutraali ja resurssitehokas metsäbiotalous” (FORBIO). Se sisältää joukon ilmastomuuttujia, joita voidaan hyödyntää maa- ja metsätalouden tutkimuksessa ja sovellutuksissa. Nämä aineistot sisältävät tietoja puiden lumikuormasta, puunkorjuuolosuhteista ja metsäpalovaarasta sekä voimakkaiden tuulten toistuvuusajoista, jaksolle 1981-2010 (nykyilmasto) säähavaintoihin pohjautuen sekä jaksoille 2021-2050 sekä 2070-2099 ilmastonmuutosarvioihin perustuen. Jälkimmäiset arviot on laskettu kahdelle ilmastonmuutoksen voimakkuusskenaariolle RCP4.5 (maapallon laajuinen keskilämpötilan kohoaminen noin $2{ }^{\circ} \mathrm{C}$ :lla tämän vuosisadan aikana) sekä RCP8.5 (maapallon laajuinen keskilämpötilan kohoaminen noin $4{ }^{\circ} \mathrm{C}$ :lla tämän vuosisadan aikana).

\subsubsection{Harvesterseasons.com palvelu visualisoi korjuukelpoisuusaineistoja ja -ennusteita}

Tiedon käyttäjät ovat toivoneet helppokäyttöistä tietopalvelua, joka sisältää paikallisesti tarkkaa tietoa. Tätä varten Ilmatieteen laitos on kehittänyt rinnakkaisprojektissa modernin Harvesterseasons.com-verkkopalvelun. Sen avulla visualisoidaan sekä Säätyö-hankkeen kehittämiä korjuukelpoisuusaineistoja että rinnakkain kehitettyjä reilun kuuden kuukauden ennusteita. Ennusteet perustuvat EU:n Copernicus-ohjelman vuodenaikaisennusteisiin. Palvelu osaa paikantaa käyttäjän sallimana tietoja kartalle jopa 16 m hilassa korjuukelpoisuusarvion osalta. Lisäksi kartan alta löytää pistemäisiä aikasarjoja kuvaamaan korjuukelpoisuuteen vaikuttavia tekijöitä maaperän kosteus, maaperän lämpötila (routa) ja lumensyvyys. Sarjoissa esitetään vuodenaikaisennusteiden harhaparannettujen parviennusteiden jokaisen jäsenen (51 yhteensä) käyrät. Karttaan käytetään näiden tietoja kun $90 \%$ jäsenistä tukee hyvää tai huonoa keliä korjuukelpoisuuden suhteen. 


\subsection{Suomen metsäkeskus ja Luonnonvarakeskus tarjoavat avointa metsätietoa}

\subsubsection{Suomen metsäkeskus tarjoaa tietoa yksityismetsistä}

Pääosa Suomen metsäkeskuksen tietokannoissa olevista tiedoista tuli avoimiksi aineistoiksi lakimuutoksella 1.3.2018. Ennen lakimuutosta tietojen jakaminen avoimina aineistoina ei ollut mahdollista. Metsäkeskus on usean vuosikymmenen ajan inventoinut yksityismaiden metsiä ja tuottanut metsikkökuvioille puustotietojen lisäksi hakkuu- ja hoitosuosituksia. Tietoja käyttävät metsänomistajat ja metsäammattilaiset suunnitellessaan toimenpiteitä metsissä. Tiedoilla on perinteisesti ollut vahva neuvonnallinen ja toimintaa taloudellisesti kannattavaan metsänhoitoon ohjaava tarkoitus. Samalla ne sisältävät myös luonnon monimuotoisuuteen liittyvät näkökohdat ja muut metsän arvot.

Metsänomistajat ovat voineet tarkastella metsiensä tietoja Metsään.fi-palvelussa vuodesta 2012. Metsätalouden palvelutuottajat ovat voineet tarkastella metsänomistajien tietoja vuodesta 2014. Metsänomistajien tietojen näkyminen toimijalle Metsään.fi-palvelussa edellyttää metsänomistajan suostumuksen. Metsäkeskus on käyttänyt keräämäänsä tietoa myös metsälain valvontaan metsänkäyttöilmoitusten tietojen tarkastuksessa sekä Kemera-tukien myöntämisessä. Hakkuuaikomuksista täytyy metsälain mukaan tehdä metsänkäyttöilmoitus Metsäkeskukseen vähintään kymmenen päivää ennen hakkuun alkua. Metsäkeskus hallinnoi myös maa- ja metsätalousministeriön yksityismetsänomistajille myöntämiä metsätalouden tukia. Näillä tuetaan mm. taimikonhoitotöitä ja metsäteiden rakentamista. Metsään.fi-palvelun käyttöönoton myötä näitä tietoja tehdyistä töistä on hyödynnetty myös metsätiedon ajantasaistuksessa, mikä on parantanut tiedon laatua verrattuna aiempiin harvoin päivitettyihin paperisiin metsäsuunnitelmiin. Ajantasaistuksessa käytetään myös metsänomistajan antamia toteutustietoja.

Metsään.fi-sivuston avoimessa aineistossa ei ole henkilötietoja, eikä arvioita toimenpideehdotusten kustannuksista tai tuloista eikä Kemera-tukien saatuja euromääriä. Muutoin sivustolla on lähes kaikki tieto, mitä Metsäkeskuksella on yksityismaiden noin 14 miljoonan hehtaarin alasta, jolla on yli 10 miljoonaa metsikkökuviota. Metsähallituksen, kuntien, seurakuntien ja metsää omistavien yritysten, kuten Tornatorin, mailta Metsäkeskuksella on kuviotietoa vain vähän, sen sijaan hilatieto on kattavaa. Avoimia aineistoja voi käyttää kuka tahansa ilman rekisteröitymistä. Latausmääriä tarkasteltaessa ja yrityskontakteihin perustuvan tietämyksen pohjalta avoin tieto onkin otettu laajasti käyttöön metsäpalveluja ja puukauppaa tarjoavissa yrityksissä. Samaan aikaan tiedolle on alettu hakea lisää käyttötapoja muualtakin kuin perinteisen metsätalouden aloilta. Esimerkkeinä tällaisista aloista ovat luonnontuoteala ja erilaiset virkistys- ja harrastuskäyttötavat. Myös tässä Säätyö-hankkeessa tuotetulle tiedolle löytyy uusia käyttötapoja ja käyttökohteita.

Tietoa jaetaan Metsään.fi -sivuston avoimissa aineistoissa kolmessa eri muodossa:

1. Karttapalveluissa avointa metsätietoa voi katsella verkkoselaimella ilman erillistä paikkatietosovellusta tai tähän vaadittavaa osaamista. Tieto on ajantasaista, mutta suppeampaa kuin kohtien 2 ja 3 aineistoissa. Esimerkiksi kuviotietoja puustoista ei ole saatavilla. Tämä tieto soveltuu hyvin esimerkiksi sen tarkistamiseen, onko metsänkäyttöilmoitus tehty kohteelle, jolla aiotaan tehdä hakkuita ja onko se voimassa (https://www.metsaan.fi/karttapalvelut).

Avoimet tiedot ovat selattavissa karttapalveluna myös osoitteessa: https://kartta.paikkatietoikkuna.fi/

2. Paikkatietoaineistoissa avointa metsätietoa on saatavana erilaisina ennalta tehtyinä aineistopaketteina (geopackages). Aineistot on jaoteltu ryhmiin aineistosisällön perusteella. Aineistosisältöjä ovat esimerkiksi metsävarakuviotiedot, hilatiedot, metsien 
erityisen tärkeät elinympäristöt, metsänkäyttöilmoitukset, kemerahakemukset, jne. Toinen jaottelu on tehty aluejaon perusteella. Aineistot on muodostettu karttalehdittäin, kunnittain ja maakunnittain. Aineistopaketti ladataan omalle tietokoneelle tai palvelimelle ja käyttäjällä täytyy olla jokin sovellus, jolla voi avata aineistopaketin sekä selata ja käsitellä tietoa. Aineistopaketteja uudistetaan ja päivitetään Metsäkeskuksessa; esimerkiksi Metsävaratieto keskimäärin kerran vuorokaudessa (https://www.metsaan.fi/paikkatietoaineistot).

3. Kolmas vaihtoehto hyödyntää avoimia aineistoja on käyttää rajapintapalveluita teknisen käyttöyhteyden avulla. Rajapintojen hyödyntäminen edellyttää rajapintaa tukevaa ohjelmistoa, joka voi olla esimerkiksi paikkatieto-ohjelmisto tai selainsovellus. Rajapinnan kautta aineisto ladataan rajauksen perusteella. Tieto on ajantasaista toimenpiteiden ja kasvun laskennan yms. osalta. Metsäkeskuksen rajapinnat käyttävät kahta eri tekniikkaa. Kaikkia aineistoja on mahdollista tarkastella WMS- ja WFSpaikkatietorajapintojen kautta. Metsävarakuvioilla on lisäksi käytössä aineiston lataamiseen tarkoitettu REST-rajapinta, joka palauttaa tietoa Metsäkeskukseen metsätietostandardin mukaisena XML-sanomana (https://www.metsaan.fi/rajapinnat).

4. Lisäksi on olemassa tiedosta jalostettuja aineistoja, joista eniten käytetty on korjuukelpoisuuskartta (https://www.metsakeskus.fi/korjuukelpoisuuskartat). Nämä aineistot eivät sijaitse Metsään.fi -sivustolla, vaan löytyvät tällä hetkellä osoitteesta https://www.metsakeskus.fi/ palvelut -valikon alta. Muita aineistoja on esimerkiksi vesiensuojeluun suunniteltu https://www.metsakeskus.fi/ metsatalouden-vesiensuojelu. Nämä aineistot ovat käytettävissä karttapalvelun ja rajapinnan kautta.

\subsubsection{Luonnonvarakeskus tarjoaa avoimesti valtakunnan metsien inventointiin perustuvaa avointa tietoa}

Luonnonvarakeskuksen (Luke) keräämä metsätieto eroaa Metsäkeskuksen aineistosta ja se perustuu valtakunnan metsien inventointiin (VMI) ja inventoinnissa käytettyihin koealoihin. VMI-tietojen pohjalta tiedot yleistetään koko Suomea koskevaksi. Metsätiedon keräämisessä käytetään ns. monilähdeinventointia, jossa maastotietojen lisäksi käytetään satelliittikuvia ja muita numeerisia tietolähteitä, kuten esimerkiksi numeerisia peruskarttoja ja korkeusmalleja. Luken metsätieto on muodoltaan $16 \mathrm{~m} \times 16 \mathrm{~m}$ hilaan arvioitua tietoa, eikä sisällä toimenpide-ehdotuksia.

Valtakunnan metsien inventoinnilla seurataan Suomen metsävarojen kehitystä ja muutosta puulajeittain ja puutavaralajeittain sekä puuston vuosikasvun muutoksia, sekä muita metsiä kuvaavia muuttujia. VMI-tiedon pohjalta pystytään kertomaan esimerkiksi siitä, kuinka puuston kasvu on muuttunut vuosikymmenien kuluessa ja minne kannattaa perustaa jokin tiettyä puutavaralajia käyttävä tuotantolaitos. Tietoa käytetään metsävarojen kehityksen seurannassa valtakunnan tasolla, politiikan tukena ja erilaisiin tutkimustarkoituksiin. VMItietojen pohjalta tehdään esimerkiksi arvioita Suomen metsien hiilinieluista ja kestävistä hakkuumahdollisuuksista eri aikajänteillä.

Metsäntutkimuslaitos (Metla) (2015 alkaen Luke) kehitti valtakunnan metsien monilähteisen inventoinnin ja otti sen käyttöön vuonna 1990. Maastotietojen, satelliittikuvien ja muun numeerisen paikkatiedon avulla tuotetaan kuntakohtaiset metsävara-arviot ja karttamuotoisia metsävaratietoja. Suurimpaan osaan maata on tuotettu yhdeksän kattavaa karttateemajoukkoa ja Lappiin kahdeksan. Uusimmassa, vuoden 2017 inventoinnissa on 45 teemaa, esimerkiksi eri puulajeilla puutavaralajitilavuudet (tukki- ja kuitupuu) sekä biomassaositteet. Ensimmäinen koko maan tuote valmistettiin vuosina 1990-1994; uusimmat ovat vuosilta 2015 ja 2017. 
Metsäntutkimuslaitos (Metla) päätti marraskuussa 2012 laittaa vuoden 2009 karttamuotoiset teemat avoimesti jaettaviksi ja vuoden 2017 tulokset ovat viides vapaaseen jakeluun tuleva ja kolmas Luken tuottama karttajoukko. Jatkossa uudet teemat tuotetaan yhden tai kahden vuoden välein. Karttamuotoiset aineistot ovat rasterimuodossa, aiemmin $20 \mathrm{~m} \times 20 \mathrm{~m}$ hilassa ja nykyisin $16 \mathrm{~m} \times 16 \mathrm{~m}$ hilassa ETRS-TM35FIN-koordinaattijärjestelmässä.

Osoitteessa www.paikkatietoikkuna.fi on karttapalvelu, jossa pääsee tutkimaan Luken metsävarakarttojen sisältöä seuraavalla tavalla (esimerkkinä puuston tilavuus): Valitse valikosta Karttatasot > Maanpeite >Tilavuus, puusto yhteensä $2017\left(\mathrm{~m}^{3} / \mathrm{ha}\right)$. Sivulla http://kartta.luke.fi/opendata/valinta.html on latauspalvelu avoimelle aineistolle. Palvelu vaatii sähköpostiosoitteen, johon lähetetään latauslinkki. Rajapinta-aineistoja ei ole.

\subsection{Maanmittauslaitos tarjoaa avoimesti karttoja, ilmakuvia, kiinteistörajatietoja ja laserkeilausaineistoja}

Sivulla https://www.maanmittauslaitos.fi/kartat-ja-paikkatieto on saatavissa monenlaisia avoimia aineistoja, kuten aina uusin ilmakuva (ortokuva), kiinteistöjen raja-aineistot, erilaisia pohjakarttoja, korkeusmalleja ja niin edelleen. Aineistot toimivat rajapinnan kautta. Samat aineistot löytyvät selattavina versioina osoitteesta www.paikkatietoikkuna.fi.

Sivulla https://tiedostopalvelu.maanmittauslaitos.fi/tp/kartta $\quad$ on saatavissa Maanmittauslaitoksen yhdessä monen muun tahon, kuten Metsäkeskuksen kanssa tekemän laserkeilauksen pistepilvi avoimena aineistona. Aineisto rajataan karttarajauksella ja ladataan sähköpostiin tulevan linkin avulla. Laserkeilaus-aineisto tulee Laz-tiedostona. Maanmittauslaitos käyttää laserkeilaus-aineistoa muun muassa tarkempien maastokarttojen luomiseen. Metsäkeskus tuottaa samasta laserkeilauksen pistepilvestä yhdessä referenssikoealojen ja ilmakuvien avulla hilamuotoisen metsävaratiedon ja sen pohjalta kuviokohtaisen metsätietonsa. Museovirasto on käyttänyt laserkeilausta muinaisten asuinpaikkojen etsimisessä ja taistelupaikkojen rakenteiden, kuten juoksuhautojen kartoittamisessa. Pistepilveä käytetään todella moneen tarkoitukseen, kuten sähkölinjan vierusmetsien riskipuiden kartoittamiseen sekä kehitteillä oleviin virtuaalimetsäsovelluksiin. Laserkeilauksen avulla kerättyä tietoa on käytetty Säätyö-hankkeen tuulituhoriskianalyysissä ja korjuukelpoisuuden määrittämisessä ojaston kuivavaran selvittämisessä.

\subsection{Suomen ympäristökeskuksen avoimet aineistot sisältävät mm. kosteusindeksitiedot}

Suomen ympäristökeskus (SYKE) mm. tutkii, kerää ja hallinnoi ympäristön tilaan liittyvää tietoa. Avointa aineistoa on paljon. SYKE laskee esimerkiksi maan kosteutta kuvaavaa kosteusindeksiä. Se löytyy osoitteesta: https://www.syke.fi/fi-FI/Avoin_tieto/ Avoimet_rajapinnat/Satelliittihavaintojen_rajapinnat. Kosteusindeksiä voi hyödyntää esimerkiksi maaston kantavuuden arviointiin.

\subsection{Copernicus-ohjelma tarjoaa Euroopan ja maapallon kattavia avoimia aineistoja}

Sää- ja ilmastotietoja tarvitaan Euroopan ja maailmanlaajuisesti. Euroopassa ympäristön tilan seurantaan on perustettu Copernicus-ohjelma (https://www.copernicus.eu/fi). Ohjelman tarjoamat informaatiopalvelut ovat maksuttomasti ja avoimesti kaikkien käytettävissä. Aineistot pohjautuvat sekä satelliiteista saataviin mittaustietoihin, että maan pinnalla tehtyihin havaintoihin ja niitä hyödyntäviin mallinnuksiin. Ohjelmaa koordinoi ja hallinnoi Euroopan komissio ja sitä toteuttavat yhteistyössä jäsenvaltiot, Euroopan avaruusjärjestö (ESA), Euroopan sääsatelliittijärjestö (Eumetsat), Euroopan keskipitkien sääennusteiden keskus 
(ECMWF), EU:n virastot ja Mercator Océan. Copernicus-ohjelma tuottaa palveluita kuudelle eri sektorille: ilmakehän seuranta, meriympäristö, maakartoitus, ilmastonmuutos, turvallisuus ja hätätilanteet. Metsäbiotaloudelle tuottavat hyödyllisiä aineistoja etenkin ilmakehän seuranta, maakartoitus, ilmastonmuutos ja hätätilan hallinta.

Ilmakehän seurantapalvelut tuottavat tietoa ilmanlaadusta ja ilmakehän koostumuksesta, otsonikerroksesta ja ultraviolettisäteilystä, kasvihuonekaasujen, kuten esimerkiksi hiilidioksidin ja metaanin päästöistä, auringon säteilystä sekä ilmastopakotevaikutuksesta. Ilmakehän seurantapalvelulla tuetaan monia sovelluksia esimerkiksi terveydenhuollon, ympäristönseurannan, uusiutuvan energian, meteorologian ja ilmastotieteen aloilla (https://www.copernicus.eu/fi/palvelut/ilmakeha; $\quad$ https://www.copernicus.eu/sites /default/files/documents/Copernicus_AtmosphereMonitoring_Feb2017.pdf).

Copernicuksen maakartoituspalvelu tuottaa paikkatietoa maanpeitteestä ja sen muutoksista sekä maankäytöstä. Lisäksi tuotetaan paikkatietoa kasvillisuuden tilaa, veden kiertokulkua ja maanpinnan energiatasetta kuvaavista muuttujista (https://www.copernicus.eu/fi /palvelut/maakartoitus). Palvelu tukee esimerkiksi alueidenkäytön suunnittelua, metsänhoitoa, vesienhoitoa, maataloutta ja elintarviketurvaa, luonnonsuojelua ja ennallistamista sekä maaseudun kehittämistä. Ilmastonmuutoksen hillinnän kannalta maankäytön muutosten (LULUC) seurannan tärkeys on korostunut, ja tämä palvelu tuottaa keskeistä tietoa esimerkiksi metsien tilasta. Palvelussa löytyy, muun muassa, jopa $10 \mathrm{~m}: \mathrm{n}$ tarkkuudella tuotettuja latvustiheyden tai puutyyppien aineistoja.

Copernicuksen ilmastonmuutosta koskeva palvelu (C3S) tarjoaa luotettavaa tietoa Euroopan ja maailman ilmaston aiemmasta, nykyisestä ja tulevasta tilasta (https://www.copernicus.eu/fi/palvelut/ilmastonmuutos). Palvelussa tarjotaan parhaimpiin saatavilla oleviin tieteellisiin tietoihin pohjautuvia ilmastoaineistoja ja analysointivälineitä. Palvelun toteuttaa Euroopan keskipitkien sääennusteiden keskus (ECMWF) Euroopan komission puolesta. Palvelusta saa muun muassa kerran kuukaudessa tuotettavia vuodenaikaisennusteita useilta eri ennustuskeskuksilta, joista kaikki tuottavat parviennusteita.

Copernicuksen ilmastopalveluiden (https://climate.copernicus.eu/) keskeisiä tuotteita ovat:

- ilmastotiedotteet (https://climate.copernicus.eu/climate-bulletins)

- tehokas ilmastotietojen jakelukanava "Climate Data Store" (https://cds.climate. copernicus.eu/\#!/home)

○ Climate Data Store sisältää lukuisia aineistokokonaisuuksia (https://cds.climate.copernicus.eu/cdsapp\#!/search?type=dataset), $\quad$ jotka kuvaavat mennyttä ilmastoa kuten myös ilmastomalleihin pohjautuvia arvioita tulevasta ilmastosta.

○ Aineistot sisältävät myös johdettuja suureita, kuten esimerkiksi maa- ja metsätaloutta tukevia indeksejä (https://cds.climate.copernicus.eu/cdsapp\#!/dataset/sis-agroclimaticindicators?tab=overview) tai metsäpalovaaraa kuvaavia tietoja (https://cds.climate. copernicus.eu/cdsapp\#!/dataset/cems-firehistorical?tab=overview).

- yhteiskunnan eri toimialoja palvelevat erityisprojektit (https://climate.copernicus.eu/data-action).

Arvioitaessa menneitä säätilanteita keskeisiä tuotteita ovat niin sanotut uusanalyysit. Uusanalyysien avulla on luotu kuva ilmakehän tilasta hyödyntäen kaikkia mahdollisia säähavaintoja sekä uusimpien ilmakehämallien analyysejä. Näissä analyyseissä on hyödynnetty kaikkia mahdollisia säähavaintoja sekä ilmakehämallien analyysejä. Uusin tällainen aineisto on 
ERA5 (https://cds.climate.copernicus.eu /cdsapp\#!/dataset/reanalysis-era5-pressurelevels?tab=overview). Tässä aineistossa on kuvattu koko maapallon sääolot tunnin aikaaskeleella vuodesta 1979 alkaen. Alueellinen tarkkuus on noin $30 \mathrm{~km}$. Aineistossa ovat maanpinnan olosuhteiden lisäksi mukana olosuhteet korkeammalta ilmakehästä. Maasovelluksia varten on tästä vielä tarkennettu ERA5-Land, jossa alueellinen tarkkuus on noin $9 \mathrm{~km}$. Tarkennuksen lisäksi tässä versiossa on mukana enemmän maasovelluksien kannalta mielenkiintoisia muuttujia kasvillisuuden, järvien ja hydrologian tarkempaan analyysiin.

Meneillään olevissa myrskytutkimuksen hankkeissa, kuten mm. ERA4CS WINDSURFER ja MONITUHO, ERA5-aineistolla on selvitty mm. menneen ilmaston vuosikymmenskaalan vaihtelua Pohjois-Atlantin ja Euroopan alueella (Laurila ym., 2020). Kesän 2020 Aila-myrskyn osalta, ERA5:n puuskatuulen nopeuksia verrattiin Ilmatieteen laitoksen puuskahavaintoihin ja tutkittiin ERA5:n maa-meri-jakauman ja tuulen suunnan merkitystä, sillä ERA5 puuskatuulien huomattiin olevan parempia kuin varsinaisten keskituulihavaintojen (Rantanen et al., 2020).

\subsection{Vaikutustietokannat kokoavat yhteen sääilmiöiden aiheuttamat yhteiskunnalliset vaikutukset}

Kun ennustetaan voimakkaita sääilmiötä, niin on entistä tärkeämpää arvioida myös ilmiöiden vaikutuksia. Kun vaikutuksia arvioidaan tehokkaasti, voidaan myös entistä paremmin suunnitella ja ottaa käyttöön tehokkaita toimia ilmastonmuutoksen vaikutuksiin sopeutumiseksi. Vaikutustietokannan tavoitteena on saada koottua jonkin ilmiön yhteiskunnalliset vaikutukset siten, että tietoja on helppo analysoida ja kehittää edelleen yhteiskunnan valmiutta kohdata haitallisia ilmiöitä, kuten voimakkaat sääilmiöt.

Vaikutustietokantaa kehitetään Ilmatieteen laitoksella kahdessa projektissa, jotka liittyvät voimakkaiden sääilmiöiden aiheuttamiin tuhoihin. Vaikutustietokantoja kehitetään myös eurooppalaisena yhteistyönä hankkeessa Loss Data Enhancement for DRR\&CCA management (LODE) (https://www.lodeproject.polimi.it/). EU-LODE-hankkeessa (2019-2021) kehitetään luonnononnettomuuksien aiheuttamien vahinkojen tietojärjestelmää. Metsätalouden toimijoista Suomen metsäkeskus on toimittanut esimerkkiaineistoja myrskyvahingoista. Tarkastelun kohteena ovat olleet erityisesti vuoden 2011 Tapani-myrskyn vaikutukset. LODEhankeessa laaditaan malli yleisestä, useille luonnononnettomuuksien vahingoille soveltuvasta tietojärjestelmästä.

Toinen menossa oleva hanke on Huoltovarmuuskeskuksen rahoittama Sää- ja ilmastovaikutustietokannan kehittäminen (SILVA) -hanke. SILVA-hankkeessa kartoitetaan tietokantaan soveltuvien tietoaineistojen laajuus sekä kuvataan tietojen hyödyntämisen edut ja haasteet. Hankkeessa myös kerätään hyödyntämiskelpoiset aineistot ja järjestetään ne tietokantaan sopiviksi. Optimaalinen tietokantarakenne selvitetään käyttötapausten avulla, ja rakenteen toimivuus varmistetaan testaamalla. Lisäksi hankkeessa selvitetään kyselyn avulla, minkälaiset vaikutusennusteet olisivat varautumisen näkökulmasta hyödyllisimpiä. Kysely lähetetään vaikutustietojen lähdetahoille ja tietokannan tuloksista potentiaalisesti hyötyville asiakkaille. Saatujen vastausten ja muodostetun tietokantarakenteen perusteella luodaan vaikutusennusteen konsepti, johon pyydetään palautetta pieneltä joukolta asiakkaita.

SILVA-hankkeessa sään aiheuttamia vaikutuksia on kerätty tietokantaan kahdeksasta eri lähteestä, jotka edustavat pelastustoimen, meripelastustoimen, energiajakelun, ilmailun sekä vakuutusalan kokemia vaikutuksia. Erityisesti pelastustoimen ja energiajakelun vaikutustiedot liittyvät merkittävässä määrin puiden kaatumisiin. Useimmat näistä tietolähteistä ovat koko maan kattavia ja yhtenäisten aikasarjojen pituudet ovat viidestä noin 20 vuoteen. 


\section{Säätyö-hankkessa kehitettiin uusia metsäbiotaloutta tukevia palveluita}

- Hankkeessa kehitettiin lumituhoriskin arviointimallia lumituhoriskialueiden yksityiskohtaiseksi kartoittamiseksi.

- Hankkeessa kehitettiin puiden korjuuolosuhteiden seuranta- ja ennustepalvelu.

- Hankkeessa kehitettiin tuulituhoriskityökalun testiversio, jonka avulla voidaan laskea puuston tuulituhoon tarvittavia tuulennopeuksia.

Ilmastonmuutos lisää metsiin kohdistuvia riskejä ja voi myös hankaloittaa puiden korjuuoloja, kun routa vähenee ja sademäärät kasvavat. Metsätaloudessa tarvitaan siis tehokkaita keinoja sopeutumisen tueksi. Säätyö-hankkeessa kehitettiin kolmea uutta tuotetta metsätalouden sopeutumisen tueksi: 1) lumituhoriskialuiden yksityiskohtainen kartoitus, 2) puiden korjuuolosuhteiden seuranta- ja ennustepalvelu ja 3) tuulituhoriskin sekä toteutuneiden tuulituhojen kartoitus.

\subsection{Puiden lumituhoriskin kartoituksessa otetaan huomioon säätekijöiden lisäksi metsän ominaisuudet ja maaston korkeusvaihtelut}

Tuulituhojen lisäksi yleisimpiä metsissämme esiintyviä sään aiheuttamia puustovaurioita ovat lumen aiheuttamat puustovauriot. Ne vaihtelevat alueellisesti ja myös talvesta toiseen. Solantie (1994) esitti arvion, jonka mukaan merkittäviä lumituhoja esiintyy Suomen metsissä alueesta riippuen keskimäärin noin 3-17 vuoden välein. Lumituhojen esiintyminen on hyvin riippuvaista paikallisista maastonmuodoista siten, että ympäristöään korkeammilla maastonkohdilla tuhoja esiintyy eniten. Altteimpia lumituhoille ovat siis Itä- ja PohjoisSuomen vaarojen lakiosien metsät.

Puuston lumikuormaa voidaan arvioida säätietojen avulla (Lehtonen ym., 2014). Keskeisiä lumen kertymää selittäviä säätekijöitä ovat sade (eri olomuodoissaan), ilman kosteus, ilman lämpötila ja tuulen nopeus. Lehtosen ym. (2014) mallissa puiden oksille kertyvä lumikuorma jaotellaan neljään tyyppiin, jotka ovat kuiva lumi, märkä lumi, jäätynyt lumi ja ilmasta oksiin kertyvä huurre.

Lumikuormamallin perusteella voidaan arvioida esimerkiksi puiden oksille kertyvän talven suurimman lumikuorman toistuvuustasoja (kuva 4.1). Näin tehdyn analyysin mukaan suurimman lumituhoriskin alueilla Itä- ja Pohjois-Suomessa talven suurimman lumikuorman 10 vuoden toistuvuustaso on noin $60 \mathrm{~kg} \mathrm{~m}^{-2}$ ja 20 vuoden toistuvuustaso jopa lähes $100 \mathrm{~kg} \mathrm{~m}^{-2}$ (kuva 4.1). Lounais-Suomen vähälumisilla alueilla vastaavat toistuvuustasot ovat noin 20 $40 \mathrm{~kg} \mathrm{~m}^{-2}$.

Ilmaston lämpenemisen seurauksena talven suurimpien lumikuormien arvioidaan kasvavan niillä alueilla, joilla ne jo nykyisinkin ovat suurimmat, eli Pohjois-Karjalan ja Kainuun vaaraseuduilta Lappiin ulottuvalla alueella. Etelä- ja Länsi-Suomessa lumikuormat puolestaan pienenevät (Lehtonen ym., 2016). Lumikuormien kasvuun itärajan pinnassa ja PohjoisSuomessa vaikuttaa sekä se, että puihin kertyy huurretta entistä enemmän kuin myös se, että märkää lunta sataa aiempaa useammin.

Lehtonen ym. (2014) huomioivat lumikuorman kertymää kuvaavassa mallissa säätekijät mutta eivät metsän ominaisuuksia. Säätyö-hankkeessa Luonnonvarakeskus kehitti lumituhoriskin 
arviointimenetelmää eteenpäin siten, että lumituhojen riskiä arvioitaessa huomioidaan säätekijöiden lisäksi metsän ominaisuudet ja maaston korkeusvaihtelut (Suvanto ym., 2020). Mallia käyttäen on laadittu samantyyppinen karttatuote kuin aiemmin julkaistiin tuulituhoriskien esittämistä varten (https://metsainfo.luke.fi/fi/tuulituhoriskikartta) (kuva 4.2). Tausta-aineistona mallin kehitystyössä on käytetty VMI10-12 maastohavaintoja lumituhoista vuosilta (2005-2018). Lumituhoista tarkasteltiin vain niitä, jotka olivat syntyneet enintään viisi vuotta ennen VMI-koealan mittausta. Malli testattiin aineiston 20 \%:n otoksella VMI12koealoista, jotka eivät olleet mukana mallin sovituksessa. Lopulliseksi malliksi valittiin tuhoriskiä kuvaava yleistetty lineaarinen malli (GLM), jonka ennusteet ja selitysvoima vastasivat joustavamman GAM-mallin (Generalized additive model) ennustetta. Useiden testien ja iteraatioiden jälkeen mallin selittäjiksi päätyi Ilmatieteen laitoksen mallilla (Lehtonen ym., 2014) ennustettu lumikuorman määrä puun latvuksessa, kertymä, maaston korkeus ja sen vaihtelu (korkeus merenpinnasta, suhteellinen korkeus 1 km:n säteellä), puuston ominaisuudet (metsikön valtapuulaji, keskimääräinen rinnankorkeusläpimitta ja puuston pohjapinta-ala). Metsänhoitoa kuvaavat tekijät (harvennus) eivät tulleet mallissa merkittäviksi, joka voi johtua käytetyn tiedon luonteesta, tai siitä, että harvennusten merkitys lumituhoriskille ei ole niin suuri kuin usein on oletettu.

Mallia kehitettäessä tutkittiin erilaisten ilmasto-olosuhteiden vaikutusta ennusteiden luotettavuudelle. Sitä varten laadittiin GLM-mallista kolme versiota, joissa selittäjinä olivat 1) abioottiset ilmastoon ja sijaintiin liittyvät tekijät, ja 2) bioottiset tekijät, eli metsän rakenteeseen liittyvät tekijät ja 3) kummatkin edellä mainitut tekijät. Testeissä havaittiin, että parhaan mallin tuotti malliversio, jossa molemmat tekijäryhmät ovat mukana. Abioottisten tekijöiden merkitys kasvoi äärimmäisissä lumikuormaolosuhteissa (talvi 2017-2018). Tällöin malli, jossa oli vain abioottiset tekijät mukana, selitti tuhoriskiä miltei yhtä hyvin kuin malli, jossa kaikki tekijät olivat mukana. Tavallisina talvina bioottisten tekijöiden merkitys korostui. Lopulliseksi malliksi valittiin malli, jossa kaikki tekijät olivat mukana. Se ennusti lumituhoja erinomaisesti kaikissa sääolosuhteissa. Mallia testattiin VMI-otoksen lisäksi myös Metsäkeskuksen metsänkäyttöilmoituksilla vuoden 2017-2018 aineistolla, jolloin lumituhoja sattui erityisen paljon Itä-Suomessa.

Mallin avulla laadittiin riskikartta lumituhoista (kuva 4.2), joka kuvaa keskimääräisiä lumituhoriskejä Suomessa pidemmällä ajanjaksolla vuoden 2018 metsärakenteella (MVMIkartta, 2018). Lumikuormamuuttujaksi kartalle laskettiin jokaiselle kartan $16 \mathrm{~m} \times 16 \mathrm{~m}$ pikselille viiden vuoden toistuvuusjaksolle ennustettu maksimilumikuorma pidemmästä aikasarjasta (1990-2020) talven maksilumikuormakarttoja (Lehtonen ym., 2014).

Laskenta tehdään $16 \mathrm{~m} \times 16 \mathrm{~m}$ hilaruudukossa tai lohkoittain. 
2 vuotta

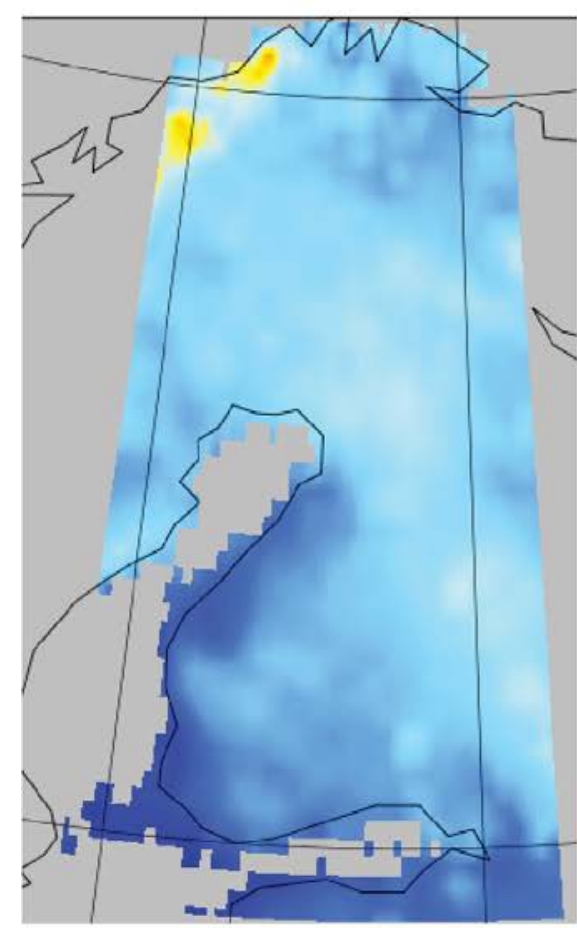

5 vuotta

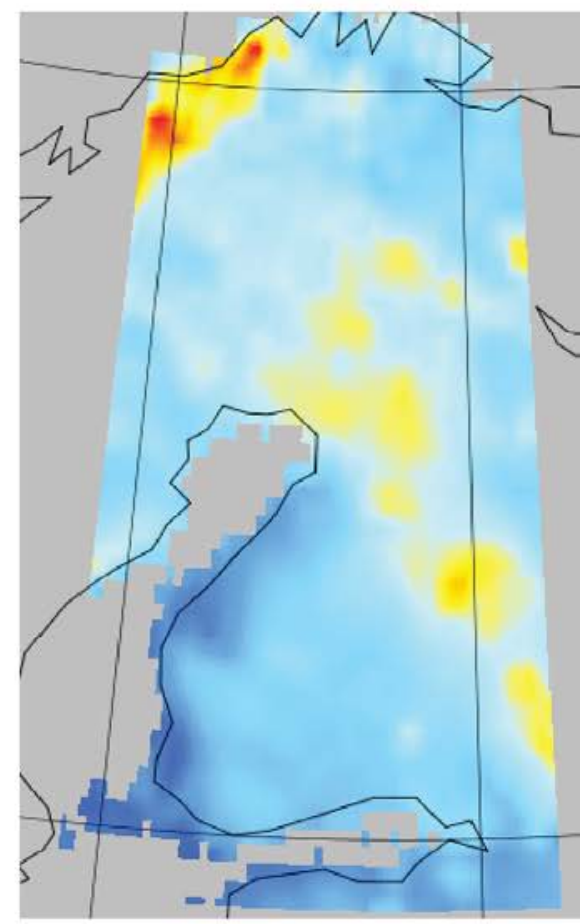

Lumikuorma $\left(\mathrm{kg}^{2} \mathrm{~m}^{-2}\right)$
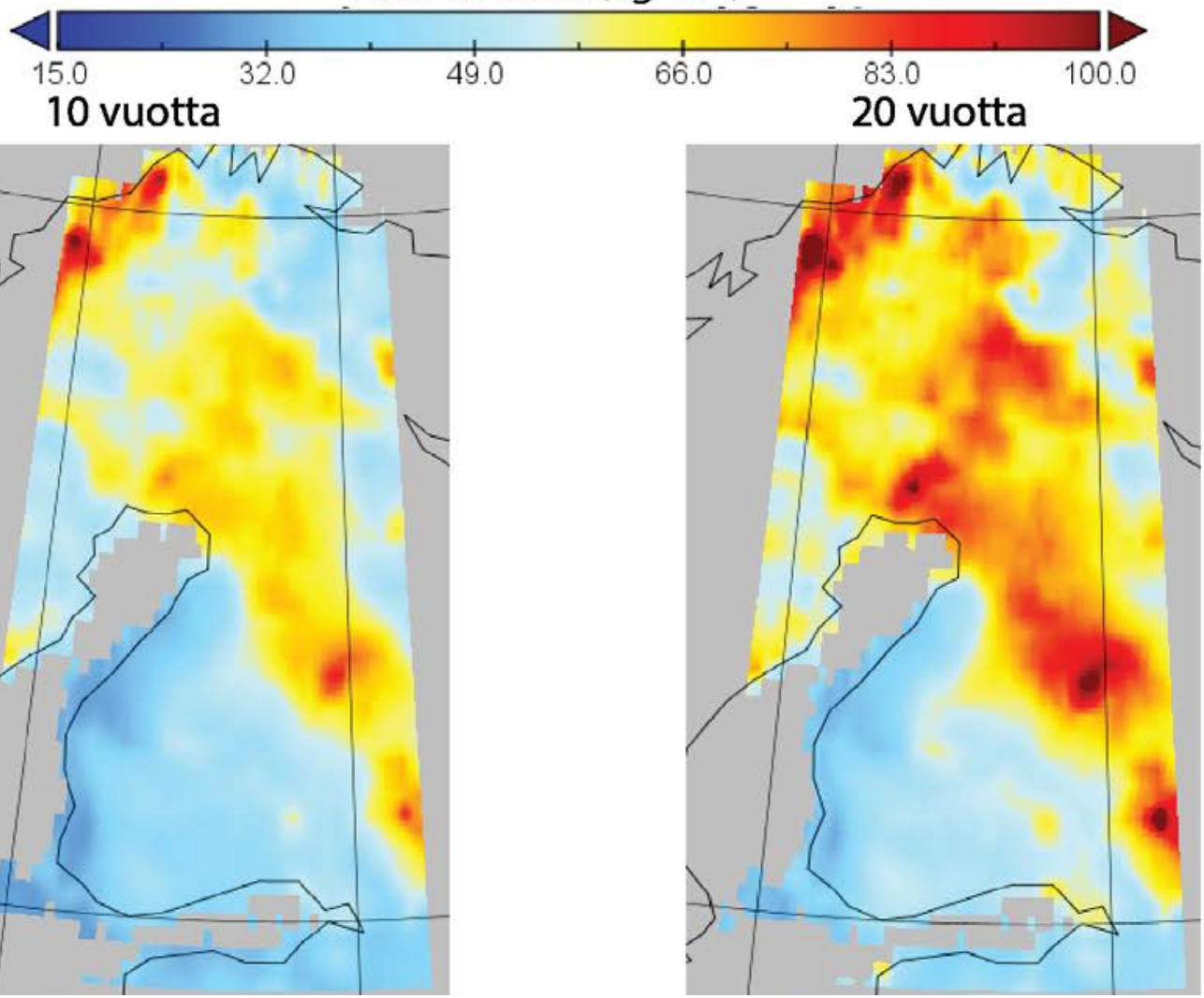

Kuva 4.1. Talven suurimman lumenkertymän 2, 5, 10 ja 20 vuoden toistuvuustasot laskettuina jakson 1990/91-2019/20 ERA 5 aineistosta Lehtonen ym. (2014) esitellyllä menetelmällä. Sinisen sävyt kuvaavat pientä lumikuormaa, keltainen väri keskisuurta lumikuormaa ja punaisen eri sävyt erittäin suurta lumikuormaa. Suurimman lumituhoriskin alueet sijaitsevat Itä- ja Pohjois-Suomessa. 


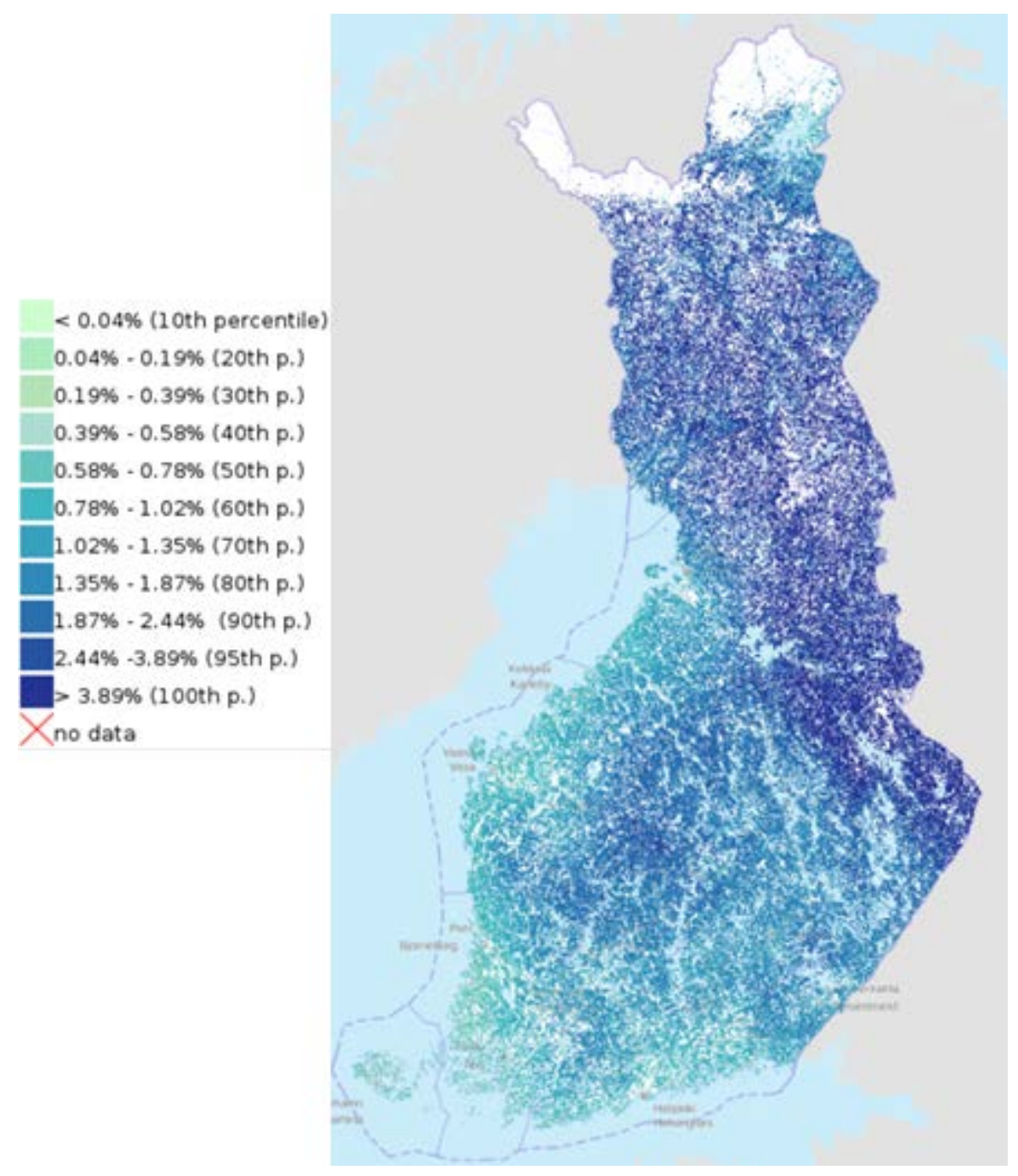

Kuva 4.2. Keskimäärinen lumituhoriski Suomen metsissä prosentteina. Laskettu Suvannon ym. (2020) menetelmällä. Mitä sinisempi väri, sitä suurempi riski.

\subsection{Maaston kantavuuden arviointia ja ennusteita varten kehitettiin uusi palvelu}

4.2.1 Maaston kantavuus ja puuston korjuukelpoisuus

Suomessa lähes kaikki puunkorjuu toteutetaan ns. tavaralajimenetelmällä, missä hakkuukone kaataa, karsii ja katkoo puut määrämittaisiksi tavaralajeiksi. Katkottu puutavara kootaan kuormatraktorilla tienvarsivarastolle, mistä puut kuljetetaan tuotantolaitoksiin puutavaraautoilla. Puuta tarvitaan tasaisesti ympäri vuoden, joten korjuuseen ja kuljetukseen liittyvä logistiikka vaatii toimintojen tehokasta suunnittelua. Tämä takaa myös sen, että puuhuoltoon sitoutuneet resurssit ovat tehokkaassa käytössä ja kausivaihtelu mahdollisimman vähäistä.

Puunkorjuun suunnittelun kulmakivinä on kulloinenkin puunkäyttö, leimikkovaranto ja korjuuresurssit. Varannossa on sekä ympärivuotiseen että kesäaikaiseen puunkorjuuseen soveltuvia kohteita. Heikoimmin kantavat kohteet voidaan korjata vain talviolosuhteissa. Suunnittelutyön tavoitteena on suunnata ja ajoittaa korjuuoperaatiot niin, että myös heikommin kantavien kohteiden korjuuoperaatiot saadaan toteutettua mahdollisimman pienin maastovaurioin. 
Korjuukoneiden aiheuttamat urapainumat voivat vaurioittaa metsään kasvamaan jäävää puustoa. Vaurioituneet puut ovat alttiita esimerkiksi juurikäävän aiheuttamille metsätuhoille (Pohjankukka ym., 2016) ja kaatuvat helpommin kovalla tuulella, jos juuria on katkennut.

Hienojakoisimmat ja kosteimmat kivennäismaat ja osa turvemaista soveltuu vain talviaikaiseen puunkorjuuseen. Puiden talvikorjuun kannalta maan kantavuus arvioidaan riittäväksi kaikilla turvemailla, jos roudan paksuus on vähintään $20 \mathrm{~cm}$ tai ja/tai lunta on vähintään $40 \mathrm{~cm}$ (Eeronheimo 1991; Lehtonen ym., 2018).

Sulan maan aikana keskeisin kantavuusolosuhteiden vaihteluun vaikuttava tekijä on maan kosteus. Korjuukohteiden kosteustasoissa on sekä pysyviä että säätilanteesta johtuvia eroja. Staattisten erojen taustalla vaikuttavat paikalliset olosuhteet, kuten maaperä, kasvipeite, pohjaveden korkeus ja ojitus. Keskeiset maankosteuteen vaikuttavat säätekijät ovat sademäärä ja haihdunta.

Hakkuualalla kasvavan puuston määrä vaikuttaa erityisesti turvemailla useammalla tavalla maaston kantavuuteen. Runsaspuustoisilla turvemailla ajouralle saadaan paljon metsäkonetta kantavaa havutusta. Myös juuristo lisää kantavuutta. Puusto myös haihduttaa vettä runsaasti ja kuivattaa tätä kautta kasvukaudella maaperää. Jos turvemaan hakkuualueella on vaihtelua puuston määrässä, vähäpuustoisimmat kohdat ovat riskialttiimpia ajourapainumille.

Metsämaan pysyvien ja hitaasti muuttuvien olosuhdetekijöiden hallinta on helpottunut viime vuosina Arbonaut Oy:n laatimien ja Metsäkeskuksen julkaisemien korjuukelpoisuuskarttojen myötä. Kun säästä riippuvat muuttujat - maan kosteus, routa ja lumipeite - yhdistetään näihin staattisisiin paikkatietoihin, on mahdollista seurata ja ennakoida kantavuusolosuhteiden kehittymistä sääolojen muuttuessa (kuva 4.3).

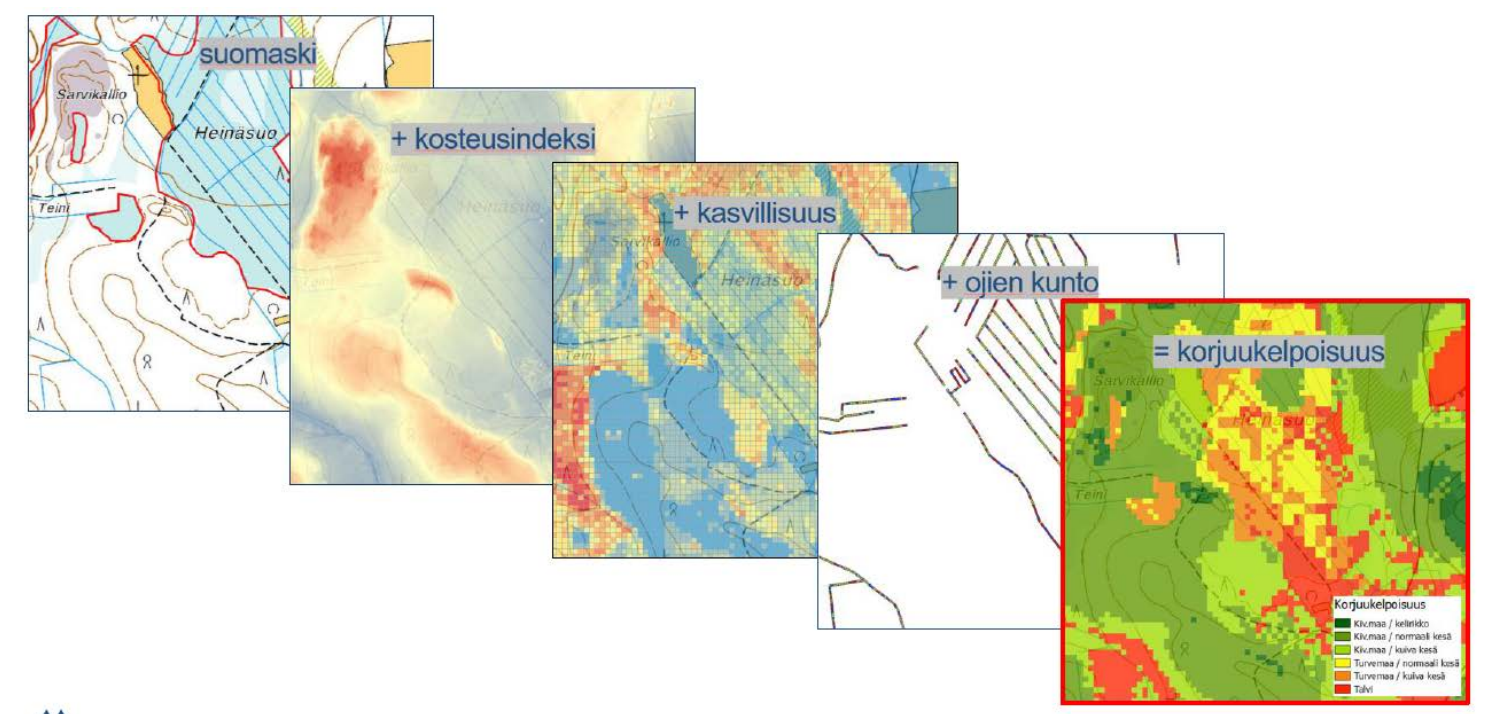

Kuva 4.3. Staattinen korjuukelpoisuuskartta laaditaan yhdistämällä eri aineistoja: maaperätiedot, kosteusindeksi, kasvillisuus ja ojien kunto.

Korjuukelpoisuuskarttoihin perustuvan paikkatietoanalyysin perusteella kesäaikaiseen puunkorjuuseen soveltuu kuivana kesänä noin 90\% kivennäismaanpinta-alasta ja normaalina kesänä noin kaksi kolmannesta (67\%). Turvemailla vastaavat osuudet ovat 63\% ja yksi viidesosa (21\%). Sää- ja paikkatietoa yhdistämällä pyritään tunnistamaan kohteet ja ajankohdat, joissa kesäaikainen puunkorjuu on mahdollista (kuva 4.4) 


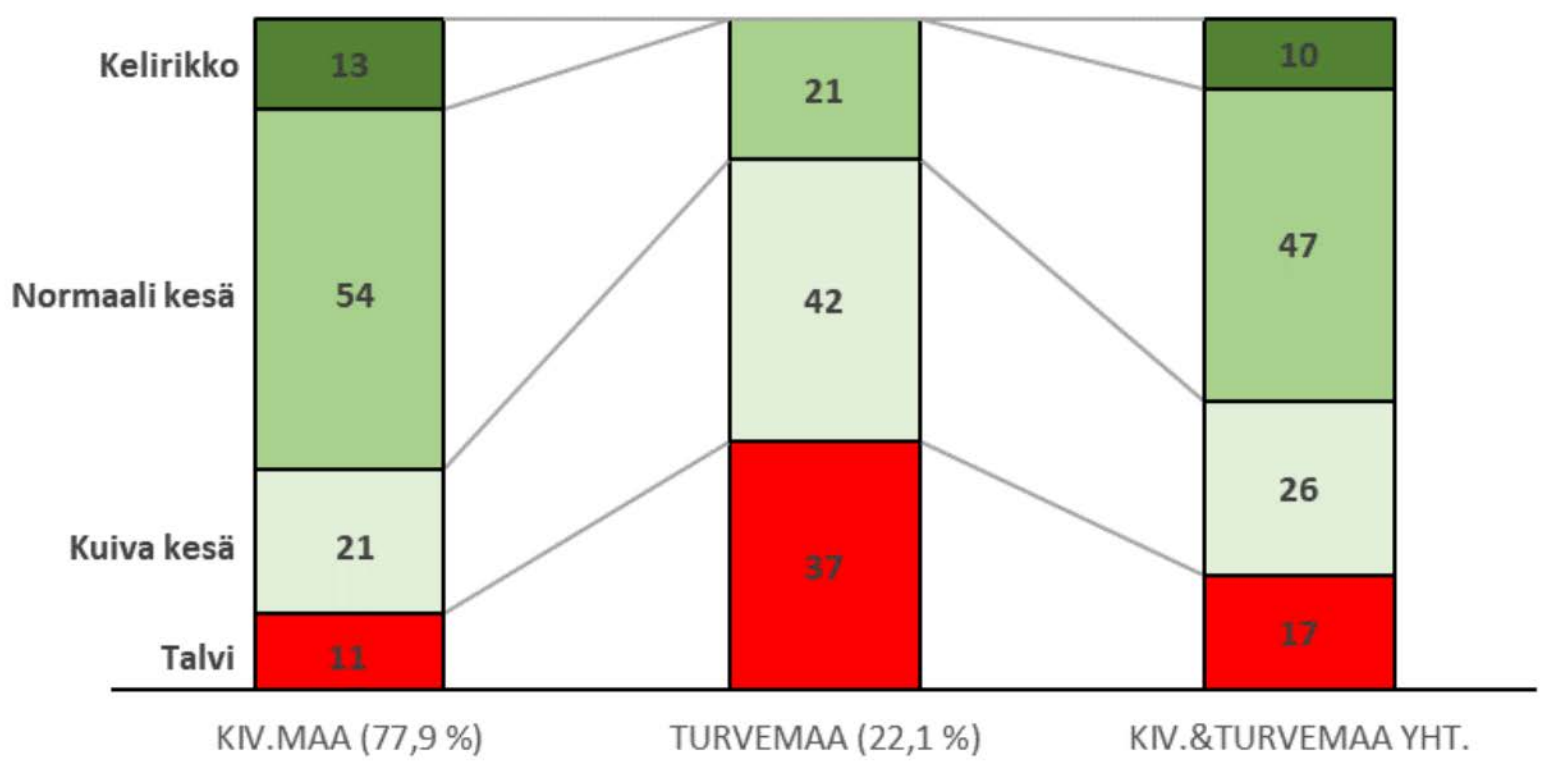

Kuva 4.4. Kivennäis- ja turvemaiden korjuukelpoisuusjakaumat.

\subsubsection{Uusi korjuukelpoisuuspalvelu tuottaa tilanne- ja ennustetietoa kivennäismaan pintakerroksen kosteudesta}

Säätyö-hankkeessa on kehitetty uusi palvelu, joka tuottaa tilannetietoa ja ennusteen maan pintakerroksen kosteudesta puoliavoimella kivennäismaalla. Tuloksena on eräänlainen indeksiluku, joka summaa pienalueen sadanta- ja haihduntatiedot. Indeksiä voidaan hyödyntää myös turvemaiden kosteustilanteen arvioinnissa.

Palvelussa tarkasteltavan maakerroksen paksuudeksi valittiin $28 \mathrm{~cm}$. Tämän uskotaan kuvaavan kantavuusolosuhteita paremmin kuin esimerkiksi metsäpalovaaran arvioinnissa käytettävä $6 \mathrm{~cm}: n$ paksuisen kerroksen kosteus. Valintaa puolsi myös se, että Euroopan keskipitkien sääennusteiden keskuksesta (ECMWF) saadaan ennusteita tämän paksuisen kerroksen kosteudelle. Säätyö-hankkeessa kehitettyä ennustepalvelua sivuaa, hyödyntää ja täydentää toinen Ilmatieteen laitoksen ja Metsätehon yhteistyöhanke nimeltään HarvesterSeasons (https://harvesterseasons.com/). Tämä palvelu rahoitettiin Copernicus Climate Change Service (C3S) Use Case palvelusopimuksella ja osana Horisontti 2020 -hanketta E-shape. HarvesterSeasons-palvelu hyödyntää pitkiä, reilun kuuden kuukauden päähän ulottuvia ennusteita maaston kantavuusolosuhteiden arvioinnissa Säätyö-hankkeen lyhyiden ennusteiden lisäksi.

Palvelussa esitetty kymmenen vuorokauden ennuste maankosteudelle on laskettu ns. metsäpaloindeksimallilla (Vajda ym., 2014), jossa hyödynnetään sade-, lämpötila-, ilmankosteus-, tuuli- ja auringonsäteilyhavaintoja. Analyysin ja ennusteen alueellinen tarkkuus on $10 \mathrm{~km} \times 10 \mathrm{~km}$. Ennusteet lasketaan päivittäin (kello 11 Suomen kesäaikaa, kello 10 normaaliaikaa). HarvesterSeasons-ennusteessa esitetään myös numeerisen sääennustemallin ns. parviajoon pohjautuva arvio tilanteen kehittymisestä reilun kuuden kuukauden ajalle tulevaisuuteen. Parviajossa tehdään 51 ennustetta samalla ennustemallilla, mutta ennusteiden lähtötilanne poikkeaa hieman toisistaan. Jokaista ennustetta parannetaan ERA5-Land datojen avulla huomioimalla näiden vuosien 2000-2019 kuukausikeskiarvojen eroja samalle periodille tehtyjen saman mallin parviajojen vastaaville arvoille. Tämä on tarpeen, koska vuodenaikaisennusteita jaetaan noin $100 \mathrm{~km} \times 100 \mathrm{~km}$ hiloissa, mikä ei edusta toivottua tarkkuutta, ja malleissa on myös harhaa mallin vaativien asetuksien vuoksi. Harhan korjaus tuo 
aineiston noin $9 \mathrm{~km}$ erotuskykyyn ja tuo tietoihin vahvasti mukaan paikallisen ilmaston ominaisuudet. Parviennusteiden avulla saadaan laskettua todennäköisyysarvio tilanteen kehittymiselle. HarvesterSeasons-palvelussa hyviä tai huonoja kelejä ennustetaan kun $90 \%$ parven jäsenistä on yhtä mieltä siitä, että vuodenajalle kriittinen olosuhdetekijä (kosteus, lumen tai routakerroksen paksuus) ylittää tai alittaa ennalta asetetun kynnysarvon (kuva 4.5).

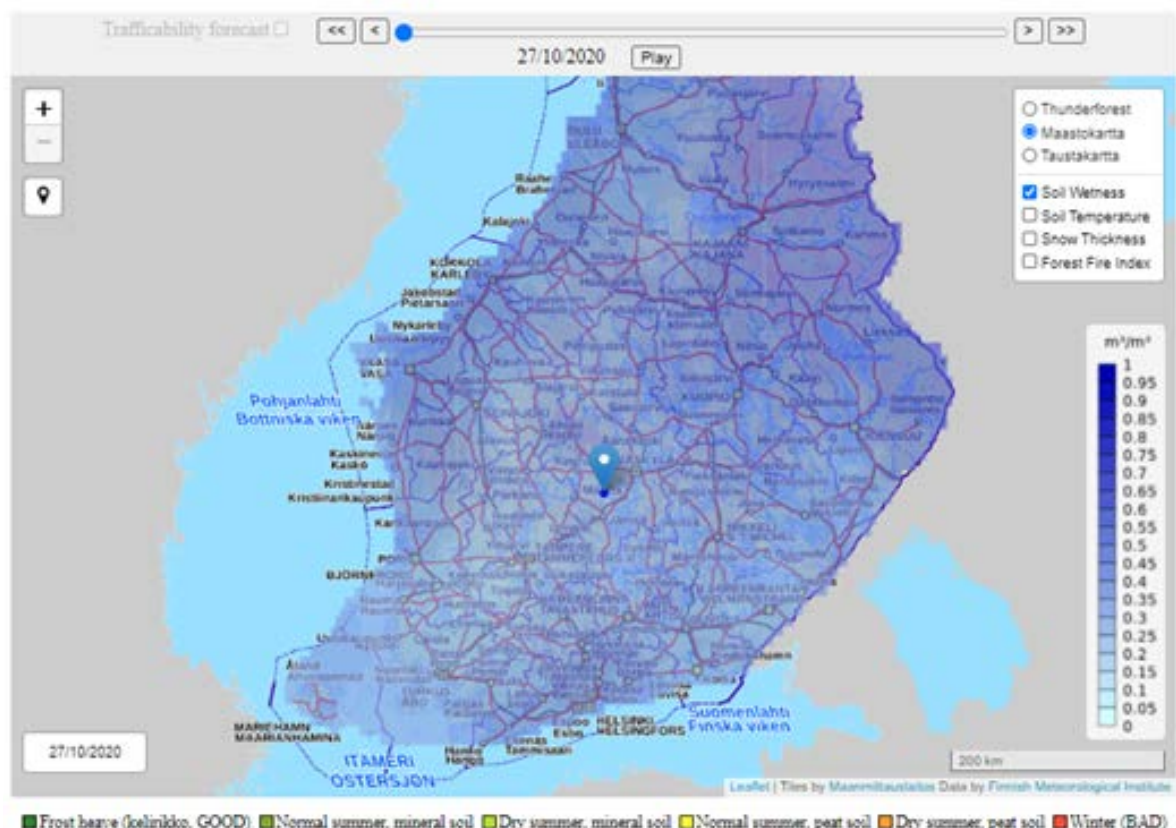

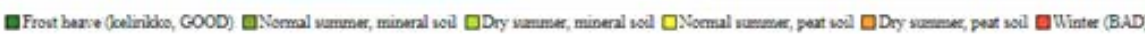

- sI

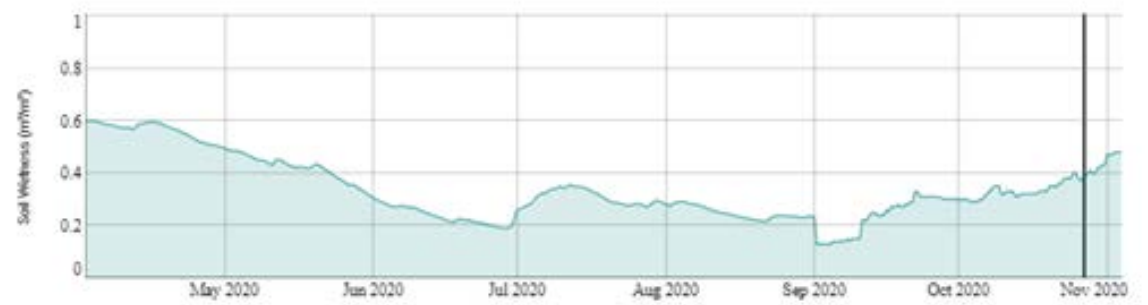

Kuva 4.5. Näkymä HarvesterSeasons-hankkeessa tuotetusta testipalvelusta, jossa hyödynnetään Säätyö-hankkeessa kehitettyä kosteusindeksiä. Kuvan yläosassa on esitetty maankosteus kartalla $\mathrm{m}^{3} / \mathrm{m}^{3}$ ), jossa tummemman sinisen sävyt kuvaavat kosteampia alueita. Kuvan alaosan graafi taas esittää maankosteuden aikajanalla, tässä kahdeksan kuukauden ajalta.

Kosteustietoon perustuvan kantavuusennusteen osuvuutta tutkitaan muissa hankkeissa vertaamalla sitä kesäkaudella 2020 korjattujen leimikoiden toteumatietoihin. Tietoja on kerätty kesän ja syksyn aikana yhteensä 130 korjuukohteesta. Toteumatiedot sisältävät tarkan paikkatiedon lisäksi korjuuajankohdan ja sanallisen arvion kantavuusolosuhteista. Tulosten vertailun pohjalta arvioidaan, soveltuuko Säätyö-hankkeessa tuotettu kosteustieto operatiiviseen käyttöön ja mitkä kosteustasot indikoivat parhaiten sitä, että korjuukelpoisuudeltaan ns. kuivan tai normaalin kesän kohteiksi luokitellut kuviot kantavat korjuukoneet. Kynnysarvotarkastelu tehdään erikseen kivennäis- ja turvemailla.

Säätyö-hankkeessa testattiin kuukauden keskimääräisiä oloja kuvaavien yhden, kahden ja kolmen kuukauden päähän yltävien ennusteiden käytettävyyttä. Ennusteissa esitettiin arvio sille, miten maan kosteus tulisi poikkeamaan tarkasteltavan kuukauden keskimääräisestä maan kosteudesta. Kuukausiennusteiden yleistä laatua testattiin vertaamalla ennustettua 
maankosteutta hilaan analysoituun maankosteuteen. Analyysinä käytettiin Euroopan keskipitkien sääennusteiden keskuksen (ECMWF) ERA5-uusanalyysiä ja ennusteina ECMWF:n menneisyyteen tehtyjä ennusteita (reforecasts) vuosille 1981-2016. Kuvassa 4.6 kuvataan ennusteen laatua käyttäen CRPSS-metriikkaa (continuously ranked probability skill score). CRPSS kuvaa menetelmän ennustuskykyä (skill) suhteessa vertailuaineistoon. Täydellinen ennuste saisi arvon yksi, ja ennuste, joka ei ole ilmastollista keskiarvoa parempi, saa arvon nolla. Ennen CRPSS:n laskemista ennusteista on poistettu systemaattinen virhe ja ennusteiden todennäköisyysjakauman leveyttä on korjattu (ks. tarkemmin Hyvärinen ym., 2020).
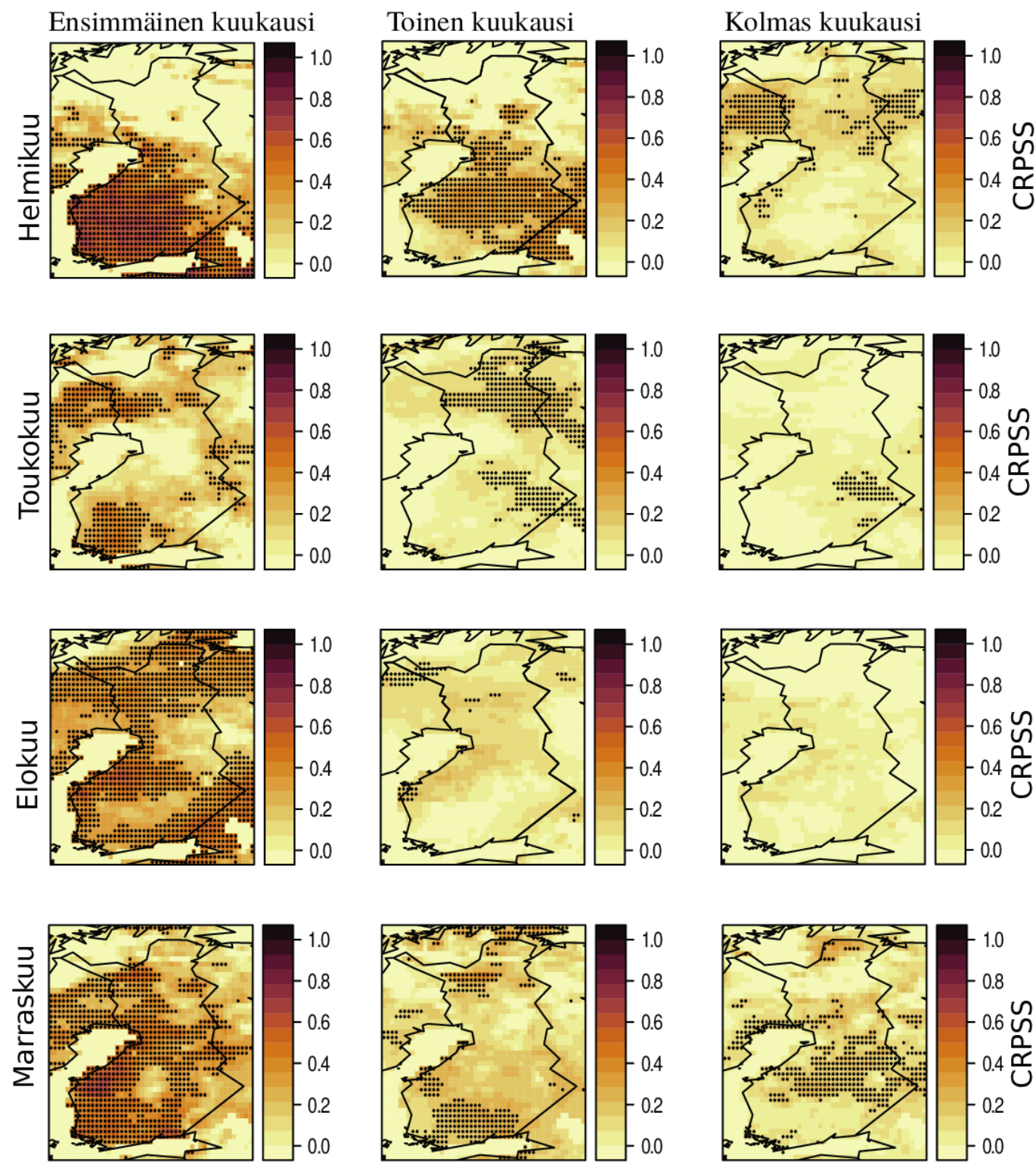

Kuva 4.6. Maankosteusennusteen ennustekyky CRPSS-metriikalla laskettuna vuosille 19812016 (Hyvärinen ym., 2020). Ennusteena on käytetty ECMWF:n ennustetta ja vertailuarvo on saatu ERA5-uusanalyysistä. Täydellinen ennuste saisi arvon yksi (tummin väri) ja ennuste, joka ei ole ilmastollista keskiarvo parempi, saa arvon nolla (vaalein väri). Kuvassa kuukaudet (helmikuu, toukokuu, elokuu ja marraskuu) kertovat sen mille kuukaudelle ennuste laadittiin. Kuvan yläreunan teksti, kuten "Ensimmäinen kuukausi”, kertoo puolestaan, kuinka monta kuukautta ennen ennusteen voimassaolohetkeä se on laadittu. Arvot, jotka poikkeavat tilastollisesti merkitsevästi nollasta, on merkitty pisteillä. 
Tulokset osoittavat, että ennusteet ensimmäiselle kuukaudelle ovat suurimmassa osassa maata parempia kuin klimatologinen ennuste. Pidemmissä ennusteissa talvikuukausien ennusteet ovat jonkin verran parempia kuin keväällä ja kesällä tehdyt ennusteet. CRPSS kuvaa ennusteiden yleistä laatua, ja niiden lopullinen sopivuus korjuukelpoisuuspalvelulle vaati loppukäyttäjän asiantuntemusta. Lisäksi vaikka aineistoa on 36 vuodelta, on aineisto toisaalta aika pieni: kun lasketaan esimerkiksi helmikuun keskivirhe yhdessä hilapisteessä, saadaan 36 vuodesta vain 36 pistettä. Tutkimuksessa (Hyvärinen ym., 2020), johon kuva 4.6 perustuu, näistä vuosista puolet käytettiin tilastollisen mallin opetukseen ja toiset puolet validointiin. Erilaisten ennusteen jälkiprosessointimenetelmien vertailu olisi myös hyödyllistä.

\subsection{Hankkeessa kartoitettiin puuston tuulituhoriskiä}

Matalapaineiden aiheuttamat myrskyt ja kesäisin ukkosen aiheuttamat rajuilmat ovat suurimpia metsätuhoja Suomessa aiheuttavia sääilmiöitä. Esimerkiksi viime vuosien laajimmat metsätuhot aiheuttaneet kesän 2010 rajuilmat aiheuttivat yhteensä noin 8 miljoonaa kuutiota metsätuhoja. Laajat metsätuhot aiheuttavat usein puun ylitarjontaa, joka laskee hintatasoa. Tuulituho alentaa puutavaran arvoa eri tavoilla. Puunkorjuu tuulituholeimikossa on kalliimpaa, koska se on hitaampaa ja vaarallisempaa ja puuta kerätään usein sieltä täältä laajalta alueelta. Tuulituho aiheuttaa myös usein puun sisäiseen rakenteeseen vaurioita. Sisäisten vaurioiden ja pirstoutumisen vuoksi osa tukkikokoisesta puutavarasta muuttuu tuulituhohakkuussa kuitupuuksi, jonka arvo on noin kolmasosa tukkipuun hinnasta. Tukkikokoinen puu ei myöskään kelpaa sahatavaraksi, jos siihen tulee sinistäjäsienten aiheuttamaa sinistymää. Lämpimällä ja kostealla säällä sinistyminen alkaa hyvin nopeasti. Tällaisessa tilanteessa puutavara siirtyy ensin tukista kuitupuuksi, ja jos kuollut puu ehtii pilaantua enemmän, se ei kelpaa enää kuitupuuksi vaan soveltuu lopulta vain energiakäyttöön. Tuulituhot aiheuttavat taloudellisia tappioita myös kasvutappioiden muodossa ennenaikaisten hakkuiden vuoksi tai jos puusto menee tuhon vuoksi harvaksi. Tuulituhon seurannaisvaikutuksena voi tulla lisääntyneitä kirjanpainajatuhoja, jos kuollutta ja vaurioitunutta puuta jää sinne tänne metsään. Kirjanpainajien feromoniseurantaa on toteutettu Suomen Metsäkeskuksen ja Metlan/ Luonnonvarakeskuksen yhteistyönä vuodesta 2012 alkaen. Heinon \& Poutun (2013) raportista selviää, että kirjanpainajakannat ylittivät epidemiarajan vuonna 2010 sattuneen Asta-rajuilman ja joidenkin pienempien myrskyjen tuhoalueilla vielä monta vuotta myrskyjen jälkeen.

Tuulituhojen ennaltaehkäisyyn voidaan vaikuttaa suunnittelemalla metsien hakkuut siten, että puiden kaatumisriski jää mahdollisimman pieneksi. Säätyö-hankkeessa kehitetiin työkalua tähän tarkoitukseen. Toinen tuulituhoihin Säätyö-hankkeessa kehitetty tuote on myrskyn jälkeinen tilanneanalyysi. Laajoja metsätuhoja aiheuttavan myrskyn jälkeen on tärkeää luoda nopeasti mahdollisimman luotettava tilannekuva siitä, millä alueilla myrskytuhoja on tullut. Tällaisen analyysin pohjalta jatkotoimenpiteet voidaan kohdistaa ja mitoittaa mahdollisimman tehokkaasti. Esimerkiksi voidaan siirtää riittävästi puun korjuukalustoa tuhoalueelle tai muuttaa hakkuusuunnitelmaa muualla, jos tuhoalueelta tulee runsaasti tiettyä puutavaralajia. Metsänomistajia voidaan tiedottaa myrskyn jälkeen mahdollisesti syntyneestä tuhosta kohdistetusti pahimmalle tuhoalueelle ja kehottaa tarkistamaan tilanne omissa metsissään.

\subsubsection{Tuulituhoriskityökalusta kehitettiin testiversio}

Hankkeessa kehitetyllä tuulituhoriskityökalulla (testiversio) voidaan laskea puuston tuulituhoon (puiden kaatuminen) tarvittavia tuulennopeuksia metsäalueella. Riskiin vaikuttaa puulajin lisäksi puuston koko ja sijainti suhteessa tuulelle alttiiseen metsän reunaan (Gopalakrishnan ym., 2020). Tuulituhon syntyyn tarvittavia tuulennopeuksia voidaan 
tarkastella mikrokuvioilla $(16 \mathrm{~m} \times 16 \mathrm{~m})$ eri ilmansuunnista ennen ja jälkeen uuden avohakkuualan tai -alojen teon. Työkalulla voidaan myös havainnollistaa näiden tuulennopeuksien todennäköisyyttä eri ilmansuunnista ja arvioida puuston tuulituhoriskiä eri myrskytapausten tuulennopeuksilla. Sovelluksen testiversio ohjelmoitiin alun perin ArcMapohjelmistoympäristössä, jonka käyttö vaatii lisenssin hankkimista. Tämän vuoksi työkalun nykyinen versio on toteutettu QGIS-alustalla, sillä QGIS on avoimeen lähdekoodiin perustuva vapaa paikkatieto-ohjelmisto ilman lisenssimaksuja (GNU General Public License). Työkalu on kehitetty Itä-Suomen yliopiston Metsätieteiden osastolla Ilmatieteen laitoksen kanssa yhteistyössä. Se soveltuu tällä hetkellä vain tutkijakäyttöön.

Tuulituhoriskityökalulla voidaan analysoida puuston tuulituhoriskiä metsäalueelle satunnaisesti sijoitetuissa pisteissä, joiden puustotunnuksia käytetään puiden kaatumiseen tarvittavan tuulennopeuden laskennassa. Puiden kaatumiseen tarvittavaan tuulennopeuteen vaikuttavat sekä puuston ominaisuudet että sen sijaintiolosuhteet. Vaikuttavia ominaisuuksia ovat puulaji sekä puuston pituus ja solakkuus (pituuden ja rinnankorkeusläpimitan suhde). Näiden lisäksi on olennaista se, millä etäisyydellä puusto sijaitsee avohakkuun tai muun avoimen alan laidasta ja tarjoaako naapuripuusto sille tuulensuojaa. (Peltola ym., 1999; Heinonen ym. 2009). Laskennassa hyödynnetään laserkeilausaineistoihin pohjautuvia puustotietoja (mikrokuviot $16 \mathrm{~m} \times 16 \mathrm{~m}$, puuston valtapituus ja solakkuus). Tuulituhoon tarvittavien tuulennopeuksien todennäköisyyksien laskennassa hyödynnetään Ilmatieteen laitoksen tuottamaa alueellista tuulikenttää (tuulikertoimet), johon vaikuttaa sekä alueen topografia että pinnan rosoisuus. Rosoisuuteen puolestaan vaikuttaa, kuinka paljon tarkasteltavalla alueella on metsää, peltoa, vettä tai rakennettua aluetta (Venäläinen ym., 2017). Tässä tutkimuksessa käytetyt tuulennopeuksien todennäköisyydet ovat myös Ilmatieteen laitoksen eri sääasemille laskemia todennäköisyyksiä (ks. Peltola ym. 2010). Kuvassa 4.7 on esitetty noin 30 hehtaarin esimerkkialueella satunnaisesti valituilla pisteille tuulituhoriskin suuruus, olettaen $17 \mathrm{~m} \mathrm{~s}^{-1}$ puhaltava 10 minuutin keskituuli läheisellä sääasemalla.

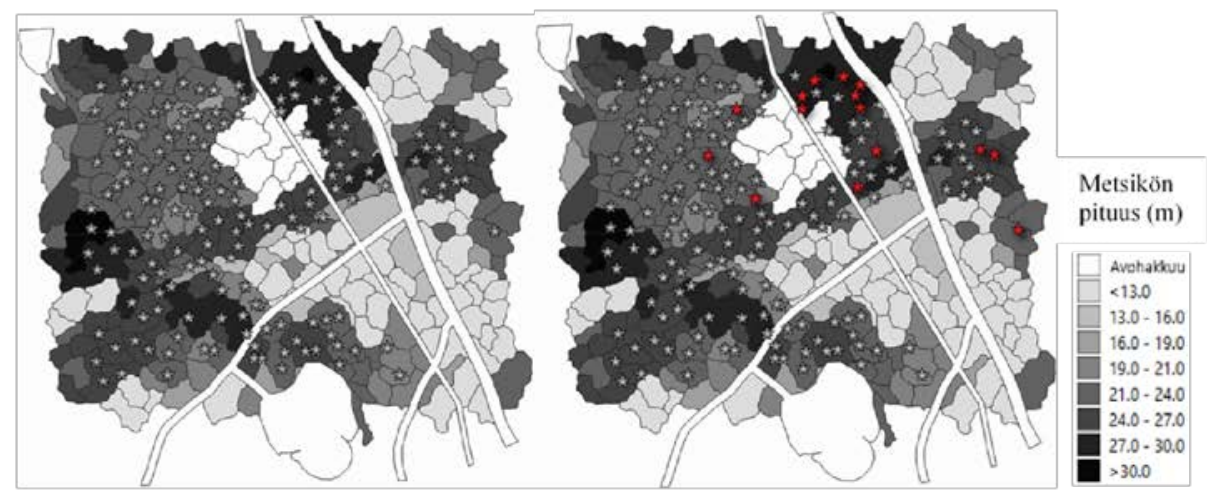

Kuva 4.7. Tuulituhoriski esimerkkialueella: harmaat puut eivät kaadu, punaiset puut kaatuvat. Laskennassa on otettu huomioon kahdeksan ilmansuuntaa (pää- ja sivuilmansuunnat), olettaen läheisellä säähavaintoasemalla 10 minuutin keskituulennopeudeksi $17 \mathrm{~m} \mathrm{~s}^{-1}$. Valkoisille kuvioille on tehty avohakkuu. Laskennassa on käytetty sekä mikrokuvioiden keskipuiden läpimittoja (vasemmalla) että $10 \%$ pienempiä puuston läpimittoja (oikealla), millä havainnollistetaan saatujen tulosten herkkyyttä käytetyille puustotiedoille. 


\subsubsection{Hankkeessa testattiin myrskyn jälkeisten mahdollisten tuulituhoalueiden kartoittamista}

Laajoja metsätuhoja aiheuttavan myrskyn jälkeen on tärkeää luoda nopeasti mahdollisimman luotettava tilannekuva siitä, millä alueilla myrskytuhoja on tapahtunut. Tällaisen analyysin pohjalta jatkotoimenpiteet voidaan kohdistaa ja mitoittaa mahdollisimman tehokkaasti. Myös sähköyhtiöt tarvitsevat tietoa raivaus- ja linjankorjaustyöhönsä. Laajemman myrskytuhon (tuulituhon) sattuessa sähköyhtiöt pyytävät yleensä apua metsäkoneyrittäjiltä, sillä omat resurssit eivät useinkaan riitä. Pelastuslaitos tarvitsee tiedon esimerkiksi tielinjojen avaamiseksi. Metsäpuolella on tärkeä tietää myrskytuhojen määrä ja sijainti, koska silloin voidaan kohdistaa esimerkiksi metsäkonekantaa tietylle alueelle. Tuhot pistävätkin usein joltain alueelta puuta ostavien yritysten korjuujärjestyksen uusiksi.

Säätyö-hankkeessa testattiin mahdollisuutta paikantaa pahimmat tuulituhoalueet välittömästi tapahtuneen myrskyn jälkeen. Lähestymistapana oli sääasemilla tehtävien tuulihavaintojen alueellistaminen "kriging”-nimisellä alueellisella interpolointimenetelmällä. Havaintoihin perustuva lähestymistapa tarjoaa mahdollisuuden nopeaan analyysiin verrattuna esimerkiksi nk. uusanalyyseihin, joiden tuotantoon liittyy vähintään useamman vuorokauden viive. Käytettävä menetelmä, kriging, on perustaltaan sama, mitä käytetään myös muiden säätietojen alueellisessa interpoloinnissa (Aalto ym., 2016). Myrskyn aikana havaittujen tuulen maksimipuuskien interpolointia varten menetelmää on jatkokehitetty parantamalla alueellista erotuskykyä 1000 metristä 500 metriin. Tyypillisesti interpoloitavan suureen alueellista vaihtelua selittävinä muuttujina käytetään maaston korkeutta sekä alueen merellisyyttä ja järvisyyttä. Tässä tuulen interpoloinnissa uutena selittävänä muuttujana käytettiin maanpinnan rosoisuutta. Rosoisuus riippuu kasvillisuudesta (peltoa, metsää, tundraa ym.) ja myös siitä, millaisia rakennuksia alueella on (Laapas ym., 2021).

Säähavaintojen tekoon käytettävät sääasemat sijaitsevat tyypillisesti suhteellisen avoimilla alueilla, joissa tuulianturit sijaitsevat yleensä 10 metrin korkeudessa. Näin ollen sääasemaverkostolla havaitut tuulimaksimit ovat yleisesti voimakkaampia kuin todelliset tuulen nopeudet metsissä. Tämä voidaan ottaa paremmin huomioon nyt käytetyllä menetelmällä, missä korkeamman rosoisuuden alueilla, kuten metsissä, interpoloidut tuulen voimakkuudet ovat rosoisuustietoa käytettäessä realistisempia.

Esimerkkinä havaittujen maksimipuuskien interpoloinnista on Päivö-myrsky (Kuva 4.8), joka liikkui Päivön päivänä 30. kesäkuuta 2020 Itä-Suomen yli pohjoiseen. Myrsky aiheutti paljon tuulituhoja Etelä-Karjalasta Kainuuseen. Se kaatoi metsää noin 400000 kuutiometriä, ja katkaisi sähköt noin 100000 taloudelta. Tuulen nopeus oli puuskissa laajalti yli $20 \mathrm{~m} / \mathrm{s}$ ja jopa yli $25 \mathrm{~m} / \mathrm{s}$ myrskyn pahiten runtelemilla alueilla Pohjois-Savossa ja Pohjois-Karjalassa (Ilmastokatsaus 6/2020). 


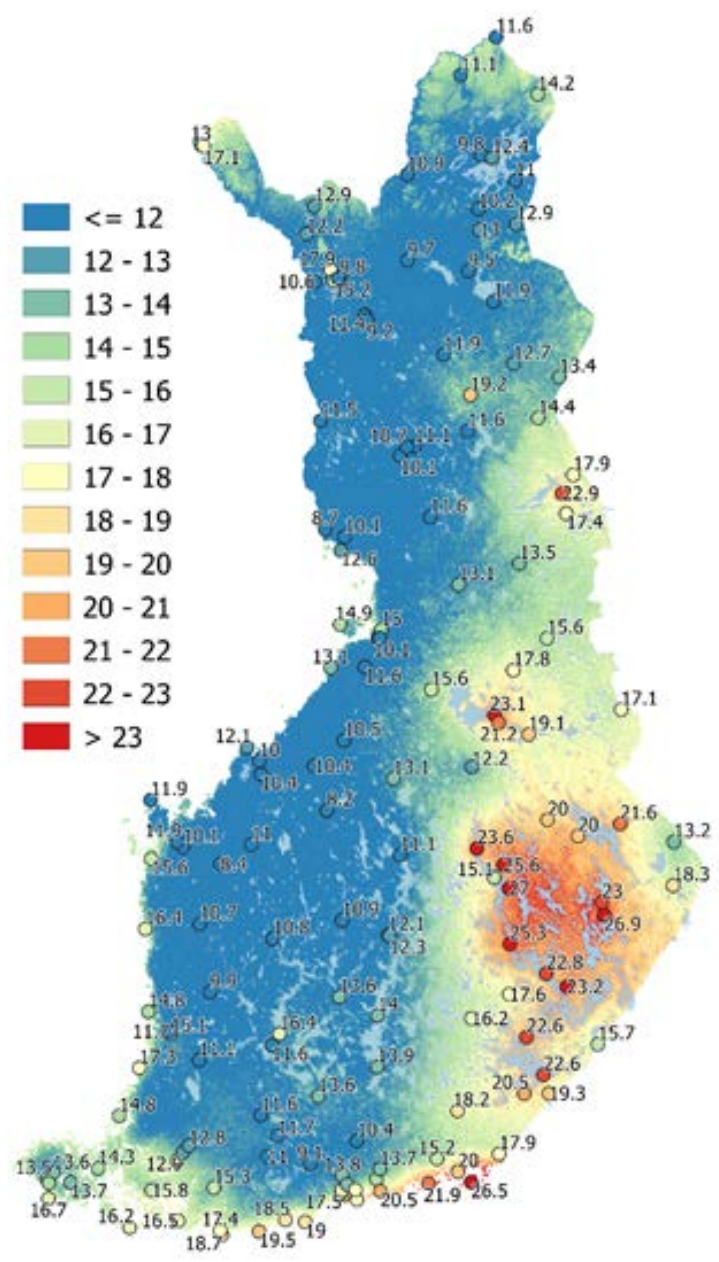

Kuva 4.8. Päivö-myrskyn (30.6.2020) aikana säähavaintoasemilla mitatut suurimmat tuulen puuskanopeudet interpoloituna $500 \mathrm{~m} \times 500 \mathrm{~m}$ hilaruudukkoon. Kartalla punaiset sävyt kuvaavat suurimpia, yli 20 m/s:n tuulennopeuksia, joita mitattiin Itä-Suomessa.

Tuulituhojen kannalta oleellista on myös tieto metsien haavoittuvuudesta tuulituhoille. Kun yhdistetään nämä kaksi tietoa, eli myrskyn aikaisten maksimipuuskien alueellinen jakauma sekä tieto metsien herkkyydestä tuulituhoille, voidaan päästä parempiin tuloksiin myrskyn jälkeisten potentiaalisten tuulituhoalueiden kartoittamisessa. Tämä havaittiin analysoimalla interpoloitujen puuskamaksimien, Luken tuottaman tuulituhoriskiaineiston (Suvanto ym., 2019) ja edellisten yhdistelmän osumatarkkuutta tuulituhoalueiden (metsänkäyttöilmoitukset, myrskytuhohakkuut) kanssa yhdeksän 2010-luvulla tuhoja aiheuttaneen myrskyn (Valta ym., 2019) tapauksessa.

\section{Metsäbiotalouden toimijat tarvitsevat helposti arjessa käytettäviä tietotuotteita}

- Metsäbiotalouden sidosryhmien mielestä uusille sää- ja ilmastotietotuotteille on käyttöä.

- Sidosryhmien mukaan etenkin lumi- ja tuulituhoriskiä sekä maan korjuukelpoisuutta koskevia tietotuotteita olisi mahdollista kehittää kohti kaupallistamista.

- Sidosryhmien näkemyksiä uusista tietotuotteista selvitettiin haastatteluissa ja työpajassa. 


\subsection{Tietotuotteiden tulee tarjota käyttäjille ratkaisuja päätöksentekoon}

Digitalisaation mahdollistama tietoon ja mallintamiseen pohjautuva liiketoiminta kasvattaa merkitystään myös perinteisillä toimialoilla, kuten metsäsektorilla. Tämän on ottanut huomioon myös päivitetty kansallinen metsästrategia, joka tunnistaa digitalisaation hyödyntämisen olevan avainasemassa metsäsektorin uudistamisessa ja sen kestävyyden turvaamisessa (MMM, 2019).

Metsäbiotalous voi varautua ja sopeutua muuttuvaan ilmastoon hyödyntämällä tehokkaasti saatavilla olevaa avointa tietoa ja ennusteita sääolosuhteista ja niiden vaikutuksista sektorin eri toimintoihin. Laadukkaan tiedon ja ennusteiden tuottaminen on ensiarvoisen tärkeää, mutta merkittävässä roolissa on myös niiden tuominen käytäntöön. Metsäbiotalouden toimijat tarvitsevat tietoa ja ennusteita hyödyntäviä tietotuotteita ja -palveluita, joita voidaan luontevasti ja helposti käyttää osana arkipäiväistä työntekoa. Tällöin tieteellinen tieto muuntuu sujuvasti osaksi metsäsektorin käytäntöjä, muokaten niistä entistä ilmastokestävämpiä. Näin voidaan tuottaa hyötyä, joka konkretisoituu esimerkiksi metsänomistajan suurempana taloudellisina tulona, luontoarvojen parempana huomioimisena tai metsäteollisuuden tehokkaampana puuhuoltona.

Tietoon pohjautuvien tuotteiden ja palveluiden kaupallistaminen edellyttää, että niistä saatava lisäarvo on suurempi kuin niihin liittyvä kustannus. Tietotuotteen tulee tarjota ratkaisukeinoja sellaiseen toiminnan kannalta merkittävään ongelmaan, johon on mahdollista vaikuttaa omilla päätöksillä. Lisäksi tuotteen helppokäyttöisyys korostuu tuotteen käyttöönotossa. Siksi palvelumuotoilu eli käyttäjälähtöinen tuote- ja palvelukehitys nähdään olennaisena osana prosessia.

\subsection{Aineistona ja menetelmänä käytettiin sidosryhmähaastatteluja ja työpajatyöskentelyä}

Säätyö-hankkeessa kartoitettiin haastatteluissa ja työpajassa tietotuotteiden käyttökohteita, hyötyjä, käyttöönoton edellytyksiä ja kehitysmahdollisuuksia. Hankkeessa haastateltiin 21 organisaation edustajia sovelletun puolistrukturoidun haastattelurungon avulla. Tämä tarkoittaa, että haastatteluissa käsiteltävät aihepiirit ja kysymykset olivat ennalta määriteltyjä, mutta ne käytiin läpi joustavasti esimerkiksi haastateltavan osaaminen ja näkemykset huomioiden. Kysymysrunko ja tiiviit kuvaukset hankkeessa kehitettävistä tietotuotteista laadittiin yhteistyössä niistä vastaavien tutkijoiden kanssa. Näin varmistettiin, että haastateltavat saivat mahdollisimman todenmukaisen ja ajantasaisen kuvauksen tietotuotteista, niiden yksityiskohdista sekä senhetkisistä kehitysvaiheista.

Haastattelujen tarkoituksena oli 1) arvioida näiden neljän tietotuotteen tuomaa lisäarvoa metsäsektorille ja 2) kartoittaa niiden käyttöä ja jatkokehitysmahdollisuuksia eli sitä, millaista kaupallista potentiaalia tietotuotteilla arveltiin olevan. Haastattelut, jotka nauhoitettiin, toteutettiin touko-heinäkuussa 2019. Suurin osa niistä toteutettiin kasvotusten, loput puhelimitse.

Haastatteluilla kerättyä aineistoa analysoitiin syksyn 2019 aikana ja täydennettiin lokakuussa 2019 järjestetyssä työpajassa ${ }^{1}$. Työpajaan osallistui 15 metsäbiotalouden toimijaa, jotka edustivat mm. metsänomistajia, sahateollisuutta, IT-alaa sekä tutkimuslaitoksia. Työpajan

\footnotetext{
1 Työpaja järjestettiin 22.10.2019 klo 12.30-15.30, kokouspaikkana maa- ja metsätalousministeriön kokouskeskus (Mariankatu 9).
} 
sisältö oli kaksivaiheinen: aluksi esiteltiin haastatteluiden tuloksia eli tietotuotteiden käyttökohteita, saavutettavissa olevia hyötyjä, käyttäjäryhmiä, käytön vaatimuksia sekä niiden jatkokehitysehdotuksia. Tämän jälkeen jakauduttiin kahteen ryhmään, joissa käsiteltiin valittuja tietotuotteita palvelumuotoiluun ja yhteiskehittämiseen kehitetyn CoCo Toolkit -työkalun avulla ${ }^{2}$. Tavoite oli testata tietotuotteille haastatteluissa nähtyjä käyttökohteita ja hyötyjä sekä tunnistaa keskeisiä jatkokehityspolkuja ja ongelmakohtia tuotteistamisen ja käyttöönoton mahdollistamiseksi.

Tietotuotteiden kaupallistamisen tueksi tehtiin kirjallisuuskatsaus, joka käsittelee markkinoilla syntyneitä datan jakamiseen ja hinnoitteluun soveltuvia malleja. Niiden soveltuvuutta hankkeessa kehitettyihin tietotuotteisiin oli mahdollista arvioida vain rajoitetusti, sillä haastattelujen perusteella tietotuotteista ei niiden nykymuodossa oltu halukkaita maksamaan.

\subsection{Haastattelujen ja työpajan tulosten mukaan tietotuotteet ja -palvelut ovat hyödyllisiä ja tarpeellisia}

\subsubsection{Haastateltavien mielestä uusia tietotuotteita voi käyttää monipuolisesti}

Haastatteluissa Säätyö-hankkeessa kehitetyille uusille tietotuotteille tuli esille monipuolisia käyttömahdollisuuksia. Tyypillisesti kussakin haastattelussa keskityttiin yhteen tai kahteen tietotuotteeseen, jonka käyttökohteista, hyödyistä, käyttäjistä ja käytön edellytyksistä keskusteltiin. Haastattelujen lopuksi haastateltaville tarjottiin mahdollisuus kommentoida lyhyesti myös muiden tietotuotteiden käytettävyyttä ja hyötyjä.

\section{Lumi- ja tuulituhoriskejä koskevia tietotuotteita voidaan hyödyntää metsänhoidon suunnittelussa}

Lumi- ja tuulituhoriskejä koskevien tietotuotteiden käyttömahdollisuuksia pidettiin samankaltaisina ja niiden käyttökohteet on siksi esitelty yhdessä (taulukko 5.1).

Haastateltavien mielestä lumi- ja tuulituhoriskiä koskevien tietotuotteiden avulla voidaan edistää ennen kaikkea sääolojen muutokset huomioivaa metsänhoitoa. Siten voidaan pienentää niistä johtuvien metsätuhojen ja taloudellisten menetysten todennäköisyyttä.

Käytännössä tietoa tuulituhoriskin vaihtelusta voidaan hyödyntää esimerkiksi uudistushakkuiden suunnittelussa ja rajauksessa. Tieto metsikön lumituhoriskistä kannattaa ottaa huomioon etenkin mäntyvaltaisten metsiköiden harvennuksien ja lannoitusten suunnittelussa. Molemmissa tiedon käyttötavoissa tavoitteena on pyrkiä minimoimaan jäljelle jäävään puustoon kohdistuvat tuhot.

Pääasiallisina tiedon käyttäjinä nähtiin metsänomistajat (etenkin ammattimaisesti metsiin sijoittavat) sekä heitä metsien hoidossa ja käytössä ohjaavat tahot. Jälkimmäisiä ovat esimerkiksi metsäneuvojat ja leimikkosuunnittelijat.

Haastatteluissa korostettiin, että riskitietoa voidaan hyödyntää myös lumen tai tuulen vahingoittaman puuston korjuussa. Lumi- ja tuulituhoriskitiedon avulla metsänomistajien tai heidän valtuuttamiensa toimijoiden on mahdollista paikantaa tuhoja tehokkaammin silloin, kun tiedetään, että olosuhteet tuhojen syntymiselle ovat olleet otolliset. Korjaamalla vahingoittunut

\footnotetext{
${ }^{2}$ Lisätietoa Cambridgen yliopiston ja Laurea ammattikorkeakoulun kehittämästä CoCo Toolkit -työkalusta: https://www.laurea.fi/cocotoolkit/
} 
puu nopeasti tuhon tapahtumisen jälkeen voidaan pienentää taloudellisia menetyksiä sekä viiveellä seuraavia hyönteistuhoja

Taulukko 5.1. Lumi- ja tuulituhoriskejä koskevat tietotuotteet.

\begin{tabular}{|c|c|}
\hline Käyttökohteet ja hyödyt & Käyttäjät \\
\hline $\begin{array}{l}\text { Metsänhoito } \\
\text { Metsänhoidon, etenkin uudistushakkuiden, } \\
\text { harvennuksien, lannoitusten suunnittelu ja rajaus sekä } \\
\text { puulajivalinta metsänuudistamisessa } \\
>\text { Vähemmän tuhoja ja taloudellisia menetyksiä } \\
\text { Yhteydenottojen ja koulutusten kohdentaminen } \\
\quad \text { Tietoisuuden lisääminen riskeistä ja niiden } \\
\quad \text { huomioimisesta }\end{array}$ & $\begin{array}{l}\text { Metsänomistajat, } \\
\text { metsäsijoittajat, } \\
\text { metsäneuvojat, Suomen } \\
\text { metsäkeskus, } \\
\text { metsäpalveluyrittäjät }\end{array}$ \\
\hline $\begin{array}{l}\text { Hakkuu ja korjuu } \\
\text { Tuhojen tehokkaampi paikantaminen } \\
\quad>\text { Resurssien kohdentaminen, taloudellisten } \\
\text { menetysten ja hyönteistuhojen minimointi } \\
\quad>\text { Työturvallisuuden parantaminen } \\
\text { Yhteydenottojen kohdentaminen } \\
>\text { Metsänomistajien aktiivisuuden lisääminen } \\
\text { Sähkölinjojen vierusmetsien kunnossapito } \\
\quad>\text { Resurssien kohdentaminen, sähkökatkojen ja } \\
\quad \text { vahingonkorvausten minimointi }\end{array}$ & $\begin{array}{l}\text { Leimikkosuunnittelijat, } \\
\text { metsänomistajat, } \\
\text { metsänhoitoyhdistykset, } \\
\text { metsäpalveluyritykset, } \\
\text { sähköyhtiöt, vierusmetsiä } \\
\text { hoitavat yrittäjät }\end{array}$ \\
\hline $\begin{array}{l}\text { Kuljetus ja varastointi } \\
\text { Tieverkoston kunnossapito } \\
\quad>\text { Resurssien kohdentaminen, vahinkojen } \\
\quad \text { minimointi }\end{array}$ & $\begin{array}{l}\text { Hoitokunnat, } \\
\text { liikennevirasto }\end{array}$ \\
\hline $\begin{array}{l}\text { Metsävakuutukset } \\
\text { Metsävakuutusten ja niiden hinnoittelun kehittäminen } \\
>\text { Ymmärrys vakuutustarpeesta, riskiä } \\
\text { heijasteleva hinnoittelu }\end{array}$ & $\begin{array}{l}\text { Metsänomistajat, } \\
\text { vakuutusyhtiöt }\end{array}$ \\
\hline $\begin{array}{l}\text { Alueellinen suunnittelu } \\
\text { Riskit tulisi huomioida alueellisessa strategisessa } \\
\text { suunnittelussa ja riskienhallinnassa } \\
\quad>\text { Vahvempi alueellinen sopeutuminen } \\
\text { Yleinen huoltovarmuus } \\
\quad>\text { Kalustoa voisi siirtää ennakoivasti }\end{array}$ & $\begin{array}{l}\text { Pelastuslaitos, kunnat, } \\
\text { maa- ja } \\
\text { metsätalousministeriö, } \\
\text { alueelliset } \\
\text { metsäneuvostot }\end{array}$ \\
\hline
\end{tabular}


Haastateltavat kokivat, että tietoa lumi- ja tuulituhoriskistä kannattaisi hyödyntää metsänomistajille tehtävässä neuvonnassa. Jakamalla riskitietoa aktiivisesti ja kohdennetusti entistä useampi metsänomistaja voisi päästä kiinni tiedon käyttämisestä syntyviin hyötyihin.

Lumi- ja tuulituhoriskiin liittyvän tiedon nähtiin tuovan lisäarvoa myös sähkölinjojen vierusmetsien hoitoon. Sähköyhtiöt sekä vierusmetsiä hoitavat yrittäjät voivat hyödyntää riskitietoa silloin, kun he arvioivat hoitokohteiden kiireellisyyttä. Hoitamalla ensisijaisesti niitä vierusmetsiä, joiden lumi- tai tuulituhoriski on korkea, voidaan mahdollisesti pienentää sähkökatkojen ja niihin liittyvien vahingonkorvausten todennäköisyyttä.

Lumi- ja tuulituhoriskiä käsittelevälle tiedolle mainittiin yksittäisissä haastatteluissa myös muita mahdollisia käyttökohteita. Esiin tuotiin esimerkiksi se, että (metsä)tieverkoston kunnossapidon resursseja voisi ennakoivasti kohdentaa niille alueille, joilla riskitaso on koholla. Näin kohennettaisiin huoltovarmuutta sekä tuhopuun tehokkaampaa korjuuta. Riskiaineistojen nähtiin tuovan hyötyä myös strategiseen suunnitteluun sekä ilmastonmuutokseen liittyvään riskienhallintaan alueellisella tasolla.

Lumi- ja tuulituhoriskiä koskevien tietotuotteiden käytölle esitettiin haastatteluissa erilaisia edellytyksiä ja toiveita. Lähes kaikki haastateltavat kokivat, että riskitiedon tulisi olla saatavilla ilmaiseksi. Riskitiedon käyttöönottoa edistäisi se, että tieto olisi saatavilla jo käytössä olevan järjestelmän kautta, esimerkiksi karttatasona Metsään.fi-verkkosivustolla tai rajapintojen kautta erillisessä metsävaratietojärjestelmässä. Myös alueellisessa suunnittelussa ja huoltovarmuuden edistämisessä tuuli- ja lumituhotiedon käyttöä lisäisi se, että ilmastonmuutokseen liittyviä riskiaineistoja olisi saatavilla keskitetysti yhdestä paikasta ${ }^{3}$. Haastatteluissa nostettiin esille tiedon ajantasaisuus: koska tuhoriskiin vaikuttavat metsikössä tai naapurikuvioilla tehdyt toimenpiteet, tulisi riskitiedon ottaa nämä huomioon. Myös tiedon käytettävyyttä maastossa eli mobiilikäyttömahdollisuutta toivottiin.

\section{Maan kosteustietoa ja sulan maan korjuuolosuhteita kuvaavaa ennustetta voidaan hyödyntää hakkuissa ja puunkorjuussa}

Haastateltavat suhtautuivat hyvin positiivisesti ajantasaiseen tietoon maan kosteudesta ja sulan maan korjuuolosuhteista. Myös maan kosteutta ja korjuuolosuhteita koskeva ennuste nähtiin hyvin käyttökelpoisena. Tiedon potentiaalisia käyttökohteita ja käyttäjäryhmiä on esitelty taulukossa 5.2.

Tieto ja ennen kaikkea ennuste sulan maan kantavuudesta/korjuuolosuhteista nähtiin tuovan merkittäviä hyötyjä hakkuiden ja puun korjuun suunnitteluun ja toteutukseen. Esimerkiksi 1-2 viikon kantavuusennusteen avulla korjuuyrittäjien ja korjuusta vastaavien työntekijöiden olisi mahdollista tarkentaa käsitystä leimikoiden toteutuskelpoisuudesta ja lyhyen aikavälin puun saatavuudesta. Ajantasaisempi tieto leimikoiden korjuuolosuhteista auttaa vähentämään työhön liittyvää kausivaihtelua ja nostamaan kaluston käyttöastetta. Kantavuustiedon avulla voidaan kuljettajille tehdä myös tarkempia ehdotuksia leimikolle sopivista ajourista, mikä vähentää korjuuvaurioita. Leimikon kantavuuden lisäksi tieverkoston kantavuus on merkittävä puun saatavuuteen vaikuttava tekijä, siksi maan kosteustietoa ja -ennustetta tulisi hyödyntää myös kuljetusten ja varastoinnin suunnittelussa. Tutkimushankkeet, joissa hyödynnetään maan kosteustietoa sekä tarkempaan leimikon ajourasuunnitteluun että tiestön kuljetuskelpoisuuteen, ovatkin Metsätehossa jo käynnissä.

\footnotetext{
${ }^{3}$ Esimerkkinä mainittiin https://www.ilmasto-opas.fi
} 
Taulukko 5.2. Maan kosteutta ja sulan maan kantavuutta koskevat tietotuotteet.

\begin{tabular}{|c|c|}
\hline Käyttökohteet ja hyödyt & Käyttäjät \\
\hline $\begin{array}{l}\text { Puukauppa ja metsänhoito } \\
\text { Leimikoiden osto ja suunnittelu } \\
\quad>\text { Vähemmän maastotyötä ja parempi käsitys } \\
\quad \text { puun saatavuudesta } \\
\quad>\text { Mahdollisuus pienentää varastoja } \\
\text { Maanmuokkauksen ja istutuksen/viljelyn ajoitus } \\
\quad>\text { Metsänuudistamisen parempi onnistuminen }\end{array}$ & $\begin{array}{l}\text { Leimikkosuunnittelijat, } \\
\text { puun ostajat, } \\
\text { metsäpalveluyrittäjät, } \\
\text { metsänomistajat }\end{array}$ \\
\hline $\begin{array}{l}\text { Hakkuu ja korjuu } \\
\text { Lyhyen aikavälin suunnittelu } \\
\quad>\text { Parempi käsitys leimikoiden } \\
\text { toteutusjärjestyksestä } \\
>\text { Kausivaihtelun vähentäminen, käyttöasteen } \\
\text { nosto } \\
>\text { Vähemmän kaluston turhaa siirtelyä ja jumiin } \\
\text { jäämistä } \\
\text { Hakkuiden toteutus } \\
>\text { Parempi ajourien suunnittelu, vähemmän } \\
\quad \text { maasto- ja puustovaurioita } \\
\text { Hakkuutähteen keruun ajoitus } \\
>\text { Hakkuutähteen keruu kuivempana } \\
\text { Metsäpaloriskin tarkentaminen ja ennustaminen } \\
>\text { Hakkuista syntyvien metsäpalojen ehkäisy }\end{array}$ & $\begin{array}{l}\text { Korjuuyrittäjät, } \\
\text { kuljettajat, } \\
\text { operaatioesimiehet, } \\
\text { energiapuun korjuusta } \\
\text { vastaavat }\end{array}$ \\
\hline $\begin{array}{l}\text { Kuljetus ja varastointi } \\
\text { Kuljetuskelpoisuus } \\
\quad>\text { Puun saatavuus, vahinkojen minimointi, } \\
\text { resurssien kohdennus }\end{array}$ & $\begin{array}{l}\text { Logistiikkasuunnittelijat, } \\
\text { kuljetusyrittäjät, } \\
\text { kuljettajat }\end{array}$ \\
\hline $\begin{array}{l}\text { Luontomatkailu } \\
\text { Matkailupalvelut } \\
\quad \text { > Paremmat reittien valinnat }\end{array}$ & $\begin{array}{l}\text { Virkistyskäyttäjät, } \\
\text { luontomatkailuyrittäjät }\end{array}$ \\
\hline
\end{tabular}

Puukauppatilanteessa kantavuustiedon uskottiin vähentävän puun ostajien maastotyön tarvetta ja säästävän siten kaupantekoon liittyviä kustannuksia. Lisäksi haastatteluissa mainittiin mahdollisina maan kosteustiedon käyttökohteina hakkuutähteen korjuun ajoittaminen ja hakkuisiin liittyvän metsäpaloriskin tarkentaminen.

Maan kosteustieto ja sen ennuste nähtiin yksittäisissä haastatteluissa hyödyllisenä myös metsänhoidollisten töiden, kuten maanmuokkauksen ja metsänuudistamisen ajoittamisessa sekä luontomatkailuyrittäjien reittivalintojen suunnittelussa.

Maan kosteutta ja sulan maan kantavuutta koskevien tietotuotteiden käytölle esitettiin haastatteluissa erilaisia edellytyksiä ja toiveita. Korjuukelpoisuustiedon koettiin tuovan hyötyä etenkin silloin, kun olosuhteet muuttuvat nopeasti, kuten kelirikkoaikaan. Siksi tärkeänä 
edellytyksenä tiedon käytölle nähtiin kantavuustiedon ajantasaisuus ja, olosuhteiden niin vaatiessa, tiheä päivitys. Maan kosteutta ja kantavuutta koskeva kymmenen päivän ennustejakso nähtiin hyvin tarpeellisena, joskin myös pidempi kolmen kuukauden ennustejakso koettiin tietyissä tilanteissa käyttökelpoiseksi. Aineistolta vaadittavan alueellisen tarkkuuden resoluution kerrottiin vaihtelevan käyttötarkoituksen mukaan: leimikon ajourasuunnittelu vaatisi tarkempaa tietoa kuin alueellisen tason suunnittelu. Tiedon käyttöä edistäisi huomattavasti se, että se olisi saatavilla jo käytössä olevan järjestelmän kautta, esimerkiksi WoodForce-tietojärjestelmässä. Kantavuustiedon toivottiin olevan lähtökohtaisesti avoin, ilmainen aineisto, jonka päälle olisi mahdollista kehittää kaupallisia palveluja. Yleisesti ottaen haastateltavat kertoivat, että tietotuotteen helppokäyttöisyys ja luotettavuus ovat ominaisuuksia, jotka määrittäisivät tuotteen käyttöä testikäytöstä eteenpäin.

\section{Vaikutustietokannan avulla voidaan strategisesti ohjata metsäsektorin toimia ilmastonmuutokseen sopeutumiseksi}

Vaikutustietokantaa käsiteltiin haastatteluissa muihin tietotuotteisiin verrattuna melko vähän. Tähän vaikutti se, että haastatteluihin valikoitui ennen kaikkea metsätalouteen ja puuhuoltoketjuun kytköksissä olevia toimijoita. Yleisesti ottaen tietokanta nähtiin tärkeänä hallinnollisena ja strategisena välineenä metsäsektorin sopeutumistoimien ohjaamisessa.

Haastateltavien mielestä metsäsektorilla on selvä tarve kehittää määrällisiä ennusteita metsiin kohdistuvista ilmastoriskeistä ja mahdollisten vahinkojen laajuudesta. Ennakoivan työn tulisi perustua systemaattisesti kerättyihin tietoihin toteutuneista vahingoista, esimerkiksi satelliittikuvia hyödyntäen. Ennusteiden kautta olisi mahdollista tarkentaa käsitystä niistä ilmastonmuutokseen liittyvistä riskeistä, joihin metsäbiotaloudessa tulisi varautua. Tämän pohjalta voidaan suunnitella painopistealueita, niiden kiireellisyyttä, vaadittavia resursseja sekä käytännön toimenpiteitä.

Haastateltavat korostivat, että tietoa sääolosuhteiden aiheuttamista vahingoista sekä ennakoitavista riskeistä tulisi olla saatavilla sekä valtakunnallisella että alueellisella tasolla. Koska riskien todennäköisyys vaihtelee alueiden välillä, myös toimet ilmastonmuutokseen sopeutumiseksi tulisi suunnitella alueellisesti, esimerkiksi alueellisten metsäohjelmien kautta.

Vaikutustietokannan tulisi olla julkisen ja tunnetun organisaation, kuten Ilmatieteen laitoksen, hallinnoima. Sen kehityksessä erityishuomio tulisi olla helppokäyttöisyydessä, jotta toimijat eri hallinnon tasoilla voisivat ottaa sen luontevasti käyttöön sekä syöttääkseen että hakeakseen tietoja. Yhteisen tietokannan käytön nähtiin edistävän hallinnollisten tahojen käymää vuoropuhelua ja yhteistyötä.

\subsubsection{Palvelumuotoilu-työpaja vahvisti haastatteluiden tuloksia}

Palvelumuotoilua sovelletaan tänä päivänä moneen eri käyttökohteeseen. Palvelumuotoilu on käyttäjälähtöistä palvelujen innovointia, kehittämistä ja suunnittelua, jota toteutetaan usein yhdessä eri sidosryhmien kanssa (co-creation). Yhteissuunnittelun pohjana on palvelun sidosryhmien näkökulmien ja käyttäytymisen ymmärtäminen ja sen avulla palvelun laadun parantaminen sekä siihen liittyvien riskien pienentäminen.

Palvelumuotoilu-työpajassa hyödynnettiin CoCo Toolkit -työkalua, joka on palvelumuotoiluun ja yhteissuunnitteluun kehitetty peli. Siinä pelilaudalle jäsennellään toimintaa, sidosryhmiä ja tuloksia eriväristen pelikorttien avulla. Näitä elementtejä voidaan yhdistää toisiinsa viivoin, jotka kuvaavat yhteyksiä, esteitä ja tarpeita. Pelin tarkoitus on visuaalisin keinoin kuvata eri toimijoiden yhdessä rakentama palvelukokonaisuus ja tunnistaa siihen liittyviä haasteita ja kehitysmahdollisuuksia. 
Työpajassa jakauduttiin kahteen pienryhmään, joista ensimmäinen käsitteli lumi- ja tuulituhoriskiin ja toinen sulan maan korjuukantavuuteen liittyvää tietotuotetta.

Lumi- ja tuulituhoriskeihin keskittynyt pienryhmä vahvisti käsitystä haastatteluissa esiin nousseista pääasiallisista riskitiedon käyttökohteista (kuva 5.1). Tiedon käyttäjäkunta nähtiin laajana. Ryhmä nosti esiin etenkin tiedon hyödyntämisen metsänhoitoa koskevassa päätöksenteossa, jonka avulla voidaan edistää metsien sopeutumiskykyä sään ääri-ilmiöihin sekä pienentää tuhoista syntyviä taloudellisia vahinkoja. Ryhmässä keskusteltiin myös tiedon hyödyntämisestä tuhovaroitusten ja -arvioiden kehittämisessä, jotta tuhoihin voitaisiin sekä varautua ennalta että reagoida nopeasti niiden syntymisen jälkeen.

Operatiivisen tason toimenpiteiden sopeuttamisen lisäksi ryhmä painotti, että lumi- ja tuulituhoriskitietoa sekä vastaavia aineistoja tulisi hyödyntää entistä tehokkaammin strategisessa suunnittelussa. Sekä metsäsektorin hallinnon että liiketoiminnan tulisi tarkentaa käsitystään ilmastonmuutoksen tuomista metsiin kohdistuvista riskeistä, arvioida niihin liittyviä (etenkin taloudellisia ja hiilensidontaan kohdistuvia) vaikutuksia sekä ohjata resursseja sopeutumista tukevaan tutkimus- ja kehittämistoimintaan. Tämä edellyttäisi laadukasta, ajantasaista tutkimustietoa sekä sen tehokasta hyödyntämistä muun muassa tietokantakehityksen ja viestinnän keinoin.

Kuten haastatteluissakin, sulan maan korjuukantavuutta koskevassa ryhmässä nostettiin esiin kantavuustiedon ja -ennusteen monipuolinen hyödyntäminen etenkin puunhankintaketjun eri tehtävissä (kuva 5.2). Säätietojen yhdistäminen staattiseen korjuukelpoisuuskarttaan hyödyntäisi erityisesti korjuun suunnittelua ja teiden kunnon arviointia. Paremman kantavuustiedon avulla voidaan saavuttaa kustannussäästöjä metsänomistajille, korjuuyrittäjille ja puunostajille: vähemmän korjuuvaurioita metsässä ja teillä, toimivampia reittejä virkistyskäyttäjille ja luontomatkailuun, sekä yleisesti ottaen parempaa hyväksyttävyyttä metsäalan operatiiviselle toiminnalle.

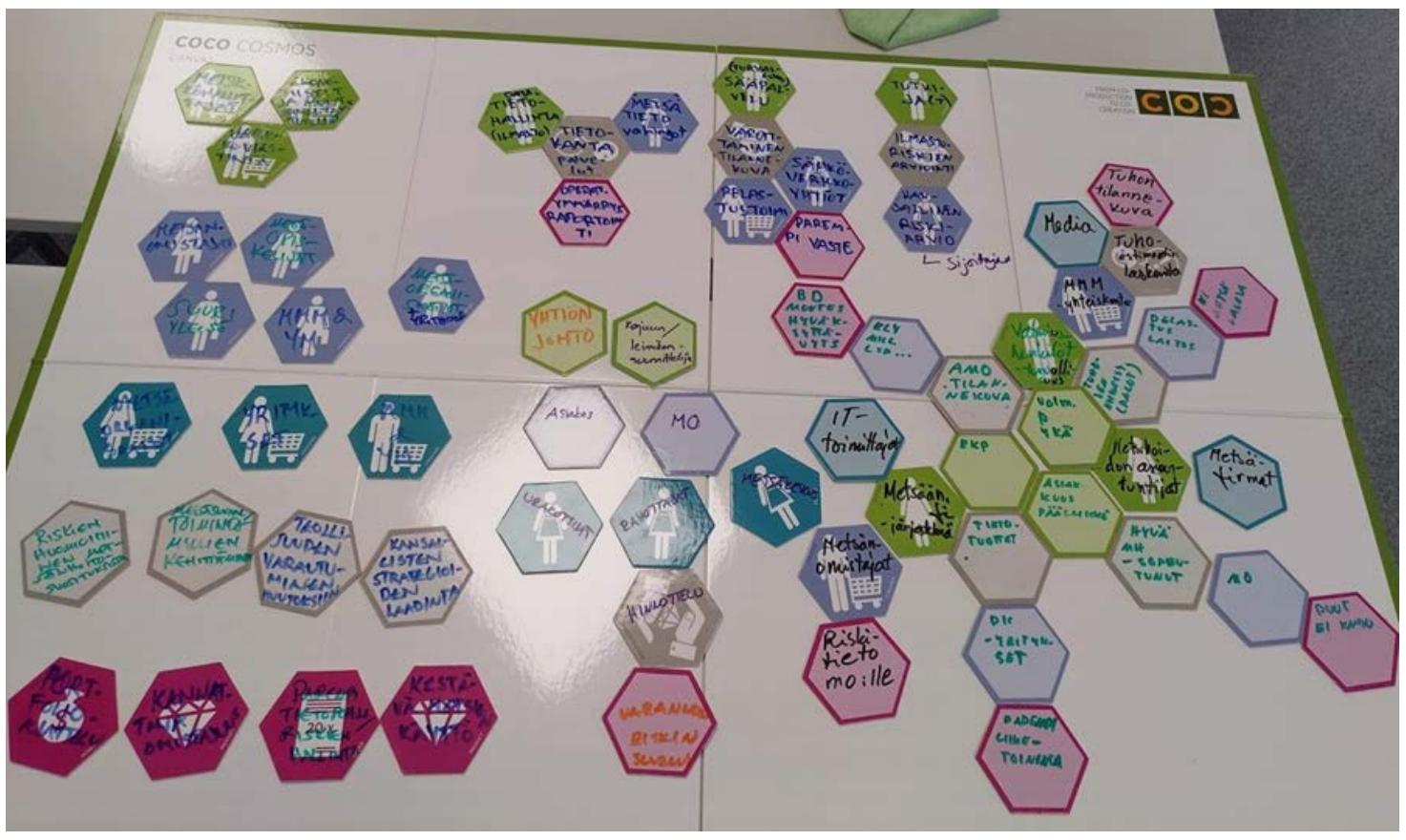

Kuva 5.1. Lumi- ja tuulituhoriskeihin keskittyneen pienryhmän tulokset. 


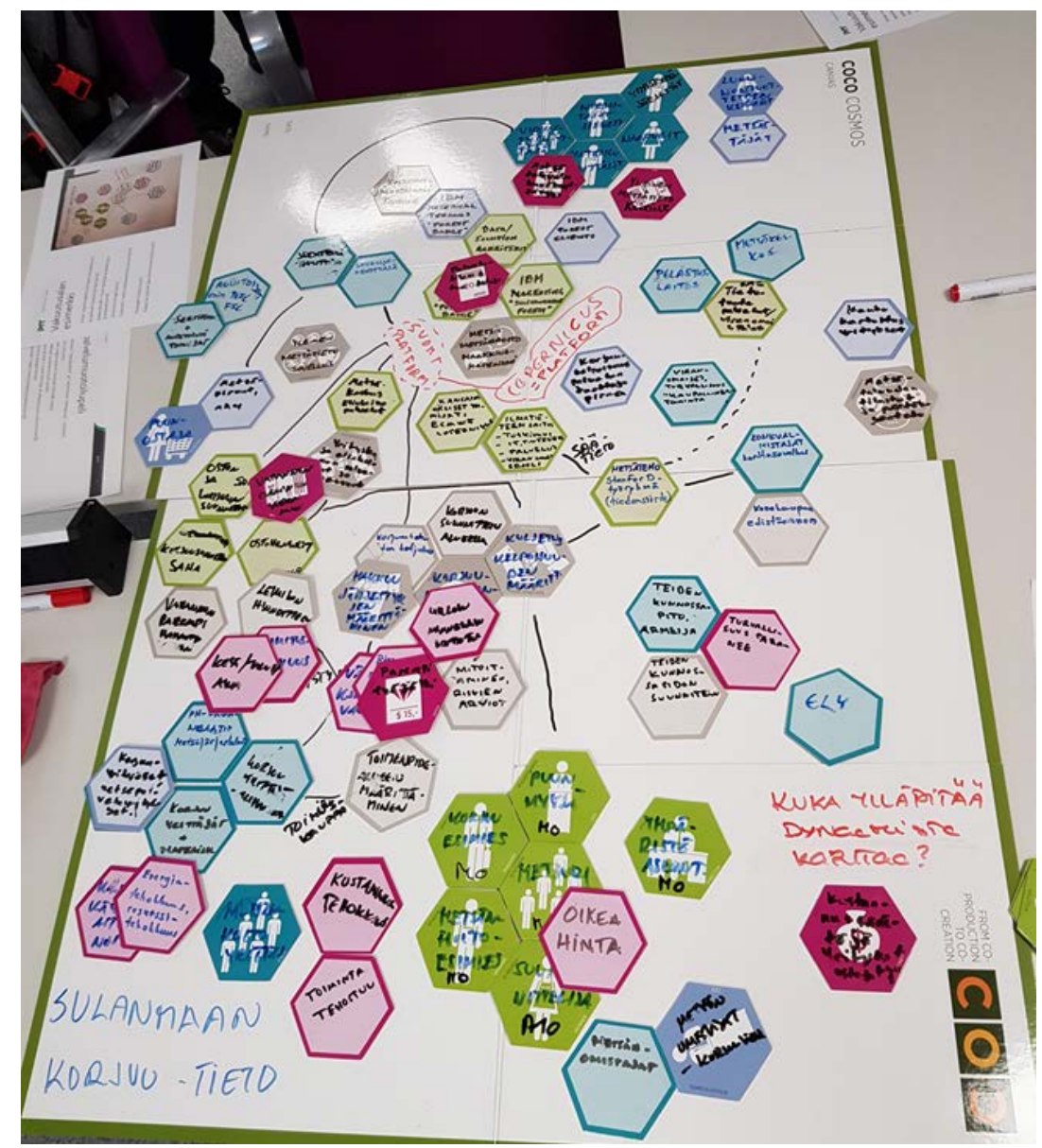

Kuva 5.2. Sulan maan korjuukantavuustietoon keskittyneen pienryhmän tulokset.

Ryhmässä herättivät keskustelua etenkin palvelun tarjoamiseen liittyvät käytännön kysymykset. Tiedon ylläpitäminen, päivittäminen ja jakaminen vaatii resursseja. Lähtökohtaisesti ratkaisuna nähtiin ennen kaikkea julkisin varoin ylläpidettävä big data -alusta (esimerkkinä mainittiin Copernicus), joskin tärkeä kysymys on dynaamisen alustan ylläpitäjän löytyminen. Lisäksi ryhmä nosti esiin sen, että tiedon saaminen käyttöön edellyttää erilaisia ratkaisuja erilaisille toimijoille. Yritykset tarvitsevat tietoaineiston rajapinnan, jotta voivat yhdistää tiedon omiin järjestelmiinsä, kun taas toisille käyttäjille tulee tarjota käyttäjäystävällisiä, mahdollisesti kaupallisia sovelluksia.

\subsection{Tietotuotteiden peruskäyttö voisi olla toivotusti ilmaista, mutta lisäominaisuudet maksullisia}

Tietotuotteiden kestävä ja kannattava hinnoittelu on haasteellista. Tiedon arvo riippuu sen hyödystä, jota on vaikea luotettavasti mitata. Taloustieteellisessä kirjallisuudessa korostetaankin tiedon erityislaatua taloudellisena hyödykkeenä (esim. Wdowin ja Diepeveen 2020).

Hankkeessa kehitettiin uusia metsäbiotaloutta tukevia palveluita ja kartoitettiin niitä tukevia jo olemassa olevia avoimia tietoaineistoja. Näiden palveluiden hyödyllisyyttä kohderyhmille arvioitiin laajoissa haastatteluissa ja työpajassa. Hyödyllisyyden lisäksi pyrittiin selvittämään maksuhalukkuutta eli sitä, voisiko näitä uusia palveluita tehdä maksullisiksi osana muita maksullisia palveluita tai luoda niistä omia maksullisia palveluita. 
Patel (2013) esittää eri tiedon kaupallistamisen lähtökohtia. Hänen mukaansa tiedon kaupallistamisessa voidaan pyrkiä keräämään ja kokoamaan uutta tietoa. Tietoa voidaan myös suodattaa, tarkentaa, parantaa tai rikastuttaa. Sen saatavuutta voidaan helpottaa tai sitä voidaan turvata tai säilyttää. Tietoa voidaan myös analysoida valmiiksi tai sitä voidaan sotkea.

Keskeisenä tuloksena niin haastatteluista kuin työpajasta saatiin, että käyttäjät näkivät tarkastellut tietotuotteet hyödyllisinä ja tarpeellisina. Sekä lumi- ja tuulituhoriskejä että maan kosteus- ja korjuuolosuhteita kuvaaville tiedoille löytyi rajattuja kohderyhmiä, jotka näitä tietoja voisivat hyödyntää. Haastattelut ja työpajaan osallistuneet kykenivät myös esittämään tarpeita, kuten ajantasaisuus, kattavuus, tarkkuus ja mobiilikäytettävyys, jotka osoittavat näkemystä tiedon käyttötarkoituksen alustavasta hahmottamisesta.

Tietotuotteen sisällön ja potentiaalisten käyttötapojen selvittäminen mahdollistaa kaupallistamisen mahdollisuuksien tarkemman analysoinnin. Kaupallistamisen lähtökohdissa pitää ottaa huomioon tiedon erityisluonne hyödykkeenä. Noudattaen Shapiron ja Varianin (1998) esittelemää määritelmää tiedolla, tarkoitetaan sillä tässä digitaalisessa muodossa olevaa dataa.

Keskeisiä piirteitä tämän tyyppiselle tiedolle on, että kulutuksen estäminen (eli poissulkeminen) ei-maksavilta asiakkailta on usein vaikeaa. Lisäksi tietotuotteiden kuluttaminen ei vähennä muiden tuotteiden samanaikaista kuluttamista eli tuote on non-rivalry.

Tietotuotteiden tuotantokustannukset eroavat perinteisistä hyödykkeistä monella tavalla. Niiden tuottamisen kiinteät kustannukset ovat usein korkeat ja niihin liittyy merkittäviä uponneita kustannuksia. Kun tuote on valmis ja sähköisessä muodossa sen marginaalikustannus on usein alhainen, mahdollisesti ilmainen. Lisäksi tuotannolla ei usein ole ylärajaa, vaan tuotteita voidaan valmistaa rajattomasti. Toisaalta tilanteessa, jossa tuotteiden valmistaminen, jakelu tai käyttö vaativat erityisen alustan, tämä synnyttää lisäksi lukitusvaikutuksen. Tuotteella on myös usein verkostovaikutusta, eli sen käyttäminen ja sen hyödyntäminen vaatii muita samoja tai täydentäviä hyödykkeitä.

Haastatteluissa nyt tarkasteltujen tietotuotteiden osalta korostuivat rinnakkaisen ja täydentävien aineistojen tarve, jotta arvoa voitaisiin luoda. Lisäksi korostuivat näiden kanssa yhteisten alustojen ja käyttöliittymien tarve, jotta tietotuotteita voitaisiin hyödyntää. Osaksi tämän takia ilmoitettu maksuhalukkuus vain nyt tarkastelluista tuotteista oli alhainen.

Tietotuotteiden hinnoitteluvaihtoehdot voidaan jakaa viiteen päätyyppiin: tilausmalliin, dynaamiseen hinnoitteluun, huutokauppaan, palveluhinnoitteluun tai freemium-malliin. Tilausmallissa asiakkaalla on monta tapaa maksaa oikeudesta käyttää tietotuotetta. Tietotuotteen voi saada käyttöön kertamaksulla tai aikaperusteisella veloituksella. Myös käyttömäärään liittyvä veloitus on yleinen tilausmallissa.

Dynaamisessa hinnoittelussa tuotteen hinta muuttuu eri tekijöjen mukaan. Näitä tekijöitä voi olla ajankohta, yhteydenottojen lukumäärä, muu kysyntä yms. Dynaamisessa hinnoittelussa käytetään usein jotain seuraavassa esiteltävistä vaihtoehdoista. Pitkässä hännässä tarjottu hinta rakennetaan saatavilla olevien muiden tuotteiden kautta. Erityisesti pyritään arvioimaan, kuinka paljon muiden tuotteiden läsnäolo muuttaa kuluttajan arvonmuodostusta. Joustoihin perustuvassa hinnoittelussa arvioidaan kuluttajan ominaisuuksissa tapahtuvien muutosten vaikutusta maksuhalukkuuteen. Monikanavahinnoittelussa haetaan hinnoittelua off- ja onlinehintoja vertaamalla.

Huutokauppamekanismi on yleistynyt sähköisillä markkinapaikoilla erityisesti yksittäisten hyödykkeiden hankinnassa. Huutokaupalla pyritään ostajaa paljastamaan maksuhalukkuutensa ja käytetty mekanismi vaikuttaa sekä ostajien käyttäytymiseen että vaihdossa syntyneen ylijäämän jakoon. Käytössä on useita huutokauppamekanismeja, joista yleisimpiä ovat 
englantilainen, hollantilainen, sinetöity korkein tarjous tai Vickeroy-huutokauppa (ks. Haeringer, 2017).

Koska haastatteluissa korostettiin alhaista maksuvalmiutta esitellyistä tietotuotteista, kaupallistamisen vaihtoehtona voi toimia nk. ”freemium”-malli (Seufer, 2017). Tässä mallissa perustuotteen käyttö on ilmaista, mutta ominaisuuksista tai käyttökokemuksen parantamisesta pitää maksaa erikseen.

Ominaisuuksia, jotka voidaan tehdä maksullisiksi, ovat esimerkiksi tiedon ajankohtaisuus tai tiedon rakenteen tarkkuus. Freemium-hinnoittelun lähtökohta on, että tarjoamalla tuote ilmaiseksi, sille saadaan laajin mahdollinen käyttäjäkunta. Kun kaikki tuotteesta arvoa saavat ovat ottaneet sen käyttöön, pyritään muuttamaan osa ilmaiskäyttäjistä maksaviksi asiakkaiksi heidän maksuhalukkuutensa pohjalta. Varsinkin mobiilisovelluksissa Freemium-hinnoittelussa on havaittu nk. viiden prosentin sääntö eli käyttäjistä vain viisi sadasta kuluttaa rahaa tuotteeseen. Lisäksi näiden maksavien asiakkaiden joukossa käytetty rahamäärä vaihtelee voimakkaasti. Freemium-mallissa ostaminen voidaan myös pilkkoa osiin ja tuoda tuotteen sisälle osaksi käyttöä.

Freemium-mallin etuina voidaan pitää, että usein ilmaiskäytön kautta konvergoituvat maksavat asiakkaat tuottavat enemmän kuin välittömästi maksavan tuotteen pienempi käyttäjämäärä. Lisäksi ilmaisasiakkaiden synnyttämä tieto tietotuotteen käyttötavoista mahdollistaa tarkemman hinnoittelun ja tuotteen parantamisen uusissa versioissa. Näin käyttötapoja analysoimalla voidaan tukea segmentointia, tarkempaa hinnoittelua ja edistää lisämyyntiä.

Freemium-mallien ympärille rakennettu analytiikka mittaa usein uusien käyttäjien määrää, päivittäistä käyttömäärää, pysyvyyttä ja vaihtuvuutta. Sen jälkeen, kun käyttäjä on muuttunut maksavaksi asiakkaaksi, mitataan myös rahallista sessiometriikkaa ja dynaamista tulonmuodotusta.

Hinnoittelun ei tarvitse riippua tietotuotteesta itsessään vaan tuotteen voi rahoittaa joku muu sitä käyttävä taho. Näitä vaihtoehtoja ovat sisältö- ja mainosrahoitteisuus tai sponsorointi.

Haastattelujen ja työpajan pohjalta freemium-malliin perustuva tuotteistaminen tarjoaa luontevimman mahdollisuuden tietotuotteen jatkokehittelyyn.

Maksullisuuden rakentaminen tietotuotteen osaksi ei ole kuitenkaan ainoa vaihtoehto taloudellisen hyödyn saamiseksi. Esim. Lanelyn (2017) mukaan tietotuotteiden kaupallistamisessa on mahdollisuus monentyyppiseen liiketoimintamallien innovointiin muistakin kuin maksullisuuden lähtökohdista. Lanely (2017) väittää, että tietotuotetta ei tarvitse myydä rahan saamiseksi vaan sitä voidaan jakaa päätuotteen tukena. Tietoa voi käyttää myös vaihdon välineenä, jolloin taloudellinen arvo perustuu vastapuolelta saadun vastapalvelun tai hyödykkeen arvoon. Lanely (2017) korostaa erityisesti tiedon vaihdon merkitystä arvon luonnissa tiedolla rikastetuissa palveluissa. Näitä mahdollisuuksia tulisi myös tarkastella jatkossa.

\section{Suosituksia jatkotoimenpiteille}

- Lumi- ja tuulituhoriskitietoa tulisi jatkokehittää tukemaan metsänhoidon käytännön riskienhallintaa.

- Sulan maan korjuukelpoisuusaineistoa tulisi jatkokehittää tukemaan käytännön työtä.

- Eritysesti suurien metsäbioalan toimijoiden käyttöön sopivaa tuulituhoriskien arviointityökalun kehittämistä tulisi jatkaa.

- Työtä myrskyn jälkeisten tuulituhoalueiden kartoittamiseksi tulisi jatkaa. 
- Ilmastonmuutokseen varautumisen suunnittelua ja sen tarvitsemaa tiedon kokoamista tulisi tehostaa.

- Tietotuotteiden kehittämisessä tulisi hyödyntää kansalaistiedettä ja sidosryhmäyhteistyötä.

- Säätyö-hankkeessa kehitettyjä työkaluja voitaisiin kehittää palveluiksi monin eri tavoin.

Hankkeessa toteutettujen haastattelujen mukaan suurin osa haastateltavista koki, että etenkin lumi- ja tuulituhoriskiä sekä maan korjuukelpoisuutta koskevia tietotuotteita olisi mahdollista kehittää kohti kaupallistamista. Vaikka tiedosta sellaisenaan ei oltu valmiita maksamaan ja sen toivottiin olevan kaikille avointa, maksuhalukkuutta voisi ilmetä liittämällä tietoon lisähyötyä tuovia palveluja. Alla on kuvattu hankkeessa tehtyjen haastattelujen sekä muiden asiantuntijaarvioiden pohjalta tunnistettuja tietotuotteiden ja -palveluiden jatkokehityskohteita. Näiden arvioidaan tuovan lisäarvoa metsäbiotalouden toimijoille. Taulukkoon 6.1 on kerätty kehityspolkuja hankkeessa kehitettyjen työkalujen saattamiseksi palveluiksi.

\section{Lumi- ja tuulituhoriskitietoa tulisi jatkokehittää tukemaan metsänhoidon käytännön riskienhallintaa}

Haastatteluissa ehdotettiin, että lumi- ja tuulituhoriskitiedon jatkokehitystyössä kannattaisi kartta-aineistoon liittää selväkielinen ohjeistus siitä, mitä korkea riskitaso tarkoittaa käytännön metsänhoidossa eri kohteissa. Myös linkki sähköisten metsänhoidon suositusten avainkohtiin voisi olla hyödyllinen, etenkin metsänomistajakäyttäjille.

Useampi haastateltava koki, että riskitieto kannattaisi sisällyttää sähköisiin metsäsuunnitelmiin. Sähköinen metsäsuunnitelma voisi sisältää ilmoituspalvelun, joka toimenpiteitä suunnitellessa hälyttäisi käsittelykuvion (tai naapurikuvioille aiheutuvasta) korkeammasta tuhoriskistä. Metsänomistajien maksuhalukkuutta voisi nostaa myös palvelu, joka hälyttäisi tuhoa aiheuttavista sääolosuhteista, laskisi tuhoennusteen kulloinkin vallinneilla olosuhteilla ja tarjoaisi tiedon todennäköisimmistä tuhon sijaintipaikoista. Tällaisen tiedon käyttäjinä mainittiin myös tuhopuun korjuuta suunnittelevat ja tekevät tahot.

Yleisesti ottaen lisäpalvelujen potentiaalisina käyttäjinä nähtiin etenkin ammattimaisesti metsiään hoitavat metsänomistajat, esimerkiksi metsärahastot. Heidän lisäkseen etämetsänomistajia saattaisi kiinnostaa palvelu, joka tuholle suotuisten olosuhteiden jälkeen tekisi tuhopuukartoituksen esim. satelliittikuvien pohjalta ja tarjoaisi myös mahdollisten tuhojen korjuutyön. Eräs haastateltava näki, että metsänsä heikommin tuntevia metsänomistajia varten tulisi riskitietoa ja toimenpiteiden vaikutuksia muuttaa visuaaliseen muotoon esimerkiksi virtuaalimetsäsovellusten avulla.

Kaukokartoitusmenetelmien hyödyntämistä metsätuhojen tunnistuksessa tulisi jatkossa käyttää myös valtakunnallisten tuhoarvioiden tekoon. Tulevaisuudessa avainkysymykseksi muodostuu se, millaisia hyönteistuhoja sääilmiöistä johtuvat metsätuhot synnyttävät. Hyönteistuhojen kontrolloimiseksi pitäisi tuhoja kärsineitä metsänomistajia herätellä kohdennetulla viestinnällä ja motivoida korjaamaan tuhopuuta pian tuhojen synnyttyä. Haastatteluissa tuotiin esiin myös tarve kerätä yhteen ja jalostaa pidemmälle tietoa hyönteistuhojen alueelliseen todennäköisyyteen vaikuttavista tekijöistä.

Lumituhoennusteet valtakunnallisena karttapalveluna sekä myrskytuulten tilannekuva ovat varmasti yleisesti kiinnostavia asiaan vihkiytyneille kansalaisille ja ammattilaisille. Onkin perusteltua julkaista ne avoimena palveluna sitten, kun ne ovat valmiita. Varsinainen hyöty tietotuotteista saavutetaan metsäkeskuksen viranomaistyössä ja metsätaloutta edistävässä viestinnässä. Esimerkiksi talven mittaan kumuloituvaa lumituhoriskiä voidaan seurata 
metsäkeskuksessa. Muuhun tietoon (esimerkiksi metsänkäyttöilmoitukset, yhteydenotot ammattilaisilta, kaukokartoitusaineistot) yhdistettynä tehdään tilannearvio, jossa päädytään toimenpiteisiin. Toimenpide voisi olla esimerkiksi kohdentaa tuhoriskialueen metsänomistajille tiedote tilanteesta ja neuvoa, miten kannattaisi toimia (esimerkiksi tekstiviesti: "xx alueella, jossa omistat metsää, on tänä talvena merkittävä lumituhoriski. Suosittelemme että tarkistat metsiesi tilan, kun lumet ovat sulaneet. Lisätietoja Metsään.fi. Muista turvallisuus!”). Lisäksi viestissä voisi olla linkki tuhoriskikarttaan, jonka avulla metsänomistaja voisi etukäteen katsoa oman metsätilansa riskialttiimmat kohdat. Vastaavasti voidaan viestiä alueen metsätalouden toimijoille (metsänhoitoyhdistykset, puunkorjuuyritykset jne.) ja paikalliselle medialle. Vastaavasti toimisi myrskytuulten tilannekuva.

Työkaluja voisi hyödyntää yhdessä metsätiedon ja muiden mallien kanssa kehitettäessä ilmastonmuutoksen sopeutuvia metsänhoitosuosituksia. Suositukset otettaisiin käyttöön koulutuksin ja selkeillä metsänkäsittelysuosituksilla Metsään.fi-palvelussa.

\section{Sulan maan korjuukelpoisuusaineistoa tulisi jatkokehittää tukemaan käytännön työtä}

Sulan maan korjuukelpoisuusaineistoa ja sen jatkokehitystä koskien haastatteluissa nousi esiin tarve sitä hyödyntäville optimointityökaluille, jotka tukisivat hakkuiden, korjuun ja kuljetuksen käytännön toteutusta eri tasoilla.

Leimikkotasolla todennäköisesti märimpien ja kuivimpien pisteiden tunnistaminen ja tuominen paikkatietomuotoon nähtiin yksinkertaisena tapana tuottaa lisäarvoa. Pidemmälle vietynä kehitystyönä nostettiin esiin ajouraoptimointi, jonka toteutusvaihtoehtoja Metsäteho on tutkinut Ajourakone-sovelluksella. Leimikkotason ajourasuunnittelun merkityksen nähtiin korostuvan tulevaisuudessa muun muassa jatkuvan kasvatuksen yleistymisen takia. Myös korjuujäljen vaikutus asiakastyytyväisyyteen ja kilpailuun metsänomistaja-asiakkaista nähtiin tärkeänä syynä panostaa leimikkotason korjuusuunnitteluun.

Alueellisella tasolla nostettiin esiin tarve tukea korjuu- ja kuljetuskohteiden toteutusjärjestyksen valintaa. Kullakin hetkellä korjuuseen tai kuljetukseen soveltuvat kohteet olisi mahdollista tunnistaa yhdistämällä asiakkaiden tarpeisiin eri tietoja. Tällaisia tietoja ovat esimerkiksi maan kosteus ja sen ennuste, kosteuden vaikutus leimikon kantavuusominaisuuksiin ja tiestön kantavuusominaisuuksiin sekä leimikolta saatavat puutavaralajit. Optimointityökaluun liittyvä hälytysjärjestelmä, joka reagoisi muuttuviin tai ennustettuihin sääolosuhteisiin, nähtiin myös hyödyllisenä. Tämän kaltaiseen, toimivaan tietotuotteeseen todettiin useammassa haastattelussa kohdistuvan maksuhalukkuutta.

Edellä kuvattujen, mahdollisesti kaupallisten tietotuotteiden käyttäjinä nähtiin ennen kaikkea metsäteollisuuden raakapuun ostoa, hakkuuta, korjuuta ja kuljetusta tekevät operatiiviset toimijat.

Lisäksi Metsäkeskuksen kanssa käydyissä keskusteluissa nousi esiin mahdollisuus hyödyntää maan kosteustietoa luonnontuotealalla. Maanpinnan kosteustiedosta voisi olla hyötyä esimerkiksi marjasadon alueellisen vaihtelun ennustamisessa siten, että kuivana vuotena mustikankeruuta voisi kohdentaa alueille, missä on keskimääräistä kosteampaa maastoa. Kuitenkin pölytyksen onnistuminen lienee suurin tekijä mustikkasadossa ja muissakin marjoissa. Pitää myös tietää kasvaako näillä kosteudeltaan sopivalla alueella kiinnostuksen kohteena olevia marjoja. Marjasatoa tai muita luonnontuotteita koskevia malleja, joihin yhdistetään säätietoa, on tutkimuksen ja kehittämistyön kohteena Lukessa. Työkalun ominaisuuksista olisikin hyvä olla tieto näitä malleja kehittävillä tutkijoilla.

Kesäkaudelta 2020 kerätyn toteumatiedon analyysi tulee antamaan hyvän kuvan tämänhetkisten kosteusennusteiden soveltuvuudesta kantavuusolosuhteiden arviointiin. 
Aineistolla voidaan tehdä myös jatkoanalyysejä, joissa kytketään tähän mennessä käytettyjen ennusteiden rinnalle myös maaperätietoa sekä Luken syksyllä 2020 julkaisemat DTWkosteusindeksikartat. Topografiaan perustuvat kartat kuvaavat kosteusriskialueita neljässä eri kosteusolosuhteessa.

Dynaamisten korjuukeliennusteiden kehitystyö ja todennäköisesti myös valmiiden mallien ylläpito ja kalibrointi tulee vaatimaan jatkossakin tuekseen systemaattista ja ajantasaista tietoa ennusteiden osuvuudesta. Tähän on syytä varautua kehittämällä kantavuustietoa tuottavia, esimerkiksi korjuukoneiden voimansiirrosta kerättävään tietoon perustuvia automaattisia tiedonkeruumenetelmiä. Tällaisia kehityshankkeita on meneillään ja tulosten jalkauttamiseksi on tehtävä sekä standardointi- että järjestelmätyötä.

\section{Eritysesti suurien metsäbioalan toimijoiden käyttöön sopivaa tuulituhoriskien arviointityökalun kehittämistä tulisi jatkaa}

Tuulituhoriskityökalu on tällä hetkellä testiversio ja vaatii käyttöliittymäkehitystä ja testausta, ennen kuin sitä voidaan jakaa laajemmalle käyttäjäkunnalle. Tulevaisuudessa työkalusovellusta tulisi kehittää siten, että metsänomistaja tai metsäammattilainen voisi käyttää sitä apuna, esimerkiksi leimikonsuunnittelussa, tuulituhojen vähentämiseksi riskille alttiissa kohteissa. Leimikon suunnittelussa etenkin isot metsänomistajat, joiden tiloilla hakkuusuunnittelua tehdään useammin, voisivat hyödyntää tuulituhomallia. Työkalu auttaisi rajaamaan leimikkoa niin, etteivät hakkuun viereiset puustot olisi herkkiä tuulituhoille. Pienillä metsätiloilla, joita siis on suurin osa Suomen talousmetsistä, tuulituhon mallinnustyökalun hyödyntämismahdollisuudet ovat rajallisempia.

Monet hyödylliset tietotuotteet kehitetään parantamaan metsien käsittelyn tuloksellisuutta ja laatua. Yksittäisen hakkuun kohdalla on mahdollista ottaa huomioon optimaalinen säästöpuiden ryhmittely esimerkiksi monimuotoisuuden (jatkumot) tai vesiensuojelun (säätöpuiden sijoittelu eroosioherkälle kohdalle kuviota) näkökulmasta. Ideaalitilanteessa hakkuut voisi sijoitella ja ajastaa valuma-alueella niin, että vaikutukset vesistöihin minimoituvat. Olisi hyvä, jos samaan aikaan voisi ottaa huomioon tuulituhoriskit tai maisemaarvot vesistöreitillä purjehtivan näkökulmasta. Oleellinen tieto tulisi voida tarjota kuhunkin tilanteeseen lukuisten päätöstyökalujen kirjastosta. Toisaalta, jos kuvioiden tietty käsittelyn järjestys olisi hyvää tuulituhojen ehkäisyä, miten sopia asiasta, kun alueella on useita metsänomistajia. Käyttäjien tulisi voida ladata tarvittavat metsikkö- ja puusto- ym. tiedot avoimista tietolähteistä. Lisäksi sovelluksen tulisi kyetä sijoittamaan koealoja (pisteitä) alueelle tarvittaessa eri tavoilla, esimerkiksi satunnaisesti, säännöllisin välimatkoin tai painottaen metsikkökuvioiden reunoja (suurin tuulituhoriski on uusien aukkojen läheisyydessä). Lisäksi tulisi laskennassa voida käyttää mikrokuvioiden keskitunnusten sijaan niiden jakaumatietoa. Sovelluksen tulisi myös kyetä automaattisesti laskemaan tuulikenttä alueelle ja päivittämään se, kun alueella on tehty hakkuita (tässä työversiossa tätä mahdollisuutta ei vielä ole). Tuulituhoriskejä laskettaessa olisi otettava huomioon myös se, että esimerkiksi järven rannalla tai pellon reunassa puusto on ehtinyt sopeutua vallitsevaan tuuli-ilmastoon ja voi näin ollen tarvita suurempia tuulennopeuksia tuhoon, kuin uuden avohakkuualan reunassa (mitä ei nyt huomioitu). Myös käyttöliittymän kehittäminen käyttäjäystävälliseksi on tarpeellista jatkossa.

\section{Työtä myrskyn jälkeisten tuulituhoalueiden kartoittamiseksi tulisi jatkaa}

Analysoimalla havaittuja maksimipuuskia saadaan yleiskäsitys alueista, joilla voimakkaimmat puuskat ovat myrskyn aikana puhaltaneet. Tuulituhojen kannalta oleellista on myös tieto metsien haavoittuvuudesta tuulituhoille. Nämä kaksi tietoa yhdistämällä, eli myrskyn aikaisten maksimipuuskien alueellinen jakauma sekä tieto metsien herkkyydestä tuulituhoille, voidaan 
päästä parempiin tuloksiin myrskyn jälkeisten potentiaalisten tuulituhoalueiden kartoittamisessa.

Toinen lähestymistapa myrskyalueiden paikantamiseksi on hyödyntää numeeristen sääennustemallien tuottamia tuulikenttäanalyysejä. Tätä on testattu Maa- ja metsätalousministeriön rahoittamassa Monituho-hankkeessa. Tuhoalueiden kartoittaminen kaukokartoitusmenetelmien avulla tulee mitä ilmeisemmin yleistymään menetelmien kehittymisen myötä. Näin tapahtunee myös tekoälyyn pohjautuvien sovellutusten osalta.

\section{Ilmastonmuutokseen varautumisen suunnittelua ja sen tarvitsemaa tiedon kokoamista tulisi tehostaa}

Ilmastonmuutokseen kytkeytyvän tiedon hyödyntämistä tulisi tehostaa sekä alueellisten että valtakunnallisten sopeutumistoimien suunnittelussa ja toteutuksessa. Lumituhoja, tuulituhoja ja sulan maan olosuhteita ennustavat työkalut voivat olla hyödyllisiä mallinnuksen välineitä alueellisella tasolla. Valuma-alueilla, maisematasolla tai maakunnassa on useita maanomistajia, mikä haastaa yleisen tai yhteisen suunnittelun. Metsäkeskus ei voi nykytilanteessa tehdä alueellista metsäsuunnittelua. Alueellinen metsäohjelma onkin yleisellä tasolla ilman paikkaan sidottuja tietoja. Paikkaan sidottuja ratkaisuja on maakuntakaavassa, mutta metsiin liittyvän päätöksenteon yhteydessä se on kuitenkin hankala väline. Myös pelastusviranomaiset laativat omia suunnitelmiaan paikaan sidottuina.

Yksi tapa koordinoida ilmastonmuutokseen sopeutuvia toimia usean maanomistajan alueella on tehdä alueellinen suunnitelma kuviotietoineen ja pitää tätä neuvoa antavana ja toimenpideehdotuksineen vapaaehtoisena. Silloin kuitenkin suunnitelman tiedot tulisi olla vain maanomistajan tiedossa, jotta päätökset olisivat aidosti vapaaehtoisia. Julkisista merkinnöistä tulee helposti myös julkisia vaatimuksia, jotka kaventavat maanomistajan vaihtoehtoja. Ilmastonmuutokseen sopeutumisen alueellinen suunnittelu vaatiikin vielä kehittämistyötä.

Hankkeen aikana korostui myös tarve tuottaa, koota yhteen ja viestiä valtakunnallisen tason tietoa niistä metsiin kohdistuvista riskeistä, joita ilmastonmuutos tuo. Samaan yhteyteen tulisi systemaattisesti kerätä tietoa toteutuneista metsätuhoista ja niiden taloudellisista seurauksista. Näiden pohjalta olisi mahdollista tuottaa arvioita niistä taloudellisista vahingoista, joita riskit voivat toteutuessaan aiheuttaa. Tämä havainnollistaisi tiedon kehittämisestä ja käytöstä saatavia hyötyjä, ohjaisi kehittämisresursseja sekä kannustaisi uusien tietotuotteiden käyttöön. Yhteisen, valtakunnallisen tietokannan nähtiin myös edistävän eri sidosryhmien yhteistyötä. Meneillään oleva vaikutustietokantojen kehittäminen tukee tätä kehitystä.

\section{Tietotuotteiden kehittämisessä tulisi hyödyntää kansalaistiedettä ja sidosryhmäyhteistyötä}

Työkalujen ja mallien testaamista ja kehittämistä varten maastohavainnot ovat arvokkaita. Osittain avoin kysymys on, kuinka voidaan hyödyntää niin sanottua kansalaistiedettä (citizen science) tuhotiedon keruussa? Tällä hetkellä tuhotietoja voi ilmoittaa Metsäkeskuksen kehittämällä Laatumetsä -sovelluksella (https://www.metsakeskus.fi/mobiilipalvelut) tai wwwlomakkeella (https://survey123.arcgis.com/share/79e990328ac2400986df26e7c7af5653). Myös Lukella on www-lomake tuhoista ilmoittamista varten (https://metsainfo.luke.fi/fi/metsatuholomake). Samoin Ilmatieteen laitoksen Sää-sovelluksella voi ilmoittaa omia säähavaintoja Omat havainnot -osiossa. Sovellus on tarjolla Android- ja iOS-laitteille (https://www.ilmatieteenlaitos.fi/omat-havainnot). Tämän sovelluksen kautta voi ilmoittaa esimerkiksi tykkylumitilanteista. 
Tuhotiedot hyödyttävät tutkijoita ja viranomaisia ja yhteinen tietojen vastaanotto helpottaisi heidän työtään. Tarvitaan myös keinoja arvioida tiedon laatua. Kirjautumisen vaatiman palvelun avulla, voitaisiin kerätä taustoittavia tietoja tekijän tekemistä havainnoista. Tällöin olisi mahdollista palkita hyvälaatuisen tiedon tuottajaa, innostaa pelillisin ominaisuuksin ja palautteella sekä antaa myös vinkkejä (vaikka satelliittitiedon perusteella) minne kansalaisen toivotaan menevän etsimään tuhoja. Kirjautumisen vaatiminen voisi tosin myös vähentää saatavien ilmoitusten määrää.

Osallistavan tiedonkeruun ja kansalaishavaintojen hyödyntämisen lisäksi myös tietotuotteiden ja -palvelujen suunnittelussa on panostettava yhteistyöhön. Tieto luo arvoa silloin, kun sen avulla muutetaan olemassa olevia prosesseja paremmin tavoitteisiin sopiviksi. Tiedon käyttöönottoa ja sitä kautta arvonluontia tukee se, jos tietoa kehitetään ja hyödynnetään yhdessä. Yhteistyöhön tarvitaan sekä tiedon tuottajia että sen käyttäjiä mutta myös muita sidosryhmiä, kuten sovelluskehittäjiä, Tiedon käyttöönottoa ja sitä kautta arvonluontia tukee tiedon ja sen hyödyntämisen säännöllinen kehittäminen yhdessä tiedon tuottajien, käyttäjien ja myös muiden sidosryhmien, kuten sovelluskehittäjien kesken. Tätä tukemaan on kehitetty erilaisia yhteiskehittämistyökaluja ja -alustoja, joiden käyttöönottoon metsäbiotalouden toimijoita tulisi rohkaista.

\section{Säätyö-hankkeessa kehitettyjä työkaluja voitaisiin kehittää palveluiksi monin eri tavoin}

Taulukkoon 6.1 on tiivistetysti kerätty mahdollisia väyliä, joiden kautta hankkeessa kehitetyistä tuotteista on mahdollista kehittää toimivia palveluita. 
Taulukko 6.1. Hankkeessa kehiteltyjen työkalujen polkuja palveluiksi.

\begin{tabular}{|c|c|c|c|c|c|}
\hline Työkalu & \multicolumn{3}{|c|}{$\begin{array}{l}\text { Lumituhomallit } \\
\text { Tuulituhon tilannekuva }\end{array}$} & $\begin{array}{l}\text { Lumituhomallit } \\
\text { Tuulituhon } \\
\text { tilannekuva } \\
\text { Kantavuuden } \\
\text { arviointi } \\
\text { Muut } \\
\text { tietotuotteet }\end{array}$ & $\begin{array}{l}\text { Tuulituhomalli, } \\
\text { leimikon } \\
\text { suunnittelussa } \\
\text { Kantavuuden } \\
\text { arviointi }\end{array}$ \\
\hline $\begin{array}{l}\text { Työkalun } \\
\text { käyttäjä }\end{array}$ & \multicolumn{3}{|c|}{$\begin{array}{l}\text { Metsäkeskuksen viranomaistyö } \\
\text { Yleinen tiedotus }\end{array}$} & $\begin{array}{l}\text { Suuri yleisö } \\
\text { Avoimen datan } \\
\text { käyttäjät }\end{array}$ & $\begin{array}{l}\text { Metsä- } \\
\text { ammattilaiset } \\
\text { (toimijat) } \\
\text { Operaatio- } \\
\text { esimiehet } \\
\text { Palveluntarjoajat }\end{array}$ \\
\hline Tarve & \multicolumn{3}{|c|}{ Yhdessä muun informaation kanssa tilannekuvan luomiseksi } & $\begin{array}{l}\text { Harrastuneisuus } \\
\text { Kiva tietää } \\
\text { Kaupalliset } \\
\text { tuotteet } \\
\text { rajapintojen/ } \\
\text { latausten kautta }\end{array}$ & $\begin{array}{l}\text { Tuuliriskin } \\
\text { hallinnan } \\
\text { mahdollisuus } \\
\text { osana leimikon } \\
\text { suunnittelua. } \\
\text { Kantavuuden } \\
\text { arviointi osana } \\
\text { suunnittelua, kun } \\
\text { on riittävä } \\
\text { leimikkovaranto. }\end{array}$ \\
\hline $\begin{array}{l}\text { Palvelun } \\
\text { tuottaminen }\end{array}$ & \multicolumn{3}{|c|}{ Metsäkeskus tuottaa palveluja kohdennetusti. } & $\begin{array}{l}\text { Metsäkeskuksen } \\
\text { avoimet } \\
\text { palvelutuotteet }\end{array}$ & $\begin{array}{l}\text { Business to } \\
\text { business }\end{array}$ \\
\hline $\begin{array}{l}\text { Lopputuote/ } \\
\text { palvelu }\end{array}$ & $\begin{array}{l}\text { Tilannekohtaiset } \\
\text { tiedotteet: SMK } \\
\text { ottaa yhteyttä } \\
\text { riskialueen } \\
\text { metsänomistajiin, } \\
\text { kun nähtävillä } \\
\text { lumituhoriskejä. }\end{array}$ & $\begin{array}{l}\text { Muu neuvonta } \\
\text { Metsään.fi ja muut } \\
\text { neuvontakanavat } \\
\text { (henkilökohtainen } \\
\text { neuvonta, } \\
\text { koulutukset yms.) } \\
\text { tarjoavat metsän- } \\
\text { käsittelyvaihto- } \\
\text { ehtoja, jotka } \\
\text { lieventävät riskejä. }\end{array}$ & $\begin{array}{l}\text { Malleja } \\
\text { hyödyntämällä } \\
\text { voidaan tuottaa } \\
\text { alueille paikkaan } \\
\text { sidottuja } \\
\text { skenaarioita eri } \\
\text { ilmasto/ } \\
\text { säävaihtoehdoilla. } \\
\text { Tällä taustatyöllä } \\
\text { voidaan tuottaa } \\
\text { alueelliset } \\
\text { varautumis- } \\
\text { suunnitelmat } \\
\text { ilmastonmuutoksen } \\
\text { vaikutuksiin. }\end{array}$ & $\begin{array}{l}\text { Mahdollisuus } \\
\text { uusiin } \\
\text { kaupallisiin } \\
\text { palveluihin } \\
\text { "Harrastajien" } \\
\text { palvelu, palaute- } \\
\text { mahdollisuus, } \\
\text { kansalaistieteen } \\
\text { tuottaman tiedon } \\
\text { vastaanotto }\end{array}$ & $\begin{array}{l}\text { Tarjotaan hyvä } \\
\text { puukaupan } \\
\text { ja -korjuun } \\
\text { asiakaskokemus, } \\
\text { ei tuulenkaatoja } \\
\text { naapurikuviolla. }\end{array}$ \\
\hline $\begin{array}{l}\text { Loppu- } \\
\text { käyttäjä }\end{array}$ & $\begin{array}{l}\text { Metsänomistaja, } \\
\text { joka saa omaa } \\
\text { tilaansa koskevan } \\
\text { tuhotiedon. } \\
\text { Alueen } \\
\text { metsätoimijat } \\
\text { saavat tiedotteen } \\
\text { mahdollisista } \\
\text { tuhoista ja } \\
\text { tuhoalueesta. }\end{array}$ & $\begin{array}{l}\text { Metsänomistaja, } \\
\text { jonka kyvyt } \\
\text { karttuvat } \\
\text { sellaiseen } \\
\text { metsänhoitoon, } \\
\text { joka ottaa } \\
\text { huomioon } \\
\text { ilmastoriskit. }\end{array}$ & $\begin{array}{l}\text { Viranomaiset } \\
\text { Pelastustoimi } \\
\text { Aluesuunnittelu } \\
\text { Aluehallinto }\end{array}$ & $\begin{array}{l}\text { Tutkijat } \\
\text { Metsäkeskuksen } \\
\text { viranomais- ja } \\
\text { tiedotustyö, } \\
\text { informaatiota } \\
\text { tilannekuvan } \\
\text { luomiseksi }\end{array}$ & $\begin{array}{l}\text { Metsänomistaja- } \\
\text { asiakas on } \\
\text { tyytyväinen } \\
\text { laadukkaaseen } \\
\text { työnjälkeen (ei } \\
\text { korjuuvaurioita, } \\
\text { ei tuulenkaatoja } \\
\text { tai tuulituhoja). }\end{array}$ \\
\hline
\end{tabular}




\section{Kiitokset}

Kiitämme Ilmatieteen laitokselta Ilari Lehtosta raportin tarkastamisesta sekä lumituhomallin kehitykseen liittyvästä työstä. Kiitämme myös Ari-Juhani Punkkaa, Tuomo Bergmania, Andrea Vajdaa ja Heikki Tuomenvirtaa saamistamme hyödyllisistä kommenteista ja materiaalista.

Haluamme kiittää Itä-Suomen yliopiston metsätieteiden osastosta tutkija Veli-Pekka Ikosta, tutkijatohtori Ranjith Gopalakrishnania ja professori Petteri Packalenia tuulituhoriskimallin kehitykseen osallistumisesta.

Lumituhoriskimallin kehityksessä on hyödynnetty Valtion Metsien Inventointiaineistoja (VMI) ja haluammekin kiittää Luonnonvarakeskuksen tutkija Mikael Strandsrömiä. Lumikehämallin kehitykseen ovat osallistuneet myös Aleksi Lehtonen (Luonnonvarakeskus) sekä Heli Viiri (UPM), Suomen metsäkeskuksesta Miia Saarimaa ja Mikko Kesälä ovat olleet kehittämässä lumituhokarttapalvelua. Raportin sisältöihin arvokkaita kommentteja ja täydennyksiä ovat antaneet: Heikki Karppinen, Juha Vornanen, Juha Tuononen, Ilpo Rautio ja Jouni Aila.

Kiitämme myös hankkeen ohjausryhmän jäseniä Erno Järvistä (MTK), Anu Islanderia (Metsäteollisuus), Timo Makkosta (Koneyrittäjät) ja Pietari Niemeä (Westas Group) sekä Tatu Torniaista (MMM).

Raportti on tehty pääasiassa maa- ja metsätalousministeriön rahoittaman hankkeen Säätyö myötävaikutuksella. Tuulituhoriskityökalun kehitystyöhön on tukea saatu myös Suomen Akatemian yhteydessä toimivan Strategisen tutkimuksen neuvoston rahoittamasta FORBIOhankkeesta (päätös 314224).

\section{Kirjallisuusluettelo}

Aalto, J., Pirinen, P., Heikkinen, J. and Venäläinen, A., 2012. Spatial interpolation of monthly climate data for Finland: comparing the performance of kriging and generalized additive models. Theor Appl Climatol., 112 (1-2), 99-111. DOI 10.1007/s00704-012-0716-9.

Aalto, J., Pirinen, P. and Jylhä, K., 2016. New gridded daily climatology of Finland: Permutation-based uncertainty estimates and temporal trends. J. Geophys. Res. Atmos., 121(8), 3807-382, doi:10.1002/2015JD024651.

Eeronheimo, O. 1991. Suometsien puunkorjuu. Folia Forestalia, 779. 29 s.

Gopalakrishnan, R., Packalen, P., Ikonen, V.-P., Räty, J., Venäläinen, A., Laapas, M., Pirinen, P., Peltola, H. 2020. The utility of fused airborne laser scanning and multispectral data for improved wind damage risk assessment over a managed forest landscape in Finland. Annals of Forest Science Annals of Forest Science 2020 77:97, https://doi.org/10.1007/s13595-020-00992-8. .

Haeringen, G. 2017. Market Design - auctions and matching. MIT Press.

Heino, E. \& Pouttu, A. (toim.), 2014. Metsätuhot vuonna 2013. Metlan työraportteja / Working Papers of the Finnish Forest Research Institute 295. 28 s. ISBN 978-951-40-2474-0 (pdf). Saatavissa: http://www.metla.fi/julkaisut/workingpapers/2014/mwp295.htm.

Heinonen, T., Pukkala, T., Ikonen, V.-P., Peltola, H., Venäläinen, A., Dupont, S., 2009. Integrating the risk of wind damage into forest planning. Forest Ecology and Management 258(7):1567-1577. 
Honkanen, M., 2019. Luonnontuotealan toimialaraportti 2019. Työ- ja elinkeinoministeriön julkaisuja Toimialaraportti 2019:32, http://urn.fi/URN:ISBN:978-952-327-428-0.

Hyvärinen, O., Venäläinen, A. and Vajda, A., 2020. Bias-adjusted seasonal forecasts of soil moisture for forestry applications in Finland. Adv. Sci. Res., 17, 23-27, 2020, https://doi.org/10.5194/asr-1723-2020.

Laapas, M., ym., 2021. Combining interpolated wind gust speed and forest vulnerability data to highlight potential forest damage areas related to wind storms. Manuscript in preparation.

Lanely, D. 2017. Infonomics. Gartner inc.

Laurila, T., Sinclair, V. and Gregow, H., 2020. Climatology, variability and trends in near-surface wind speeds over the North Atlantic and Europe during 1979-2018 based on ERA5. (JOC-20-0587.R1, Accepted 30.11.2020).

Lehtonen I, Hoppula P, Pirinen P, Gregow H, 2014. Modelling crown snow loads in Finland: a comparison of two methods. Silva Fennica vol. 48 no. 3 article id 1120 http://dx.doi.org/10.14214/sf.1120

Lehtonen, I., Kämäräinen, M., Gregow, H., Venäläinen, A. and Peltola, H., 2016. Heavy snow loads in Finnish forests respond regionally asymmetrically to projected climate change, Nat. Hazards Earth Syst. Sci., 16, 2259-2271, doi:10.5194/nhess-16-2259-2016.

Lehtonen, I., Venälänen, A., Kämäräinen, M., Asikainen, A., Laitila, J., Anttila, P. and Peltola, H., 2018. Projected decrease in wintertime bearing capacity on different forest and soil types in Finland under warming climate. Hydrol. Earth Syst. Sci. Discuss., https://doi.org/10.5194/hess-2017-727.

Lehtonen, I., Venäläinen A. ja Gregow, H., 2020. Ilmastonmuutoksen vaikutukset Suomessa metsänhoidon näkökulmasta. Ilmatieteen laitos, Raportteja 2020:5, https://doi.org/10.35614/isbn.9789523361270

McCallum, Q.E. and Gleason, K. (2013). Business Models for the Data Economy. O’Reilly.

MMM, 2019. Kansallinen metsästrategia 2025 - päivitys. Valtioneuvoston periaatepäätös 21.2.2019. Maa- ja metsätalousministeriön julkaisuja 2019:7.

Peltola, H., Ikonen, V-P., Gregow, H., Strandman, H., Kilpeläinen, A., Venäläinen, A., Kellomäki, S., 2010. Impacts of climate change on timber production and regional risks of wind-induced damage to forests in Finland. Forest Ecology and Management 260(5):833-845.

Peltola, H., Kellomäki, S., Väisänen, H., Ikonen, V-P., 1999. A mechanistic model for assessing the risk of wind and snow damage to single trees and stands of Scots pine, Norway spruce and birch. Canadian Journal of Forest Research 29:647-661.

Rantanen, M., Laurila, T., Sinclair, V. and Gregow, H., 2021. Storm Aila: unusually strong autumn storm in Finland, Weather (under review).

Seufert, E. 2013. Freemium Economics. Morgan Kauffman.

Shapiro, C. and Varian, H. 1998. Information economics. Harvard University Press.

Solantie, R., 1994. Effect of weather and climatological background on snow damage of forests in Southern Finland in November 1991. Silva Fennica, 28: 203-211.

Suvanto, S., Peltoniemi, M., Tuominen, S., Strandström, M. and Lehtonen, A., 2019. High-resolution mapping of forest vulnerability to wind for disturbance-aware forestry. Forest Ecology and Management, 453, https://doi.org/10.1016/j.foreco.2019.117619.

Suvanto, S., Lehtonen, A., Nevalainen, S., Lehtonen, I., Viiri, H., Strandström, M. and Peltoniemi, M. 2021. Mapping the probability of forest snow disturbances in Finland. Preprint available https://doi.org/10.1101/2020.12.23.424139. 
Vajda, A., Venäläinen, A., Suomi, I., Junila, P. and Mäkelä, H., 2014. Assessment of forest fire danger in a boreal forest environment: description and evaluation of the operational system applied in Finland. Meteorol. Appl., 21: 879-887, DOI: 10.1002/met.1425.

Valta, H., Lehtonen, I., Laurila, T., Venäläinen, A., Laapas, M. and Gregow, H., 2019. Communicating the amount of windstorm induced forest damage by the maximum wind gust speed in Finland. Adv. Sci. Res., 16, 31-37, 2019, https://doi.org/10.5194/asr-16-31-2019.

Venäläinen, A., Laapas, M., Pirinen, P., Horttanainen, M., Hyvönen, R., Lehtonen, I., Junila, P., Hou, M., Peltola, H., 2017. Estimation of the high-spatial-resolution variability in extreme wind speeds for forestry applications. Earth Syst. Dynam. 8(3): 529-545.

Venäläinen, A., Lehtonen, I., Laapas, M., Ruosteenoja, K., Tikkanen, O.-P., Viiri, H., Ikonen, V.-P- and Peltola, H., 2020. Climate change induces multiple risks to boreal forests and forestry in Finland: A literature review. Glob Change Biol. 2020 26:4178-4196. https://doi.org/10.1111/gcb.15183.

Wdowin, J. and Diepeveen, S. 2020. The Value of Data. Bennet Institute for Public Policy. 
FINNISH METEOROLOGICAL INSTITUTE

Erik Palménin aukio 1

P.O. Box 503

FI-00560 HELSINKI

tel. +358295391000

\section{WWW.FMI.FI}

FINNISH METEOROLOGICAL INSTITUTE

RAPORTTEJA-RAPORTER-REPORTS 2021:1 ISSN 0782-6079

ISBN 978-952-336-132-4 (paperback)

ISBN 978-952-336-131-7 (pdf)

https://doi.org/10.35614/isbn.9789523361317
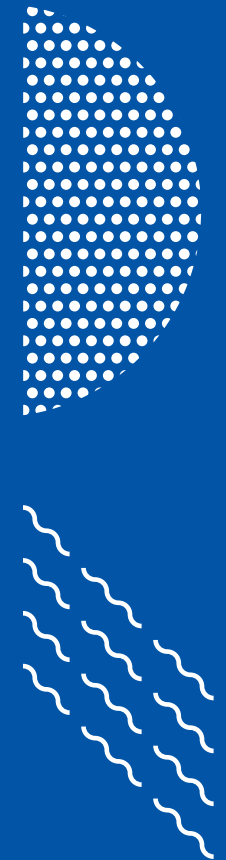

:००:

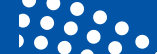

